\title{
Environmental Assessment for Use of DOE-Owned High-Assay Low-Enriched Uranium Stored at Idaho National Laboratory
}

John S Irving

January 2019

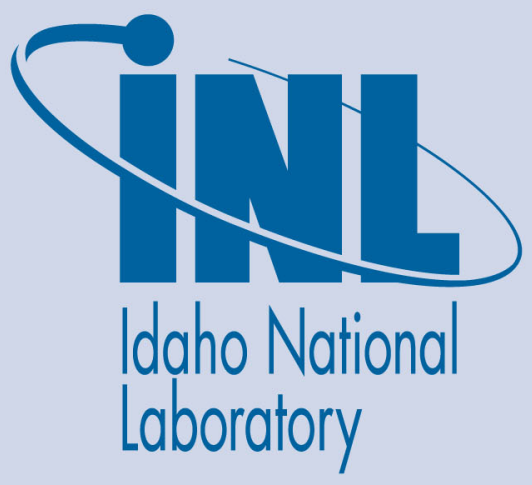

The INL is a U.S. Department of Energy National Laboratory operated by Battelle Energy Alliance 


\section{Environmental Assessment for Use of DOE-Owned High-Assay Low-Enriched Uranium Stored at Idaho National Laboratory}

John S Irving

January 2019

Idaho National Laboratory Idaho Falls, Idaho 83415

http://www.inl.gov

Prepared for the

U.S. Department of Energy

Under DOE Idaho Operations Office

Contract DE-AC07-05ID14517 


\section{Department of Energy}

Idaho Operations Office

1955 Fremont Avenue

Idaho Falls, ID 83415

January 10, 2019

SUBJECT: Final Environmental Assessment for the Use of Department of Energy-Owned High-Assay Low-Enriched Uranium Stored at Idaho National Laboratory (CLN190431)

Dear Citizen:

The United States Department of Energy (DOE) has completed the Final Environmental Assessment (EA) for the Use of Department of Energy-Owned High-Assay Low-Enriched Uranium Stored at Idaho National Laboratory and has determined that a Finding of No Significant Impact (FONSI) is appropriate for the proposed action. The draft EA was made available for a 30-day public review and comment period on October 31, 2018. DOE considered all comments received before finalizing the EA and making the FONSI determination. A Comment Response section is included as Appendix $\mathrm{A}$ in the final EA.

The FONSI and final EA can be accessed on the DOE website at www.id.doe.gov. Thank you for your interest in this important endeavor.

Sincerely,



Manager 



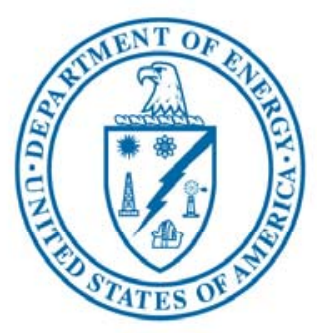

U.S. Department of Energy

Idaho Operations Office

\section{Environmental Assessment for Use of DOE-Owned High-Assay Low-Enriched Uranium Stored at I daho National Laboratory}

Final

January 2019

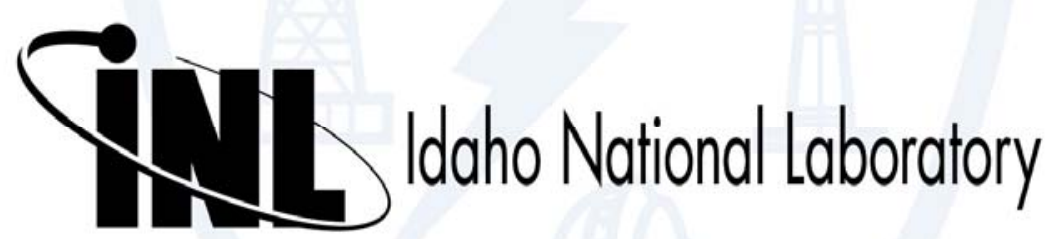





\section{U.S. DEPARTMENT OF ENERGY FINDING OF NO SIGNIFICANT IMPACT FOR THE ENVIRONMENTAL ASSESSMENT FOR USE OF DOE-OWNED HIGH-ASSAY LOW- ENRICHED URANIUM STORED AT IDAHO NATIONAL LABORATORY}

Agency: U.S. Department of Energy (DOE)

Action: Finding of No Significant Impact (FONSI)

Summary: The U. S. Department of Energy (DOE) proposes to make about 10 Metric Tons (MT) of High-Assay Low-Enriched Uranium (HALEU) produced through the electrometallurgical treatment (EMT) process, and other small quantities of HALEU stored at Idaho National Laboratory (INL) available for research development \& demonstration in support of the commercial nuclear industry and government agencies, including use in advanced reactors. $H A L E U$ is a term applied to uranium that is enriched in the uranium-235 (U-235) isotope to a value that is $5 \%$ to $20 \%$ of the total uranium. Private sector advanced nuclear reactor designs and advanced nuclear fuel designs call for use of $H A L E U$, but currently no commercial facility manufactures $H A L E U$.

DOE proposes to expand the fuel fabrication capability at INL to produce up to $10 \mathrm{MT}$ of HALEU fuel at INL to meet near term needs. The production requires expansion of the fuel fabrication capability, including the purchase of new equipment and use of facilities at INL's Materials and Fuels Complex (MFC) and possibly also Idaho Nuclear Technology and Engineering Center (INTEC). DOE would address decisions on the construction and operation of a reactor using the HALEU fuel in future National Environmental Policy Act (NEPA) documents.

INL is the only location considered for the proposed action alternatives and for the no-action alternative because DOE is producing and storing this HALEU feedstock at INL facilities. INL has the available facilities and process knowledge needed to carry out the proposed or no-action alternatives. The proposed action is consistent with INL's mission as the DOE's lead laboratory for nuclear energy research and development.

DOE identified the following alternatives for analysis in this EA:

Alternative 1: Proposed Action - Use of DOE-Owned High-Assay Low-Enriched Uranium Stored at Idaho National Laboratory and expansion of fuel fabrication capability at INL to produce up to $10 \mathrm{MT}$ of HALEU fuel at INL.

- Alternative 1a: Conduct activities only at MFC

- Alternative 1b: Conduct activities at MFC and INTEC

Alternative 2: No action. Under the No Action Alternative, DOE would continue to electrometallurgically treat the EBR-II spent nuclear fuel (about 25 metric tons) and miscellaneous small lots of sodium bonded spent nuclear fuel. DOE would continue to treat the fuel at MFC, blend with depleted uranium if needed to reduce the enrichment levels, and cast into ingots to store until deciding on appropriate disposition made through a future NEPA review. 
Analysis: Based on the analyses in the EA, the proposed action will not significantly affect the human environment within the meaning of the NEPA.

The term "significantly" and the significance criteria are defined by Council on Environmental Quality Regulations for implementing NEPA at 40 CFR 1508.27. The significance criteria relevant to Alternative 1 are addressed and the applicable corresponding analyses in the EA are referenced below.

1.) Beneficial and adverse impacts (40 CFR 1508.27 (b) (1)]: The concentrations of radioactive emissions from normal operations and accidents were calculated by modeling and are below accepted standards, and the impacts are predicted to be negligible. Potential impacts to soil, groundwater, biological resources, sustainability, waste generation, transportation, and nonradiologic air emissions were fully analyzed.

The proposed action could impact historic properties at MFC or INTEC. Since decisions have not been finalized on which buildings will be utilized for HALEU fuel production at these facilities, analysis of potential cultural resource impacts to historical buildings has been deferred, as agreed to by an MOA with the Idaho State Historic Preservation Office (SHPO). This agreement stipulates that DOE and SHPO will work together to ensure that historical siting decisions will be analyzed and impacts mitigated.

The analyses demonstrated that there will be no significant impacts from implementing the proposed action. (section 4)

2.) Public health and safety [40 CFR 1508.27 (b) (2)]: During normal operations, radioactive particulate matter and gaseous emissions are possible. Potential impacts to public and worker health and safety from normal operations and accident scenarios were analyzed, with potential emissions conservatively estimated using the maximum amount of feedstock material to be processed annually and appropriate emission factors based on the physical state of the material. The results convey that conservatively estimated potential radiation doses and latent cancer fatality risks are well below established standards. DOE will implement engineered and administrative controls to further ensure safety and to minimize the potential for environmental consequences during operations. Design features will be augmented by operational requirements and administrative controls to ensure operating parameters are not exceeded. (section 4)

3.) Unique characteristics of the geographical area [40 CFR 1508.27 (b) (3)]: The Eastern Snake River Plain Aquifer underlies the facility location at INL. The potential for impacts to the aquifer from the proposed action during normal operations is not credible. In the unlikely event of an accident with releases, any contaminated soil areas would be secured, remediated and mitigated. INL is comprised of areas of pristine and protected sagebrush steppe ecosystem that provides significant habitat for large numbers of native vegetation and wildlife species, and INL encompasses significant historic and cultural resources. Implementing the proposed action will not result in any direct impacts to these areas, species or resources. (section 3/section 4) 


\begin{abstract}
4.) Degree to which effects on the quality of the human environment are likely to become highly controversial [40 CFR 1508.27 (b) (4)]: DOE used state-of-the-art scientific methods, technology, and qualified experts to assure the accuracy and quality of the impacts analyses and to provide confidence in the results of this assessment. There are no substantive technical or scientific issues related to the proposed action that are not understood, quantified and validated. Since the impacts to the quality of the human environment were determined to be negligible, DOE has made a Finding of No Significant Impact. Comments received from the public challenging DOE's analysis have been substantively resolved. All comments and responses are documented in Appendix A of the Environmental Assessment.
\end{abstract}

5.) Uncertain or unknown risks on the human environment [40 CFR 1508.27 (b) (5)]: The risks associated with the proposed action are well-defined. Fuel fabrication at INL has an extensive history of safe operations, demonstrating limited uncertainty in relation to implementing the proposed action. Nonetheless, all resource areas were screened and carefully analyzed before critical areas were identified for detailed analysis in the EA. All analyses used accepted methodologies and input values and were based on conservative assumptions to ensure the results adequately bounded the potential impacts to human health and the environment.

6.) Precedent for future actions [40 CFR 1508.27 (b) (6)]: The proposed action does not set a precedent for future actions with significant effects nor does it represent a decision in principle about a future consideration on the INL.

7.) Cumulatively significant impacts [40 CFR 1508.27 (b) (7)]: The calculated impacts to the critical resource areas from implementing the preferred alternative were individually insignificant. The additive impacts from implementing the proposed action to those manifested from past, ongoing or reasonably foreseeable future projects or programs on and adjacent to the INL were evaluated and also determined to be insignificant. (section 4.1.6)

8.) Effect on cultural or historic resources [40 CFR 1508.27 (b) (8)]: The proposed action would not disturb areas outside facility areas, but could impact historic properties at MFC or INTEC. INL has not determined which buildings at either MFC or INTEC would be used under the proposed action, so DOE has chosen to defer Section 106, per 36 CFR 800.14(b)(1)(ii), until after a NEPA decision has been made.

DOE negotiated a process for deferment of Section 106 under the proposed action with the Idaho State Historic Preservation Office (SHPO) which involves preparation and signing of a Memorandum of Agreement (MOA) outlining how the Section 106 process will be completed, once determinations are made regarding the specific buildings involved in the proposed action.

The stipulations outlined in the MOA that DOE must meet are:

a. The Section 106 process will begin once the Project scope and description has been finalized.

b. The Project will be responsible for funding the Section 106 process.

c. INL Cultural Resource Management Office (CRMO) staff Architectural Historian meeting the Secretary of the Interior's Professional Qualification Standards for Architectural History will complete the Section 106 process. 
d. Completion of the Section 106 process will include:

i. Survey of proposed project area and identification of Area of Potential Effect (APE);

ii. Identification of historic properties within the APE;

iii. Evaluation of potential effects - immediate and cumulative direct and indirect - to historic properties from project activities.

iv. Adverse Effects will be mitigated as identified in the INL Cultural Resource Management Plan, which may require consultation and concurrence between DOE-ID, the Shoshone-Bannock Tribes and the Idaho SHPO.

9.) Violation of Federal, State or local law [40 CFR 1508.27 (b) (10)]: DOE is confident that implementation of the proposed action does not pose any potential for a violation of any law. The DOE regulatory compliance history at the INL site demonstrates a progressive and comprehensive compliance posture and the results of regulatory oversight activities affirms the existence of a strong environmental, safety and health culture. (section 5)

Determination: Based upon the analysis presented in the attached EA, I have determined that the proposed action would not significantly affect the quality of the human environment. Therefore preparation of an environmental impact statement is not required.

Issued at Idaho Falls, Idaho on this $10^{\text {th }}$ day of January, 2019

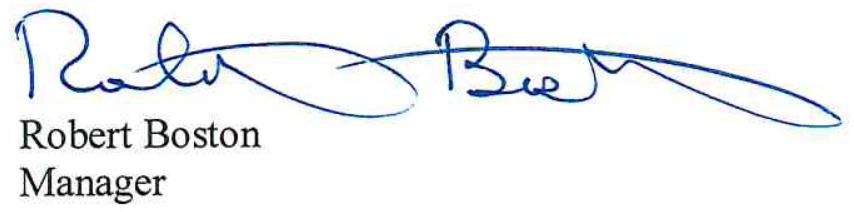

Copies of the EA and FONSI are available from: Tim Jackson, Office of Communications, MS1203, Idaho Operations Office, U.S. Department of Energy, 1955 Fremont Avenue, Idaho Falls, ID 83415 , or by calling $208526-8484$.

For further information on the NEPA process contact: Jason Sturm, NEPA Compliance Officer, MS-1216, U.S. Department of Energy, 1955 Fremont Avenue, Idaho Falls, ID 83415, or by calling 208 526-2493. 


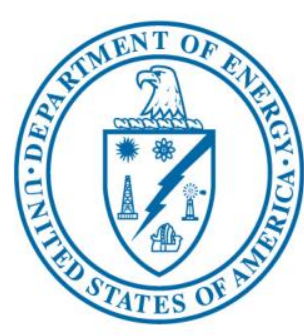

U.S. Department of Energy

Idaho Operations Office

\section{Environmental Assessment for Use of DOE-Owned High-Assay Low-Enriched Uranium Stored at Idaho National Laboratory}

Final

January 2019

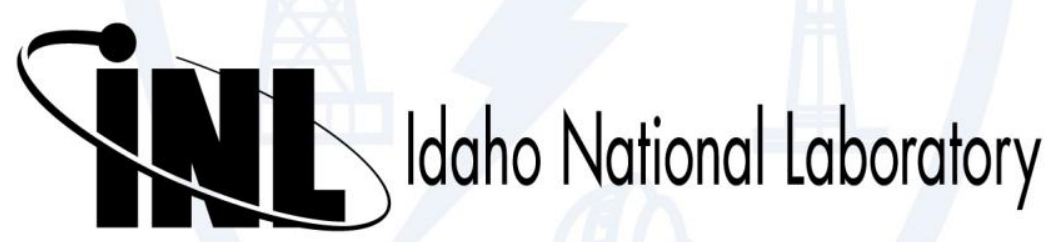





\section{Environmental Assessment for Use of DOE- Owned High-Assay Low-Enriched Uranium Stored at Idaho National Laboratory}

Final

January 2019

U.S. Department of Energy

DOE Idaho Operations Office 


\section{CONTENTS}

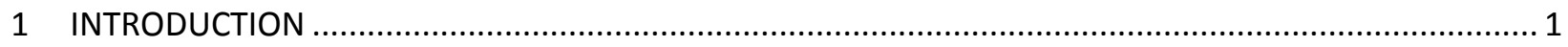

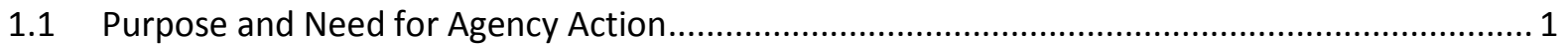

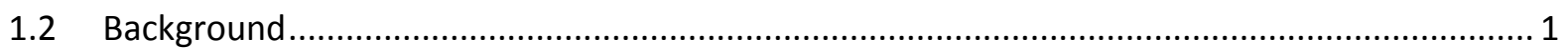

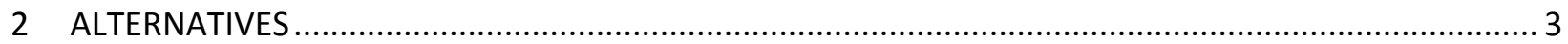

2.1 Alternative 1: Proposed Action -- Use of DOE-Owned High-Assay Low-Enriched

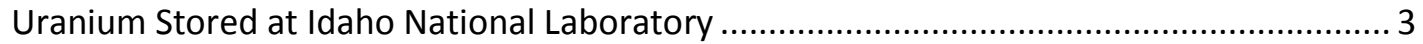

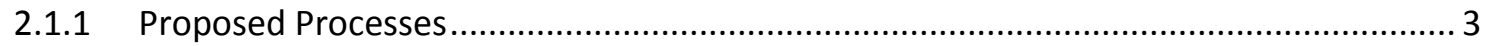

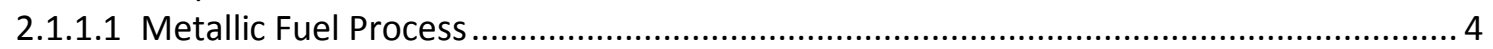

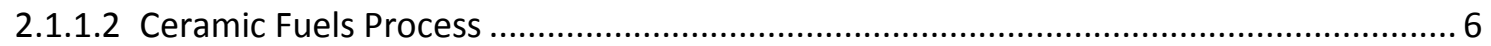

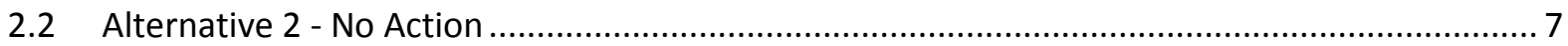

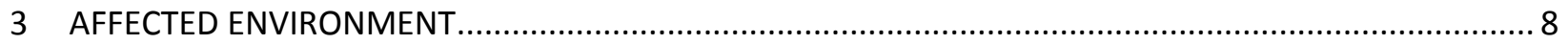

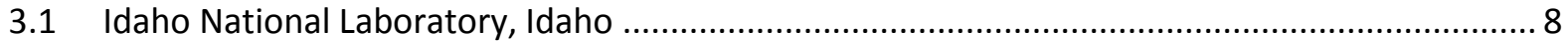

3.1.1 General Description of INL Site and Surrounding Area .............................................. 8

3.1.2 MFC Area (Area Potentially Affected by Alternative 1a and 1b)................................. 10

3.1.3 INTEC Area (Area Potentially Affected By Alternative 1b) ......................................... 10

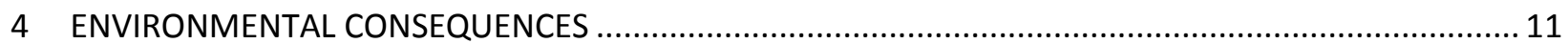

4.1 Alternative 1 - Proposed Action: Use of DOE-Owned High-Assay Low-Enriched

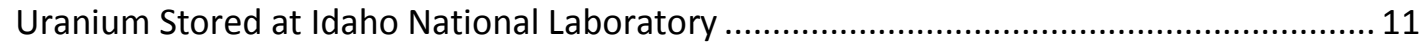

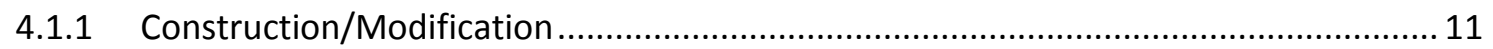

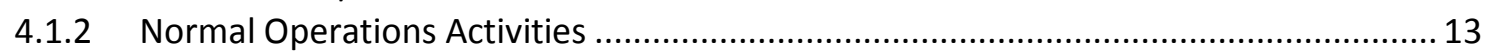

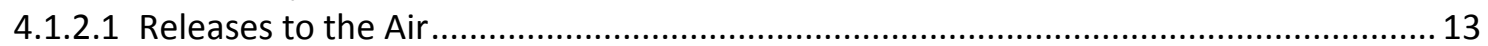

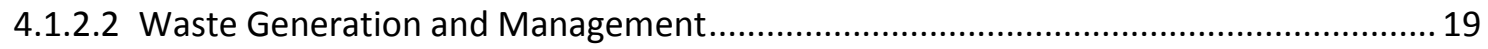

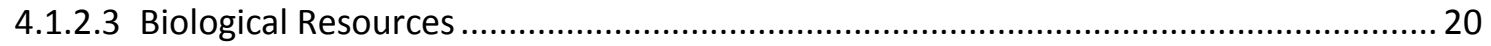

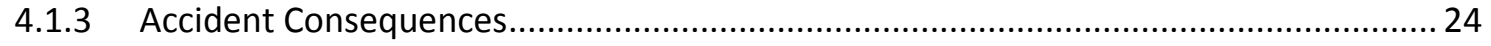

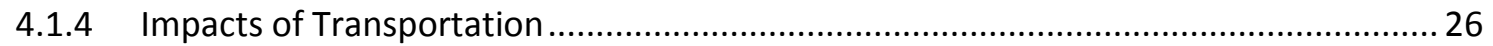





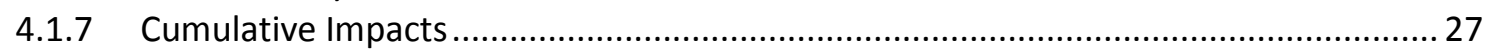

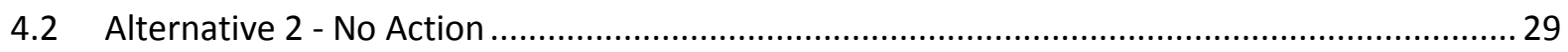

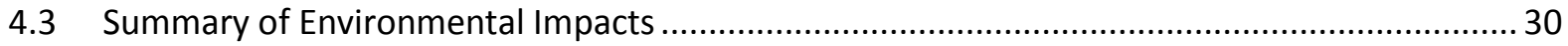

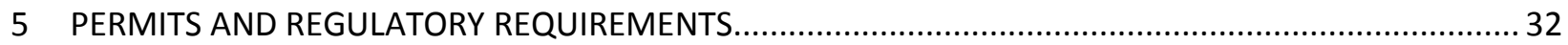

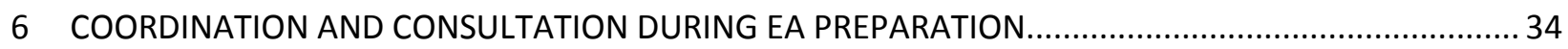

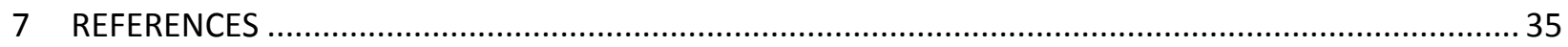

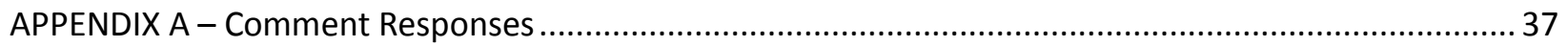




\section{LIST OF FIGURES}

Figure 1. Figure shows the INL Site and the surrounding region with two insets showing locations of MFC and INTEC.

Figure 2. Actual and hypothetical public receptor locations for the air pathway analysis showing distance and direction from MFC and INTEC. Regulatory dose limits do not apply to the nearest boundary

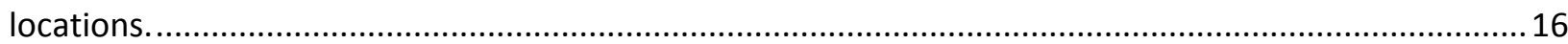

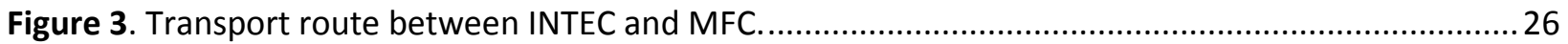

\section{LIST OF TABLES}

Table 1. Radionuclide inventory in 2,500 kg HALEU feedstock material and unabated estimated annual potential to emit per processing facility. 15

Table 2. Public air pathway potential dose estimates from normal operations (unmitigated dose).........17

Table 3. Collocated worker potential doses from operational radionuclide emissions (unmitigated dose).

Table 4. Comparison of maximum radionuclide soil concentrations to EPA PRGs.

Table 5. Results of Level 1 RESRAD-BIOTA analysis of proposed HALEU releases at MFC (Alternative 1a). Terrestrial animals are the limiting organism.

Table 6. Results of Level 1 RESRAD-BIOTA analysis of proposed HALEU releases at INTEC (Alternative $1 b$ ). Terrestrial animals are the limiting organism.

Table 7. Summary of dose impacts for the highest consequence events for Alternative 1

Table 8 Estimated annual air pathway dose (mrem) from normal operations to the maximally exposed off-site individual from the above proposed projects, including the estimated dose from HALEU fuel production.

Table 9. Summary of environmental impacts. ${ }^{a}$ 30 


\section{ACRONYMS}

\begin{tabular}{|c|c|c|c|}
\hline APAD & $\begin{array}{l}\text { air permitting applicability } \\
\text { determination }\end{array}$ & $\begin{array}{l}\text { LCF } \\
\text { LLW }\end{array}$ & $\begin{array}{l}\text { latent cancer fatality } \\
\text { low-level waste }\end{array}$ \\
\hline ATC & approval to construct & MEI & maximally exposed individual \\
\hline ATR & Advanced Test Reactor & MOA & memorandum of agreement \\
\hline CAA & Clean Air Act & MFC & Materials and Fuels Complex \\
\hline CFR & Code of Federal Regulations & MLLW & mixed low-level waste \\
\hline $\begin{array}{l}\text { DOE } \\
\text { DOE-ID }\end{array}$ & $\begin{array}{l}\text { U.S. Department of Energy } \\
\text { U.S. Department of Energy - Idaho } \\
\text { Operations Office }\end{array}$ & NESHAPS & $\begin{array}{l}\text { National Emissions Standards for } \\
\text { Plutonium- } 239 \text { equivalent Hazardous } \\
\text { Air Pollutants }\end{array}$ \\
\hline & environmental assessment & NEPA & National Environmental Policy Act \\
\hline ECAR & engineering calculations and analysis & $\begin{array}{l}\text { NHPA } \\
\text { NRC }\end{array}$ & $\begin{array}{l}\text { National Historic Preservation Act } \\
\text { U.S. Nuclear Regulatory Commission }\end{array}$ \\
\hline ED & $\begin{array}{l}\text { report } \\
\text { effective dose }\end{array}$ & NRHP & National Register of Historic Places \\
\hline EIS & environmental impact statement & NSR & new source review \\
\hline EMT & electrometallurgical treatment & PRGs & preliminary remediation goals \\
\hline EPA & U.S. Environmental Protection Agency & ppm & parts per million \\
\hline FR & Federal Register & PTC & permit to construct \\
\hline $\begin{array}{l}\text { GHG } \\
\text { GTCC }\end{array}$ & $\begin{array}{l}\text { greenhouse gas } \\
\text { Greater Than Class C }\end{array}$ & $\begin{array}{l}\text { REM } \\
\text { ROD } \\
\text { RSAC }\end{array}$ & $\begin{array}{l}\text { roentgen equivalent man } \\
\text { record of decision } \\
\text { Radiological Safety Analysis Computer }\end{array}$ \\
\hline HALEU & High-Assay Low-Enriched Uranium & & Program \\
\hline $\begin{array}{l}\text { HEPA } \\
\text { HLW }\end{array}$ & $\begin{array}{l}\text { High Efficiency Particulate Air } \\
\text { High-Level Waste }\end{array}$ & SHPO & State Historic Preservation Office \\
\hline INL & Idaho National Laboratory & TED & total effective dose \\
\hline INTEC & Idaho Nuclear Technology and & USC & U.S. Code \\
\hline
\end{tabular}




\section{HELPFUL INFORMATION FOR THE READER}

\section{Scientific Notation}

This document uses scientific notation to express numbers that are very small or very large. A number with a negative exponent, such as $1.3 \times 10^{-6}$ is a very small number. To convert this small number to the more commonly used decimal notation, move the decimal point left by the number of places equal to the exponent, in this case 6 . The number thus becomes 0.0000013 . For large number, those with a positive exponent, move the decimal point to the right by the number of places equal to the exponent. For instance, the number 1,300,000 becomes $1.3 \times 10^{6}$. This document also uses 'E notation' for small numbers: Numbers less than 1 will have a negative exponent. For instance, a millionth of a second is: $0.000001 \mathrm{sec}$. or $1.0 \mathrm{E}-6$ or $1.0^{\wedge}-6$ or $10 \times 10^{-6}$.

\section{Units}

This document uses English units with conversion to metric units given below. Occasionally, metric units are used if metric is the common usage (i.e., when discussing waste volumes or when commonly used in formulas or equations).

\begin{tabular}{ll|ll|ll}
$\mathrm{cal} / \mathrm{g}$ & calories per gram & $\mathrm{J} / \mathrm{g}$ & joule per gram & $\mathrm{mrem}$ & millirem \\
$\mathrm{cfm}$ & cubic feet per minute & $\mathrm{km}$ & kilometers & $\mathrm{MT}$ & metric ton \\
$\mathrm{cm}$ & centimeters & $\mathrm{kW}$ & kilowatt & $\mathrm{rem}$ & roentgen-equivalent-man \\
$\mathrm{ft}$ & foot (feet) & $\mathrm{m}$ & meter & $\mathrm{pCi} / \mathrm{g}$ & picocurie per gram \\
$\mathrm{GSF}$ & gross square $\mathrm{ft}$ & $\mathrm{mi}$ & mile & $\mathrm{T}$ & ton(s) \\
$\mathrm{in}$. & inch & $\mathrm{mi}^{2}$ & square $\mathrm{mi}$ & $\mathrm{yr}$ & year
\end{tabular}

\section{Conversions}

\begin{tabular}{|c|c|c|c|c|c|}
\hline \multicolumn{3}{|c|}{ English to Metric } & \multicolumn{3}{|c|}{ Metric to English } \\
\hline To Convert & Multiply By & To Obtain & To Convert & Multiply By & To Obtain \\
\hline acres & $4.047 \times 10^{-1}$ & hectares & hectares & 2.471 & acres \\
\hline $\mathrm{ft} / \mathrm{sec}$ & $3.048 \times 10^{1}$ & $\mathrm{~cm} / \mathrm{sec}$ & $\mathrm{cm} / \mathrm{sec}$ & $3.281 \times 10^{-2}$ & $\mathrm{ft} / \mathrm{sec}$ \\
\hline $\mathrm{ft}$ & $3.048 \times 10^{-1}$ & $\mathrm{~m}$ & $\mathrm{~m}$ & 3.28084 & feet \\
\hline gallons & 3.785 & liters & liters & $2.641 \times 10^{-1}$ & gallons \\
\hline $\mathrm{mi}$ & 1.609334 & $\mathrm{~km}$ & $\mathrm{~km}$ & $6.214 \times 10^{-1}$ & $\mathrm{mi}$ \\
\hline square mi & 2.590 & square km & square km & $3.861 \times 10^{-1}$ & square mi \\
\hline $\mathrm{lb}$ & 0.453592 & $\mathrm{~kg}$ & $\mathrm{~kg}^{1}$ & 2.205 & $\mathrm{lb}$ \\
\hline $\mathrm{T}$ & $9.08 \times 10^{-1}$ & MT & $\mathrm{MT}^{1}$ & 1.1013 & $\mathrm{~T}$ \\
\hline yards & $9.144 \times 10^{-1}$ & $\mathrm{~m}$ & $\mathrm{~m}$ & 1.093613 & yards \\
\hline
\end{tabular}

\footnotetext{
${ }^{1}$ Note: $1000 \mathrm{~kg}$ equals a Metric Ton (MT)
} 


\section{Understanding Small and Large Numbers}

\begin{tabular}{lll}
\multicolumn{1}{c}{ Number } & Power & Name \\
\hline $1,000,000,000,000,000$ & $=10^{15}$ & quadrillion \\
$1,000,000,000,000$ & $=10^{12}$ & trillion \\
$1,000,000,000$ & $=10^{9}$ & billion \\
$1,000,000$ & $=10^{6}$ & million \\
1,000 & $=10^{3}$ & thousand \\
10 & $=10^{1}$ & ten \\
0.1 & $=10^{-1}$ & tenth \\
0.01 & $=10^{-2}$ & hundredth \\
0.001 & $=10^{-3}$ & thousandth \\
0.000001 & $=10^{-6}$ & millionth \\
0.000000001 & $=10^{-9}$ & billionth \\
0.000000000001 & $=10^{-12}$ & trillionth \\
0.000000000000001 & $=10^{-15}$ & quadrillionth
\end{tabular}




\section{Understanding Dose (Millirem Doses) and Latent Cancer Fatality}

\section{Relative Doses ${ }^{1}$}

A dose is the amount of radiation energy absorbed by the body. The United States unit of measurement for radiation dose is the rem (Roentgen Equivalent Man). In the U.S., doses are most commonly reported in millirem (mrem). A millirem is one thousandth of a rem (1000 mrem $=1$ rem). The inset diagram compares radiation doses from common radiation sources, both natural and man-made. Use this information to help understand and compare dose information described in this document.

\section{Latent Cancer Fatality calculations}

The consequence of a dose to an individual is expressed as the probability that the individual would incur fatal cancer from the exposure. Based on a dose-to-risk conversion factor of 0.00041 latent cancer fatality (LCF) per person-rem), and assuming the linear nothreshold model, an exposed worker receiving a dose of 1 rem would have an estimated lifetime probability of radiation-induced fatal cancer of 0.00041 or 1 chance in 2,400 .

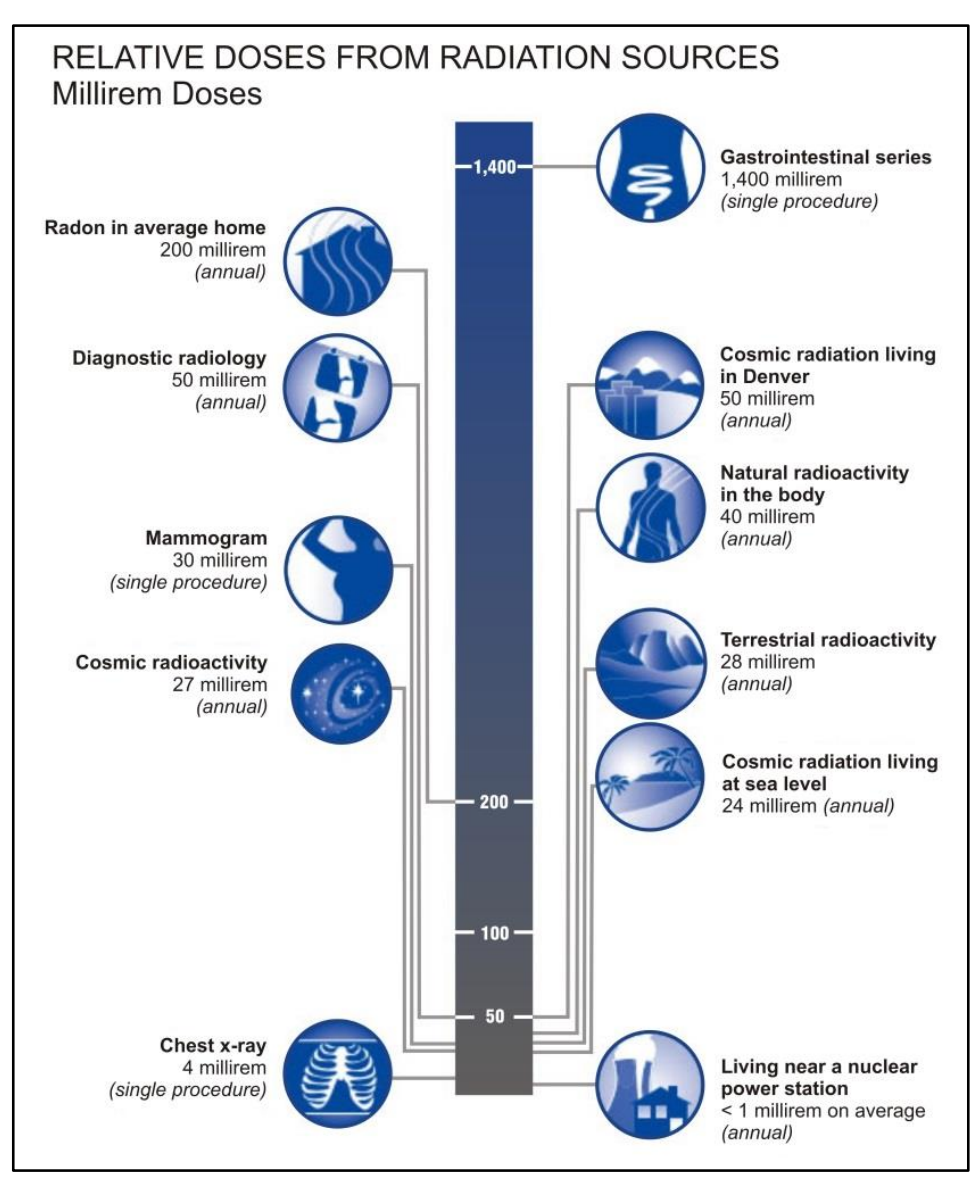

${ }^{1}$ From http://www.epa.gov/radiation/understand/perspective.html 


\section{GLOSSARY}

Note: Terms in this Glossary are italicized in the text.

Attainment area: An area considered to have air quality as good as or better than the National Ambient Air Quality Standards as defined in the Clean Air Act (CAA). An area may be an attainment area for one pollutant and a nonattainment area for others.

Cladding: The outer layer of a nuclear fuel rod, which is located between the coolant or test environment and nuclear fuel. Cladding prevents radioactive elements from escaping the fuel into the coolant or test environment and contaminating it.

Clean Air Act (CAA): The Federal CAA is the basis for the national air pollution control effort. Basic elements of the act include National Ambient Air Quality Standards for major air pollutants, hazardous air pollutants, state attainment plans, motor vehicle emission standards, stationary source emission standards and permits, acid rain control measures, stratospheric ozone protection, and enforcement provisions.

Cultural resource: A broad term for buildings, structures, sites, districts, or objects of significance in American history, architecture, archaeology, engineering, or culture which are identifiable through field inventory, historical documentation, or oral evidence. Cultural resources may be, but are not necessarily, eligible for nomination to the National Register of Historic Places (NRHP) (see entry for historic property).

Dose consequences: The dose is the consequence of a person exposed to ionizing radiation. The increased chance of a person getting a cancer, as a result of exposure to a dose, is a risk-based consequence. If the dose is high enough, there is a chance the dose would result in a LCF. Collectively, dose, chance of getting a cancer, and risk of a LCF occurrence is the dose consequence.

Effective dose (ED): The sum of the products of the dose equivalent received by specified tissues of the body and a tissue-specific-weighting factor. This sum is a risk-equivalent value and used to estimate the health-effects risk of the exposed individual. The tissue-specific-weighting factor is the fraction of the total health risk resulting from uniform whole-body irradiation contributed by that particular tissue.

The effective dose, or ED, includes the committed ED from internal radionuclides deposition and the doses from penetrating radiation sources external to the body. The ED is expressed in units of rem. The U.S. Environmental Protection Agency (EPA) regulations in 40 Code of Federal Regulations (CFR) Part 61, Subpart H specify that estimates of radiological dose to a member of the public be reported in terms of effective dose equivalent or total ED equivalent, consistent with an older methodology described in International Commission on Radiological Protection (ICRP) Publication 26 (ICRP 1977) and ICRP Publication 30 (ICRP 1979-1988).

Fast-Spectrum Reactor: Nuclear reactor with minimal slowing down (moderation) of fission neutrons to lower energies. Such reactors use coolants other than water, which slows down neutrons, and those coolants provide some safety advantages. Fast-spectrum reactor also have advantages for managing the long-term fuel cycle and reducing long-lived constituents of high-level waste (HLW).

Fuel rod: Individual units of coated or clad nuclear fuel.

Glovebox: A controlled environment work enclosure, of rigid construction, that serves as a primary barrier from the work area. Operations are performed through sealed glove openings to protect the worker, the work environment and the product. 
Greater-than-class C (GTCC) Low level radioactive waste (LLRW). GTCC LLRW has radionuclide concentrations exceeding the limits for Class C LLRW established by the U.S. Nuclear Regulatory Commission (NRC). These wastes are generated by activities licensed by the NRC or Agreement States and cannot be disposed of in licensed commercial LLRW disposal facilities.

HALEU: High Assay Low Enriched ( $U^{235}$ content ranges from $>5 \%$ to $<20 \%$ ) Uranium. The term may be further broken out into the following:

HALEU feedstock: The nuclear material that has been processed by Fuel Conditioning Facility and is being used as feedstock for the fuel fabrication process described in this document.

HALEU fuel: The final fuel produced using the HALEU feedstock.

Hazard Category 2 nuclear facility: A nuclear facility that is allowed a significant quantity of special nuclear material as defined in DOE-STD-1027-92 (1997 Change notice).

High-level waste (HLW): High-level waste is the highly radioactive waste material resulting from the reprocessing of spent nuclear fuel, including liquid waste produced directly in reprocessing and any solid material derived from such liquid waste that contains fission products in sufficient concentrations; and other highly radioactive material that is determined, consistent with existing law, to require permanent isolation. [Adapted from: Nuclear Waste Policy Act of 1982, as amended]

Historic property: Any prehistoric or historic district, site, building, structure, or object included in, or eligible for inclusion in, the NRHP.

Hot cell: Shielded containment chambers used to protect workers from radiation by creating a safe containment area in which workers can control and manipulate the equipment required.

Hydride-dehydride: A process used to make ceramic powder from metal uranium. The first step exposes uranium metal to flowing hydrogen gas at elevated temperature (roughly $230^{\circ} \mathrm{C}$ ) to form uranium hydride, which breaks up the bulk metal into a powder. The second step exposes the uranium hydride powder to a vacuum at increased temperature (e.g., $400^{\circ} \mathrm{C}$ ), which decomposes the uranium hydride into metal powder and hydrogen gas. The metal powder can then be exposed to nitrogen to form uranium nitride.

Latent cancer fatality (LCF): Based on the Linear no-threshold model, the value reported as an LCF is the risk that a death results from a dose sustained. (See Helpful Information for the Reader).

Linear no-threshold model: The hypothesized model that assumes that additional cancer risk to persons exposed to ionizing radiation is linear and proportional with respect to the absorbed dose, and becomes zero only at zero dose.

Low-level waste. Low-level radioactive waste is radioactive waste that is not high level radioactive waste, spent nuclear fuel, transuranic waste, byproduct material (as defined in section 11e.(2) of the Atomic Energy Act of 1954, as amended), or naturally occurring radioactive material. [Adapted from: Nuclear Waste Policy Act of 1982, as amended].

Mixed waste. Waste that contains both source, special nuclear, or by-product material subject to the Atomic Energy Act of 1954, as amended, and a hazardous component subject to the Resource Conservation and Recovery Act. [Adapted from: Federal Facility Compliance Act of 1992]

National Ambient Air Quality Standards: Standards established by the Environmental Protection Agency (EPA) under authority of the CAA that apply to outdoor air throughout the country. Primary standards protect human health with an adequate margin of safety, including sensitive populations (such as children, the elderly, and individuals suffering from respiratory disease). Secondary standards protect public welfare from any known or anticipated adverse effects of a pollutant. 
National Emissions Standards for Hazardous Air Pollutants (NESHAPs): The CAA requires the EPA to regulate airborne emissions of hazardous air pollutants (including radionuclides) from a specific list of industrial sources called "source categories." Each "source category" that emits radionuclides in significant quantities must meet technology requirements to control hazardous air pollutants and is required to meet specific regulatory limits.

New Source Review (NSR): EPA's permitting program that protects air quality when factories, industrial boilers and power plants are newly built or modified. NSR permitting also assures that new or modified industries are as clean as possible, and advances in pollution control occur concurrently with industrial expansion.

Nitride-denitride: A process used to make uranium nitride powder from metal uranium powder. The first step exposes uranium metal powder to flowing nitrogen gas as the temperature is raised to $800^{\circ} \mathrm{C}$, forming $\mathrm{U}_{2} \mathrm{~N}_{3}$, and UN. The second step increases the temperature to over $1100^{\circ} \mathrm{C}$ without nitrogen flow to decompose the $\mathrm{U}_{2} \mathrm{~N}_{3}$ powder to UN powder, which is the compound used in uranium nitride fuel.

Nonattainment NSR area: The CAA and its amendments in 1990 define a nonattainment area as a locality where air pollution levels persistently exceed National Ambient Air Quality Standards or that contribute to ambient air quality in a nearby area that fails to meet those standards. The EPA classifies nonattainment areas based on the severity of the violation and the air quality standard they exceed. EPA designations of nonattainment areas are based on violations of national air quality standards for oxides of nitrogen, carbon monoxide, lead, ozone (1-hr), particulate matter (PM-10/PM-2.5), and sulfur oxides.

Nuclear fuel: Coated or clad nuclear material designed and fabricated to be used to power nuclear systems.

Person-rem: A person-rem is a collective radiation dose applied to populations or groups of individuals and is the product of the average dose per person (expressed in rem) times the number of people exposed or the population affected.

Receptor: Any element in the environment (typically human or ecological) which is subject to impacts, usually from exposure to hazardous conditions or substances.

Member of the public (public receptor location or hypothetical member of the public): Location where a member of the public could be when the activity is taking place. "Public receptor locations" correspond to the location of either an actual or a hypothetical person. These receptor locations are used because they correspond to those where the highest dose to a member of the public could occur.

Facility worker: Person working inside a facility when the activity is taking place. These workers could be protected by technical safety requirements, administrative procedures, and personal protective equipment that minimize dose in event of an accident occurring inside a facility. However, doses given in this document do not credit these protective measures.

Collocated worker: Hypothetical person working outside of the facility where the activity is occurring. These workers are less likely to be protected by technical safety requirements, administrative procedures, or personal protective equipment when an accident occurs. The doses calculated for collocated workers do not credit any protective measures that could be put in place.

Crewmember: The driver and passenger of a transportation vehicle.

Residual Fission Products: Fission products (elements/isotopes produced during irradiation) that remain in the HALEU feedstock.

Roentgen Equivalent Man (REM): The United States unit of measurement, REM, is the unit used to express effective dose (ED). REM measures the biologic effects of ionizing radiation. A millirem (mrem) is one thousandth of a rem (0.001 rem), often used to express dosages commonly encountered from medical imaging (X-rays) or natural background sources. 
Vadose zone: A subsurface zone of soil or rock containing fluid under pressure that is less than that of the atmosphere. Pore spaces in the vadose zone are partly filled with water and partly filled with air. The vadose zone is limited by the land surface above and by the water table below.

Thermal-Spectrum Reactor: Nuclear reactor with fission neutrons slowed down (moderated) to energies comparable to the thermal vibrational energy of atoms in the reactor structural materials and fuel. This reactor type includes light water reactors, which are used in the U.S. and elsewhere for producing electricity, heavy water reactors, and gas-cooled reactors.

Transuranic waste (TRU): Transuranic waste is radioactive waste containing more than 100 nanocuries (3700 Becquerels) of alpha-emitting transuranic isotopes per gram of waste, with half-lives greater than 20 years, except for: (1) high-level radioactive waste; (2) waste that the Secretary of Energy has determined, with the concurrence of the Administrator of the Environmental Protection Agency, does not need the degree of isolation required by the 40 CFR Part 191 disposal regulations; or (3) waste that the Nuclear Regulatory Commission has approved for disposal on a case-by-case basis in accordance with 10 CFR Part 61. [Source: WIPP Land Withdrawal Act of 1992, as amended] 


\section{Environmental Assessment for Use of DOE-Owned High-Assay Low-Enriched Uranium Stored at Idaho National Laboratory}

\section{INTRODUCTION}

\subsection{Purpose and Need for Agency Action}

The U.S. Department of Energy (DOE) proposes to make available about 10 Metric Tons (MT) of High-Assay LowEnriched Uranium $\left(H A L E U^{2}\right)$ feedstock produced through the electrometallurgical treatment (EMT) process, and other small quantities of HALEU stored at Idaho National Laboratory (INL) for research development \& demonstration in support of the commercial nuclear industry and government agencies, including use in advanced reactors. HALEU is a term applied to uranium that is enriched in the uranium-235 (U-235) isotope to a value that is $5 \%$ to $20 \%$ of the total uranium. Private sector advanced nuclear reactor designs and advanced nuclear fuel designs call for use of HALEU, but currently no commercial facility manufactures HALEU.

DOE proposes to expand the fuel fabrication capability at INL to produce HALEU fuel at INL from 10 MT of HALEU feedstock to meet near-term needs. The production requires expansion of the fuel fabrication capability, including the purchase of new equipment and use of facilities at INL's Materials and Fuels Complex (MFC) and the Idaho Nuclear Technology and Engineering Center (INTEC). DOE has made no decision on the specific use of the fuel. The fuel could be used in advanced reactor design or for the purpose of research and development. DOE would work with other Federal agencies and commercial vendors to determine use of HALEU fuel. Use of this HALEU, including its potential use in a future nuclear reactor, will be analyzed in future National Environmental Policy Act (NEPA) documents by the appropriate agency.

The EMT process in operation at the INL converts sodium-bonded spent nuclear fuel into waste forms suitable for disposal as high-level waste and a HALEU product that is unsuitable for diversion to nuclear weapons but could be either reused in fuel or disposed of as waste. The Final Environmental Impact Statement for the Treatment and Management of Sodium-Bonded Spent Nuclear Fuel, DOE/EIS-0306, DOE 2000) discussed the EMT process, but did not make a decision on the disposition or use of the HALEU product from the EMT process. This Environmental Assessment (EA) addresses the HALEU product as HALEU feedstock in production of HALEU fuel.

\subsection{Background}

The primary mission of the DOE Office of Nuclear Energy is to advance nuclear power as a resource capable of meeting the Nation's energy, environmental, and national security needs by resolving technical, cost, safety, security barriers, and proliferation concerns through research and development and demonstration. DOE has been exploring how to support deploying advanced reactor technology by the domestic (United States) nuclear industry and the industry interest in using HALEU fuel. HALEU consists of uranium enriched in the isotope U-235 between 5 and 20 percent. $\mathrm{U}-235$ is an isotope of uranium that drives the nuclear reaction. Commercial reactors use fuel typically enriched between 3 and 5 percent. The higher U-235 enrichment in HALEU reactor fuel allows advanced reactors to operate longer before refueling. Public and private interest in advanced reactor technology is considerable because of the technologies potential to supply transportable, reliable, and affordable power.

${ }^{2}$ The Glossary defines Italicized terms. 
DOE's support of advanced reactor development may include making available about $10 \mathrm{MT}$ of HALEU feedstock for use as fuel by the commercial nuclear industry and government agencies for advanced reactor research, development, and demonstration activities. Other applications using HALEU may be of interest to the commercial industry.

Most of the available HALEU at INL is a product of the EMT of sodium-bonded spent nuclear fuel (SNF) that occurs in the Fuel Conditioning Facility at the MFC at INL. DOE's Sodium Bonded Environmental Impact Statement (EIS) discusses the EMT process, DOE/EIS-0306 (DOE 2000). The EMT process involves dissolving SNF rods in molten salt and extracting uranium and transuranic elements through electrolysis, then processing in a metal casting furnace to produce low-enriched uranium ingots. The 2000 Record of Decision (ROD) for DOE/EIS0306 did not make a decision on the disposition of the uranium ingots, instead deciding to store the ingots and deferring a decision on disposition to a separate NEPA review. 


\section{ALTERNATIVES}

The Council on Environmental Quality's NEPA regulations require agencies to identify and assess reasonable alternatives (40 CFR 1500.2[e]) when proposing new activities. In line with this requirement, DOE has reviewed and analyzed two reasonable alternatives, plus a second "No Action" alternative, in this EA.

INL is the only location considered for the proposed action alternatives and for the no-action alternative because DOE is producing and storing the FCF HALEU feedstock at INL facilities. INL has the available facilities and process knowledge needed to carry out the proposed or no-action alternatives. Finally, the proposed action is consistent with INL's mission as the DOE's lead laboratory for nuclear energy.

DOE identified the following alternatives for analysis in this EA:

Alternative 1: Proposed Action - Use of DOE-Owned High-Assay Low-Enriched Uranium Stored at Idaho National Laboratory

- Alternative 1a: Conduct activities only at MFC

- Alternative $1 \mathrm{~b}$ : Conduct activities at MFC and INTEC

Alternative 2: No action.

\subsection{Alternative 1: Proposed Action -- Use of DOE-Owned High-Assay Low- Enriched Uranium Stored at Idaho National Laboratory}

The proposed alternative calls for equipping two INL facilities at MFC or one at MFC and one at INTEC to fabricate each of two fuel types from FCF HALEU feedstock using associated fuel fabrication processes. Specifically, INL proposes a ceramic fuel fabrication process and a metallic fuel fabrication process installed and operated within two respective INL buildings. INL has not determined which buildings would house each of the two fabrication processes. This EA evaluates the potential impacts from developing a ceramic HALEU fuel fabrication operation and a metallic HALEU fuel fabrication operation at the INL. The buildings would be distinct only by the volume of air contained and in location for possible emissions.

The EA identifies only two variants to the proposed action: 1) two buildings located at MFC, and 2) one building at MFC and one building at INTEC. There is no distinction in potential emissions from the two MFC buildings, so the only variant that bears on the environmental impacts is whether one of the buildings is at INTEC.

The 2000 ROD did not make a decision on the disposition and use of the HALEU feedstock from the EMT process. DOE now proposes to use $10 \mathrm{MT}$ of HALEU feedstock produced through the EMT process, and other small quantities of HALEU feedstock stored at INL, to support early-stage demonstration by the commercial nuclear industry and government agencies. The processes need to clean the material of impurities to be useable in industry applications. Uses of the material involve research and development activities and use as nuclear fuel, including for use in advanced reactors.

\subsubsection{Proposed Processes}

The two types of fuels considered in this document are, in general, metallic and ceramic fuels. Ceramic fuels are compounds in which a metal (uranium, in this case) is chemically combined with a non-metal, such as oxygen or nitrogen to form uranium oxide $\left(\mathrm{UO}_{2}\right)$ or uranium nitride $(\mathrm{UN})$, respectively. Metallic fuels are made of uranium alloyed with other elements (typically zirconium) so the fuel retains a metallic form. Most advanced reactor 
designs call for use of one of these two types of fuel. Metallic fuels typically have been used in fast-spectrum reactors with liquid metal coolants, while ceramic fuels have been used in both fast- and thermal-spectrum reactors. Ceramic fuel fabrication is usually performed by synthesizing the ceramic compounds in powder form followed by pressing and sintering of the powders into solid pellets. Metallic fuel fabrication usually begins with melting the fuel constituents together to form an alloy, following which the alloy is immediately, or after solidification and reheating, cast or otherwise shaped to the specific form desired by the specific reactor design. Although the specific steps and details for these fabrication processes vary for specific fuel designs, the processes can be described generically but with enough detail to allow evaluation of bounding environmental impacts. Some design specifics that bear on fabrication details include the means of thermally bonding the fuel material to the enclosing cladding; e.g., some fuel designs use a liquid metal (such as sodium, which is solid at room temperature but liquid at operating reactor temperatures) in the annular space between fuel and cladding, while other fuel designs might use helium in that gap or even eliminate the gap by pressing fuel and cladding together for a mechanical bond. Those details have little impact on the extent of environmental impact, so the fabrication processes for metallic and ceramic fuels are described generically in the following subsections.

The processes described below are based on the following assumptions:

- HALEU feedstock is obtained from Experimental Breeder Reactor-II (EBR-II) fuel processing with the intended U-235 enrichment, contaminated with about 100 parts per million (ppm) transuranic contaminants

- Residual fission products have been removed such that the feedstock can be handled without extensive shielding (i.e., without requiring shielding walls as in hot cells, although containment of low-activity contamination would require gloveboxes)

- The typical batch sizes that would be processed through fuel fabrication would be roughly 30-50 $\mathrm{Kg}$ HALEU feedstock/batch, although this would be limited by criticality safety considerations

- The quantities of fuel assumed to be fabricated would likely require the process be operated within a double-high efficiency particulate air (HEPA) -filtered, Hazard Category 2 nuclear facility. The total target throughput of a fuel fabrication process, either ceramic or metallic, would not exceed $2500 \mathrm{~kg} / \mathrm{year}$. The process lines would be in separate facilities, the total throughput of the two combined facilities would not exceed $5000 \mathrm{~kg} /$ year.

\subsubsection{Metallic Fuel Process}

Typical metallic fuel fabrication processes consist of the following 6 stages: 1) receipt of HALEU feedstock; 2) alloy production; 3 ) fuel casting or forming; 4) final mechanical processing (shearing to length, machining, forming, etc.); 5) encapsulation into cladding to form fuel rods; and 6) final inspections. Any steps involving fuel before being hermetically sealed within a cladding tube would be performed in engineered enclosures (typically gloveboxes). These stages are discussed in further detail below.

HALEU Receiving/Cleaning/Casting: Because the HALEU feedstock is coming from the FCF used fuel treatment process, an initial cleaning step may be necessary. In most cases, this could be a simple external decontamination of the as-received ingots to minimize contamination spread to the gloveboxes. In some cases, depending on the condition of the HALEU feedstock, a mechanical or chemical cleaning may be necessary to 
remove oxide or slag layers. During the cleaning process, waste products would be generated. Following cleaning, the HALEU feedstock is ready for casting. Casting and alloying can be a one- or two-step process. In a single-step process, the HALEU feedstock and other alloying components, such as zirconium, are loaded into a crucible. The crucibles are usually coated with a non-reactive ceramic (typically yttrium oxide). The loaded crucible is placed into a furnace and heated, usually to about $1500^{\circ} \mathrm{C}$ and held for about $1-2$ hours to melt and mix the constituents into a homogeneous alloy. The exact casting temperature used depends on alloy composition and specific process needs. The molten alloy is then poured or injected into a mold of specific shape. In a two-step process, the material is melted and poured into an interim shape, usually sized for convenient handling. The first casting step results in chemical homogeneity and allows inspection for the proper chemical composition. During the second casting step, the product is melted again and cast into the desired final fuel form. Casting operations with molten uranium alloys form an oxide slag or dross. This dross is a waste stream that requires disposal or, preferably, eventual recycle into a new casting batch. Crucibles generally can be re-used for 10-20 cycles; however, the non-reactive coating must be removed and re-applied after each casting process. In the past, single-use quartz molds have been used for solidifying the cast metal into the desired shape, and those molds could be used only a single time before being disposed as waste. Developments in recent years may allow use of re-useable fuel molds, which would reduce the amount of casting process waste.

Mechanical Processing: Industry and research institutions/organizations have communicated interest in a number of metallic fuel forms. Some fuel forms can be geometrically complex, while others may be simple right cylinders. Depending on the final fuel form, mechanical processing of fuel to final shape may be as simple as cutting or shearing a fuel slug to final length. However, more-complicated processes of machining, extrusion, drawing, or other forming methods might be needed. If the fuel is a traditional rod-type form, a simple shearing process is usually all that is required. In this case little to no additional waste is produced during this step, other than the end trimmings from the fuel slugs, which can typically be recycled into a subsequent casting batch. If machining is required, machine chips would be produced which may be recycled or disposed, depending on available recycle processes. Given the low availability and intrinsic high value in HALEU, recycling of such machining scrap material would be warranted. Additional fuel processing may include hot forming activities, such as extrusion, in which the fuel is heated to $600-900^{\circ} \mathrm{C}$ and forced through a die. This could be followed by another cleaning step to remove potential lubricants or surface oxides. Further mechanical processing and heat treatments, $\left(500-850^{\circ} \mathrm{C}\right.$ for less than 60 minutes) may also be needed to obtain the necessary physical and microstructural characteristics. Some additional waste would be generated from any forming activity (e.g. leading and following blocks for extrusion).

Encapsulation: After the fuel has been formed and inspected it is ready for encapsulation into a cladding tube, which forms a fuel rod or fuel element. The cladding tubes would be brought into the facility from an off-site vendor. Cladding tubes are generally either a stainless steel, such as 316SS or 421SS, a high-alloy steel, such as a $9 \mathrm{Cr}-1 \mathrm{Mo}$ steel, or an alloy of zirconium. In the case of a liquid-metal bonded fuel, the cladding tubes may be preloaded with the bond metal (e.g. sodium) by the supplier or this operation can be completed in the fuel fabrication facility.

Fuel slugs may be loaded either vertically or horizontally into cladding tubes that are closed on one end. After the cladding tube is properly loaded, the open end is closed with an end plug that is welded into place. At this 
point the fuel is encapsulated and can be removed from the glovebox if further processing is required. Further processing may include heat treating welds, heating the liquid metal bond material, slight deformations of the cladding tube, or wire wrapping of the fuel rods for proper spacing in the reactor. Heat treating welds, if necessary, is generally done at temperatures lower than $800^{\circ} \mathrm{C}$ for less than 30 minutes. If the metal bond material must be heated, the final temperature would depend on the properties of the metallic bond material, in the case of sodium, the sealed tube is heated to about $500^{\circ} \mathrm{C}$ for up to 1 hour. The seal-welded fuel rods are inspected to verify closure, final dimensions, and other attributes, and then released for later assembly into fuel subassemblies.

\subsubsection{Ceramic Fuels Process}

The fabrication of fuels from three representative ceramic compounds is briefly outlined here: uranium oxide, uranium nitride and uranium silicide (other compound/ceramic fuels could also be fabricated with limited changes to the production line).

HALEU Receiving and Cleaning: Because the HALEU feedstock is coming from the FCF used fuel treatment process, an initial cleaning step may be necessary. In most cases this could be a simple external decontamination of the as-received ingots to minimize contamination spread to the gloveboxes. In some cases, depending on the condition of the HALEU feedstock, a mechanical or chemical cleaning may be necessary to remove oxide or slag layers. During the cleaning process, waste products would be generated.

Powder Production: Powder production could occur by three processes:

1. Uranium oxide would be produced by the reaction of uranium metal directly with oxygen through a process known as roasting. This involves a controlled atmosphere furnace with an agitation system to separate the oxidized material as it reacts. The oxidized powder would be a mix of oxidation states and would undergo another furnace run in a reducing atmosphere to transform the material into $\mathrm{UO}_{2}$. The resultant material would undergo a granulation step to form it into powder that would be compatible with the rotary press that produces the pellets.

2. Uranium silicide is made by first alloying silicon with the FCF metallic HALEU feedstock. Preferential loss of silicon during initial melting is minimized by using an arc-melting furnace to produce the uranium silicon alloy. After more 'homogenization melts', the ingot is mechanically broken up and ball-milled to reduce the material particle size to the proper powder size. The milling media is periodically replaced and disposed as waste.

3. Uranium nitride is produced through a hydride-dehydride/nitride-denitride process (i.e., forming uranium hydride, then decomposing the hydride to form powder that is then nitrided to form uranium nitride).This process is done by heating the bulk uranium in a hydrogen atmosphere (the optimal temperature is $225^{\circ} \mathrm{C}$ ) until the uranium has reacted with hydrogen followed by introduction of vacuum (still at temperature) until the material has turned into a fine powder. The process is repeated with nitrogen (the denitriding step reduces the material from $U_{2} \mathrm{~N}_{3}$ to the required $U N$ ).

Pellet Production: Following powder manufacture, fuel pellets are formed using an industry standard pelletizing process. Each powder requires optimizing parameters, with variables such as binder, die lubrication and pressing parameters evaluated. The residual contaminants expected to be present in the HALEU feedstock requires that the powder and pelletizing operations be performed within containment gloveboxes. Depending on the 
characteristics and chemical reactivity of the powder, the pelletizing process might need to be contained in inert atmosphere gloveboxes (for example, uranium silicide powder is potentially pyrophoric and must be handled away from atmospheric air).

The prepared fuel powder is fed into a rotary die where the material is pressed at room temperature to form "green" pellets (i.e., pellets that have been pressed from powder but not yet sintered into non-friable pellets). Green pellets are later heated in a sintering furnace (at temperatures ranging from 1450 to $2000^{\circ} \mathrm{C}$ ). The atmosphere of the furnace needs to vary depending on the material: silicide fuel requires an inert atmosphere while oxide and nitride need a reducing atmosphere, such as dry argon with a small amount of hydrogen.

Following sintering, pellets are ground to final diameter using centerless grinders (the desired length and end chamfer are imparted during pelletizing). Following quality inspection, the pellets are ready to be encapsulated into fuel rods.

Encapsulation: Fuel pellets approved by inspection are laid out in channeled trays in single columns. After the proper number of pellets are arranged into columns, the pellet columns are pushed horizontally into a horizontal cladding tube that is sealed on one end. The cladding tubes would be brought into the facility from an off-site vendor. Cladding tubes are generally either a stainless steel, such as 316SS or 421SS, a high-alloy steel, such as a $9 \mathrm{Cr}-1 \mathrm{Mo}$ steel, or an alloy of zirconium. After the cladding tube is properly loaded, the open end is closed with an end plug that is welded into place. The seal-welded fuel rods are inspected to verify closure, final dimensions, and other attributes, and then released for later assembly into fuel subassemblies.

\subsection{Alternative 2 - No Action}

Under the No Action Alternative, DOE would continue to electrometallurgically treat the EBR-II spent nuclear fuel (about 25 metric tons) and miscellaneous small lots of sodium bonded spent nuclear fuel, as decided in the ROD for the Treatment and Management of Sodium Bonded Spent Nuclear Fuel (FR Vol. 65, No. 182, September 19, 2000 pp. 56565-56570) and addressed in DOE's Sodium-Bonded EIS, DOE/EIS-306 (DOE 2000). DOE would continue to treat the fuel at MFC, blend with depleted uranium, if needed, to reduce the enrichment levels, and cast into ingots to store until deciding on appropriate disposition made through a separate NEPA review. 


\section{AFFECTED ENVIRONMENT}

\subsection{Idaho National Laboratory, Idaho}

\subsubsection{General Description of INL Site and Surrounding Area}

The INL Site consists of several complexes, each taking up less than 2 square miles, located across an 890 square miles expanse of otherwise undeveloped, cool desert terrain. DOE controls the INL Site land, which is located in southeastern Idaho and includes portions of five Idaho counties: Butte, Bingham, Bonneville, Clark, and Jefferson. Population centers in the region include the cities ( $>10,000$ people) of Idaho Falls, Pocatello, Rexburg, and Blackfoot, located further than 30 miles to the east and south; several smaller cities/communities $(<10,000$ people), including Arco, Howe, Mud Lake, Fort Hall Indian Reservation, and Atomic City, located around the site less than 30 miles away. Craters of the Moon National Monument is less than 20 miles to the west of the western INL boundary; Yellowstone and Grand Teton National Parks and the city of Jackson, Wyoming are located more than 70 miles northeast of the closest INL boundaries. (see Figure 1)

Populations potentially affected by INL Site activities include INL Site employees, ranchers who graze livestock in areas on or near the INL Site, hunters on or near the INL Site, residential populations in neighboring communities, travelers along U.S. Highway 20/26, and visitors at the Experimental Breeder Reactor I National Historic Landmark. There are no permanent residents on the INL Site.

The five Idaho counties that are part of the INL Site are in an attainment area or are unclassified for National Ambient Air Quality Standards status under the Clean Air Act (CAA). The nearest new source review (NSR) nonattainment area is located about 50 miles south of INL in Power and Bannock counties. INL is classified under the NSR minor source permit regulations as a Class II area-an area with reasonable or moderately good air quality.

Surface waters on the INL Site include the Big Lost River and Birch Creek. Both streams carry water on an irregular basis, with the majority of the flow diverted for irrigation before entering INL. The

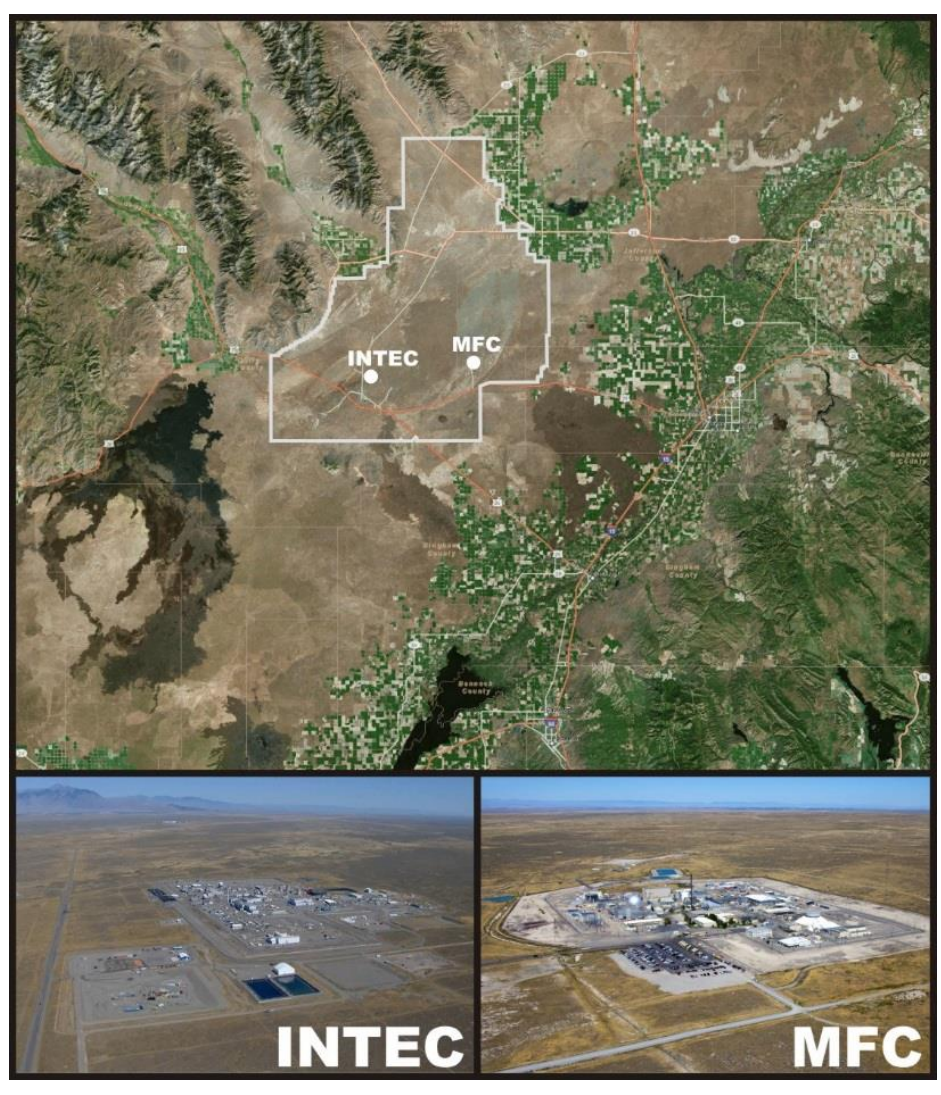

Figure 1. Figure shows the INL Site and the surrounding region with two insets showing locations of MFC and INTEC. Snake River Plain Aquifer, which lies between $220 \mathrm{ft}$ (at the north end of the Site) to $610 \mathrm{ft}$ (at the south end of the Site) below the surface of the Site. The geology above the Snake River Plain Aquifer-the vadose zone-is generally comprised of basalt (95\%), with a layer of soil or sediment on top of the basalt, and thin layers of 
sediments ( 1 to $20 \mathrm{ft}$ intervals) between basalt flows. The Snake River Plain Aquifer has similar geology as the overlying vadose zone and is generally 250 to $900 \mathrm{ft}$ thick.

Predominant natural vegetation of the INL Site consists of a shrub overstory with a perennial grass and forb understory. The most common shrub is Wyoming big sagebrush, although basin big sagebrush may dominate or co-dominate in areas with deep or sandy soils. Other common shrubs include green rabbitbrush, winterfat, spiny hopsage, gray horsebrush, gray rabbitbrush, and prickly phlox. The grass and forb understory consists of native grasses, thick-spiked wheatgrass, Indian ricegrass, bottlebrush squirreltail, needle-and-thread grass, Nevada bluegrass, and bluebunch wheatgrass and native forbs (i.e., tapertip hawksbeard, Hood's phlox, hoary false yarrow, paintbrush, globe-mallow, buckwheat, lupine, milkvetches, and mustards). Steep slopes and rises associated with buttes, bluffs and foothills may be dominated or co-dominated by Utah juniper. Part of the INL Site has been designated as the Sagebrush Steppe Ecosystem Reserve, which is managed to allow research opportunities and preserve sagebrush steppe habitat. The INL site is also designated as a National Environmental Research Park.

A total of 219 vertebrate species have been recorded as occurring at the INL Site. These wildlife species include amphibians, reptiles, rodents, carnivores, bats, big game and birds. Several of these species are sagebrush-obligate species, meaning that they rely upon sagebrush for survival. These species include sage sparrow, Brewer's sparrow, sage thrasher, northern sagebrush lizard, greater sage-grouse, and pygmy rabbit.

The INL Site also contains important breeding and nesting habitat for many species of raptors and songbirds. Most avian species occupying the INL Site use both sagebrush and grassland habitats from a few days for feeding and resting during migration to several months for breeding and raising young. Many bird species use specific habitats for foraging and reproduction. Species that primarily use sagebrush include greater sage-grouse, sage sparrow, Brewer's sparrow, sage thrasher, and loggerhead shrike. Species that occur mainly in grassland habitats include horned lark, western meadowlark, vesper sparrow, and grasshopper sparrow. Other common bird species at the INL Site include the following: rock wren, common nighthawk, red-tailed hawk, rough-legged hawk, prairie falcon, ferruginous hawk, golden eagle, and common raven. Although most raptors range widely across the INL Site for foraging, nesting habitat and structures are a limiting factor in population abundance and species diversity.

No resident species on the INL Site are listed as endangered or threatened under the Endangered Species Act. North American wolverine (Gulo gulo luscus) has not been documented at the INL Site, but may pass through it. Yellow-billed cuckoo (Coccyzus americanus) is known to breed in river valleys in southern Idaho (Federal Register, Vol. 79 No. 192, October 3, 2014), but has only been observed once near the INL Site at Atomic City. The INL Site has no designated critical habitat. Several species identified as Birds of Conservation Concern under the Migratory Bird Treaty Act or as Species of Greatest Conservation Need under state of Idaho regulations do occur on the INL Site, including bald eagle, Brewer's sparrow, burrowing owl, common nighthawk, golden eagle, grasshopper sparrow, greater sage-grouse, long-billed curlew, ferruginous hawk, Franklin's gull, loggerhead shrike, peregrine falcon, sage thrasher, sagebrush sparrow, short-eared owl, pygmy rabbit, hoary bat, little brown myotis, Townsend's big-eared bat, silver-haired bat, and western small-footed myotis. In 2010, a status review of little brown myotis was prepared and determined that emergency listing under the Endangered Species Act was warranted. The U.S. Fish and Wildlife Service has not made a final determination on listing of little brown myotis. 
Several wildlife species that were delisted but continue to be monitored are present on the INL Site. Bald eagle (Haliaeetus leucocephalus) was delisted in 2007, but is still protected under the Bald and Golden Eagle Protection Act. The Bald Eagle often winters in the Little Lost River Valley just north of the INL Site and some eagles' winter on the INL Site. American peregrine falcon (Falco peregrinus), delisted in 2009, has been observed infrequently on the northern part of the INL Site.

The cultural landscape of the INL represents nearly 13,500 years of human occupation and land use. Historic properties (those properties either listed or eligible for listing on the National Register of Historic Places [NRHP]) present within INL boundaries include both archaeological sites, and resources associated with the built environment. Archaeological sites encompass Native American habitation, and late 19th and early 20th century Euro-American sites associated with mining, canal and railroad construction, emigration and homesteading, agriculture, and ranching. Resources within the built environment consist of modern roads, railroad tracks, irrigation canals, and transmission and telephone lines, along with buildings and landscape features associated with the Arco Naval Proving Ground (NPG) and nuclear energy research at INL between 1949 and 1970, including the MFC and the INTEC. Additionally, the INL site contains numerous areas and natural resources of traditional cultural importance to the Shoshone-Bannock Tribes.

Two NRHP listed historic properties occur on the INL:

- Aviator's Cave is listed under Criterion D for archaeological potential, and cultural significance to the Shoshone-Bannock Tribes; and

- Experimental Breeder Reactor one (EBR-I) is listed under Criterion A for its association with events that have made a significant contribution to the broad patterns of American history, and Criterion C for distinctive characteristics of a method of construction.

\subsubsection{MFC Area (Area Potentially Affected by Alternative 1a and 1b)}

MFC, which is located about 38 miles west of Idaho Falls in Bingham County in the southeastern corner of INL. MFC is about 100 acres (inside the MFC fence) and about $2.7 \mathrm{mi}(4.3 \mathrm{~km})$ from the southern INL Site boundary. MFC is engaged in advanced nuclear power research and development, spent fuel and waste treatment technologies, national security programs, and projects to support space exploration. Formerly the Argonne National Laboratory-West (ANL-W), the MFC was established in 1949. For the next half-century, its primary mission was to take nuclear reactor power stations through the steps from design to demonstration.

\subsubsection{INTEC Area (Area Potentially Affected By Alternative 1b)}

INTEC is located in the southcentral portion of the INL Site in Butte County, between INL's Advanced Test Reactor (ATR) Complex and Critical Infrastructure Test Range Complex areas, and just south of the Big Lost River. INTEC is about 210 acres (inside the INTEC fence) and about $13.7 \mathrm{~km}$ ( $8.5 \mathrm{mi}$ ) from the southern INL Site boundary.

INTEC was a one-of-a-kind facility built in the early 1950s for reprocessing government-owned nuclear fuels from research and defense (primarily naval) reactors. Through April 1992, INTEC recovered uranium from the spent nuclear fuels for reuse. The current missions at INTEC include safe and secure storage and handling of spent nuclear fuel, special nuclear material, and waste by-products; waste treatment; and dismantle and demolition of facilities that are no longer needed. 


\section{ENVIRONMENTAL CONSEQUENCES}

The following sections evaluate direct, indirect, and cumulative environmental impacts that are likely to occur from the alternatives described in Section 2. Section 4.1 discusses the environmental impacts associated with Alternative 1. Section 4.2 discusses the environmental impacts associated with 'no action.' Each section discusses cause and effect relationships, including cumulative impacts, of the proposed actions on INL's natural, biological, and cultural resources; mitigative measures needed to lessen impacts; and those permits and regulations required to protect the resources.

During the EA scoping meeting, resource personnel identified that the proposed action could potentially affect air, biological and cultural resources and waste generation and management. This document evaluates impacts from construction/modification impacts to air, cultural and waste management (Section 4.1.1); normal operations to air, waste generation and management, and biological resources (Section 4.1.2); Accidents (Section 4.1.3); Transportation (Section 4.1.4); Destructive Acts (Section 4.1.5), and Cumulative Impacts (Section 4.1.6).

DOE uses engineered and administrative controls to make work safe and to reduce the potential for environmental consequences of its operations.

\subsection{Alternative 1 - Proposed Action: Use of DOE-Owned High-Assay Low- Enriched Uranium Stored at Idaho National Laboratory}

\subsubsection{Construction/Modification}

The proposed action would result in facility modifications that involve construction activities that include modifying facilities to support fuel-fabricating processes to separate the proposed processes (e.g., physical changes to buildings, ventilation separation, and so forth). These activities could affect air and cultural resources and waste generation and management.

\section{Air -}

The proposed action would likely result in fugitive dust and emissions. Before commencing any construction or modification, facility environmental personnel would complete an air permitting applicability determination (APAD). If an approval to construct (ATC) from Environmental Protection Agency (EPA) or a permit to construct (PTC) from the Idaho Department of Environmental Quality (DEQ) is required, an ATC or PTC would be obtained before commencing construction or modification. Construction and modification activities are not expected to release radiological contamination. However, activities could disturb materials containing asbestos; therefore, properly trained personnel would perform work on asbestos containing building materials.

\section{Cultural -}

The proposed action would not disturb areas outside facility areas, but could impact historic properties at MFC or INTEC. DOE has chosen to defer Section 106, per 36 CFR 800.14(b)(1)(ii), until after a NEPA decision has been made since the specific buildings to be used for the project have not been determined. As such, the final Area of Potential Effect (APE), impacts, and final agreement regarding mitigation of historic properties have not been identified. 
DOE has not determined which buildings at either MFC or INTEC would be used under the proposed action, but potential impacts include:

- installation of a 15-meter-tall emissions stacks

- installation of an exterior staircase

- interior modifications to accommodate production equipment, such as reconfiguration or installation of walls and ductwork

- replacement or installation of HVAC systems and filter housings

- updating of life safety systems and radiation monitors

- interior or exterior painting

No building demolition or major additions are anticipated for the proposed alternative.

Potential buildings may include Category 2 or 3 historic properties. Property categories are defined in the INL Cultural Resource Management Plan (CRMP; February 2016, Rev. 06) as Signature, Category 1, Category 2 or Category 3 Properties, from most significant to least. Category 2 Properties are defined as "Contributing INL properties directly associated with signature or key individual properties (control buildings, hot shops, and artifacts such as the TAN shielded locomotive)." Category 3 Properties are defined as "Contributing INL properties not directly associated with signature or key individual properties (e.g. cafeterias and warehouses)."

The anticipated Section 106 process for the HALEU project must consider potential effects to these property types. Typical mitigations of Category 2 and Category 3 historic properties include:

- Category 2 Historic Properties: Requires exterior and interior (when possible) documentation with large format photography meeting NPS HABS/HAER standards. The photographs will be preserved in the INL Cultural Resource Management Office (CRMO) along with architectural and engineering drawings that depict elevations, sections, details, and historic features; and with available historic photographs of construction, manufacture, and other activities or experiments, when possible. This documentation will be made available to scholars, researchers, and other interested parties (as appropriate in keeping with security standards). Additionally, these photographs and other documents will be available for future HABS/HAER studies.

- Category 3 Historic Properties: Requires photographic documentation meeting Idaho SHPO mitigation photo standards and completion of an Idaho Historic Sites Inventory form. This documentation will be preserved by the INL CRMO and made available to scholars, researchers, and other interested parties. Photography may be included in future HABS/HAER studies as appropriate to illustrate narrative.

DOE negotiated a process for deferment of Section 106 under the proposed action for Alternative 1, with the Idaho State Historic Preservation Office (SHPO). The following process was proposed by DOE and concurred on by the Idaho SHPO in an October 18, 2018 letter:

1) The Idaho SHPO will be allowed the opportunity to review the language in the EA regarding deferment of Section 106 once the document has been made available for public comment, as per 36 CFR 800.8(c)(2)(i);

2) DOE will prepare a Memorandum of Agreement (MOA) outlining how the Section 106 process will be completed, once determinations are made regarding the specific buildings involved in the undertaking. 
3) The MOA will be signed prior to making the NEPA decision. The NEPA decision will include stipulations for completing the Section 106 process.

If the undertaking involves a historic property, potential impacts to that property will be assessed, as outlined in the stipulations in the MOA:

- The Section 106 process will begin once the Project scope and description has been completed.

- Completion of the Section 106 process will include:

- Identification of historic properties within the APE;

- Evaluation of potential effects - immediate and cumulative direct and indirect - to historic properties from project activities.

4) Adverse Effects will be mitigated as identified in the INL Cultural Resource Management Plan, which may require consultation and concurrence between DOE-ID, the Shoshone-Bannock Tribes and the Idaho SHPO.

\section{Waste Management -}

Modifying buildings at MFC and INTEC for the new fuel fabrication processes would generate waste. The modifications for fuel fabrication would generate non-radioactive electronic waste, scrap metal, and other construction-related debris. Construction debris, electronic waste, and scrap metal would be recycled to the extent possible. Activities could require disposal of construction debris, concrete, coolants, and hydraulic/lubricating fluids. These wastes could be recycled or disposed at on-site facilities or sent off-site. These modifications could also generate radioactive waste. Constructing and modifying activities would likely generate mixed low-level waste (MLLW) (waste that is both radioactive and hazardous).

Based upon estimates supplied by MFC Engineering the amount of waste generated to refurbish a radiological facility would be about $218 \mathrm{~m}^{3}$. During FY 2018, INL sent 934- $\mathrm{m}^{3}$ low-level waste (LLW) to off-site facilities for disposal. INL would accumulate and store any waste generated per Federal and state regulations, and if required, treat and disposed at an off-site permitted/licensed facility.

\subsubsection{Normal Operations Activities}

Normal activities involved in the processing of HALEU include those described in Section 2.1.3 (e.g., cleaning, casting/alloying, cutting/shearing, machining/extruding/drawing, welding, dissolving, calcining/drying, pelleting, sintering, and grinding). Processes would use engineered and administrative controls to enhance safety and minimize the potential for environmental consequences. The only anticipated releases would be to the atmosphere.

Helpful Information for the Reader

When reviewing the impact of toxic and radiological releases to the air from normal operation, transportation, and accidents it may be useful to refer back to the section on 'Helpful Information' (page vi) for discussion on Scientific Notation, English/Metric Units, Understanding Small and Large Numbers, and Understanding Dose and Latent Cancer Fatalities.

\subsubsection{Releases to the Air}

Toxic Emissions-Nonradiological emissions would be minimal during operational stages. Welding emissions during cladding operations, as well as hazardous and toxic air emissions from processing, would from experience be expected to be below State of Idaho's toxic regulations. Ceramic fuels processing may involve using hydrochloric acid, hydrogen peroxide, and nitric acid. An acid scrubber system would be required to keep 
emissions below State of Idaho toxic limits. During encapsulation phase, some minor welding is performed to seal cladding tubes. These welding emissions are minor (an estimated 5.5 grams of chromium and 4.2 grams of nickel fume may be generated per batch based on the amount of welding rod used). Cleaning for external contamination may use small amounts of nitric acid (about 2 liters per batch). The APAD will quantify these emissions.

Radiological Impacts of Atmospheric Releases-During normal operations, radioactive particulate matter and gaseous emissions are possible. Based on the proposed processing operations, the potential for release of particulate contamination, and gaseous/vapor-phase radionuclides is greatest when the fuel is heated during the casting phase. During processing operations, the amount of radioactive material released during heating operations is assumed the same for each alternative. Operations planned for Alternatives $1 \mathrm{a}$ and $1 \mathrm{~b}$ involve heating with equivalent cleanup efficiencies, i.e., two stages of HEPA filtration each with at least $99.97 \%$ removal of airborne material with a particulate size of $0.3 \mu \mathrm{m}$ or greater. For the APAD evaluation HEPA filtration is not credited for gaseous/vapor phase radionuclides.

Each of the two facilities could process a maximum 2,500 kg of HALEU feedstock annually. The average radionuclide composition in the HALEU feedstock (TEV-3537) was used to determine the activity inventory in 2,500 $\mathrm{kg}$ as shown in Table 1.

Potential emissions were conservatively estimated using the maximum amount of feedstock material to be processed annually and appropriate emission factors based on the physical state of the material. Because the material could undergo heating, an alternative to the method in 40 CFR 61 Appendix D, approved for use at INL by EPA Region 10 (see letter from Donald Dossett [EPA Region 10] to Tim Safford (U.S. Department of Energy Idaho Operations Office [DOE-ID] Oct 19, 2017 [CCN 241475]) was used to determine the emission factors for radioactive solid materials with high melting and boiling points. These emission factors are:

- 1 for radioactive solid materials heated to temperatures greater than or equal to $90 \%$ of the boiling or subliming point;

- $\quad 1 \mathrm{E}-03$ for radioactive solid materials heated to temperatures greater than or equal to their melting point but less than $90 \%$ of their boiling or subliming point; and

- $1 \mathrm{E}-06$ for radioactive solid materials heated to temperatures above ambient temperature but less than their melting point.

Table 1 shows the emission factors and potential radionuclide emissions for 2,500 kg of HALEU feedstock material assuming the material is heated to a temperature of $2000 \mathrm{C}$, which equals or exceeds the maximum predicted temperature of both the metallic and ceramic processes. In this case, the emission potential is the product of the inventory and the emission factor and represents the amount that could potentially be released from the facility annually. It was assumed that the most likely manner for emissions to exit the processing facilities during normal operations would be from a stack similar to the stacks at the Fuel Manufacturing Facility or Irradiated Materials Characterization Laboratory at MFC. These stacks are about $15 \mathrm{~m}$ high with an exit diameter of $0.6 \mathrm{~m}$. 
Table 1. Radionuclide inventory in 2,500 kg HALEU feedstock material and unabated estimated annual potential to emit per processing facility.

\begin{tabular}{|c|c|c|c|}
\hline Radionuclide $^{a}$ & $\begin{array}{l}\text { Inventory in } 2,500 \mathrm{~kg}^{\mathrm{b}} \\
\text { (Ci) }\end{array}$ & $\begin{array}{c}\text { Emission Factor } \\
\text { (at } 2000 \mathrm{C} \text { ) }\end{array}$ & $\begin{array}{l}\text { Emission Potential } \\
\text { per Facility }{ }^{\mathrm{b}}(\mathrm{Ci} / \mathrm{yr})\end{array}$ \\
\hline$M n-54$ & $5.89 \mathrm{E}-02$ & 1 & $5.89 \mathrm{E}-02$ \\
\hline Co-60 & $7.86 \mathrm{E}-02$ & 0.001 & $7.86 \mathrm{E}-05$ \\
\hline Sr-90 & $5.40 \mathrm{E}+00$ & 1 & $5.40 \mathrm{E}+00$ \\
\hline Tc-99 & $6.41 \mathrm{E}-03$ & 0.000001 & $6.41 \mathrm{E}-09$ \\
\hline Sb-125 & 2.67E-01 & 1 & 2.67E-01 \\
\hline Cs-134 & 8.06E-02 & 1 & $8.06 \mathrm{E}-02$ \\
\hline Cs-135 & $7.68 \mathrm{E}-03$ & 1 & $7.68 \mathrm{E}-03$ \\
\hline Cs-137 & $1.74 \mathrm{E}+00$ & 1 & $1.74 \mathrm{E}+00$ \\
\hline Ce-144 & 5.34E-01 & 0.001 & $5.34 \mathrm{E}-04$ \\
\hline Eu-154 & $1.49 \mathrm{E}-01$ & 1 & 1.49E-01 \\
\hline Eu-155 & 2.67E-01 & 1 & $2.67 \mathrm{E}-01$ \\
\hline $\mathrm{Np}-237$ & $3.02 \mathrm{E}-02$ & 0.001 & $3.02 \mathrm{E}-05$ \\
\hline Pu-239 & $1.30 \mathrm{E}+01$ & 0.001 & $1.30 \mathrm{E}-02$ \\
\hline Pu-240 & $1.27 \mathrm{E}+00$ & 0.001 & $1.27 \mathrm{E}-03$ \\
\hline Am-241 & $5.25 \mathrm{E}-01$ & 1 & $5.25 \mathrm{E}-01$ \\
\hline U-234 & $2.48 \mathrm{E}+01$ & 0.001 & $2.48 \mathrm{E}-02$ \\
\hline U-235 & $1.04 \mathrm{E}+00$ & 0.001 & $1.04 \mathrm{E}-03$ \\
\hline U-236 & $8.38 \mathrm{E}-01$ & 0.001 & $8.38 \mathrm{E}-04$ \\
\hline U-238 & $6.68 \mathrm{E}-01$ & 0.001 & $6.68 \mathrm{E}-04$ \\
\hline U-232 & $2.77 \mathrm{E}-01$ & 0.001 & 2.77E-04 \\
\hline U-233 & 7.67E-03 & 0.001 & 7.67E-06 \\
\hline U-237 & 7.67E-03 & 0.001 & 4.49E-05 \\
\hline
\end{tabular}

a. Includes nuclides whose concentrations were measured by analysis or determined by modeling; other nuclides, including radioactive decay products, may be present at very low concentrations but does not change the conclusions of the analyses presented in the EA.

b. Alternative 1a assumes two processing facilities at MFC that would each process $2,500 \mathrm{~kg}$ annually for a total of 5,000 kg processed annually at MFC. Alternative $1 \mathrm{~b}$ assumes one processing facility at MFC and one processing facility at INTEC that would each process $2,500 \mathrm{~kg}$ annually. Thus the emission rates are per facility.

\section{Public Receptor}

The CAP88-PC computer code was used to model atmospheric transport of the emissions and calculate the potential effective dose (ED) at the following public receptor locations for Alternatives $1 \mathrm{a}$ and $1 \mathrm{~b}$ (see Figure 2) (ECAR-4321).

1. INL Site boundary nearest MFC: Located $5 \mathrm{~km}$ from MFC and $400 \mathrm{~m}$ north of the INL East entrance on Highway 20, which is accessible to the public, but there are no permanent residents (hypothetical receptor). Regulatory dose limits do not apply to this location. Doses are presented only for reference.

2. INL Site boundary nearest INTEC: Located about $14 \mathrm{~km}$ directly south of the INTEC entrance and $10 \mathrm{~km}$ west of Atomic City. The distance to INL's Site boundary northwest of INTEC is about the same distance, but the dose at the south receptor is higher. This location is accessible to the public, but there are no permanent residents. Regulatory dose limits do not apply to this location. Doses are presented only for reference.

3. Permanent resident nearest MFC: This is a farmhouse located $9 \mathrm{~km}$ from MFC and $3.1 \mathrm{~km}$ south of Highway 20, 3 km from INL's East entrance. Regulatory dose limits apply at this location. 
4. Atomic City: This town of population 29 (2010 census) is located about $2 \mathrm{~km}$ east of INL's South entrance on Highway 26. The residence nearest INTEC is located in Atomic City. Atomic City is about 21 $\mathrm{km} \mathrm{SSW}$ of MFC and $17 \mathrm{~km} \mathrm{SE} \mathrm{of} \mathrm{INTEC.} \mathrm{Regulatory} \mathrm{dose} \mathrm{limits} \mathrm{apply} \mathrm{at} \mathrm{this} \mathrm{location.}$

5. Frenchman's Cabin: This location is about $2 \mathrm{~km}$ south of the southern INL boundary near Big Southern Butte. This location is used to show INL Site compliance with 40 CFR 61, Subpart H - National Emissions Standards for Hazardous Air Pollutants (NESHAPs) Other Than Radon From Department of Energy Facilities, and is the location of the maximally exposed individual (MEI). The site may be inhabited during portions of the year. Regulatory dose limits do apply to this location because of the potential for occupation during a portion of the year.

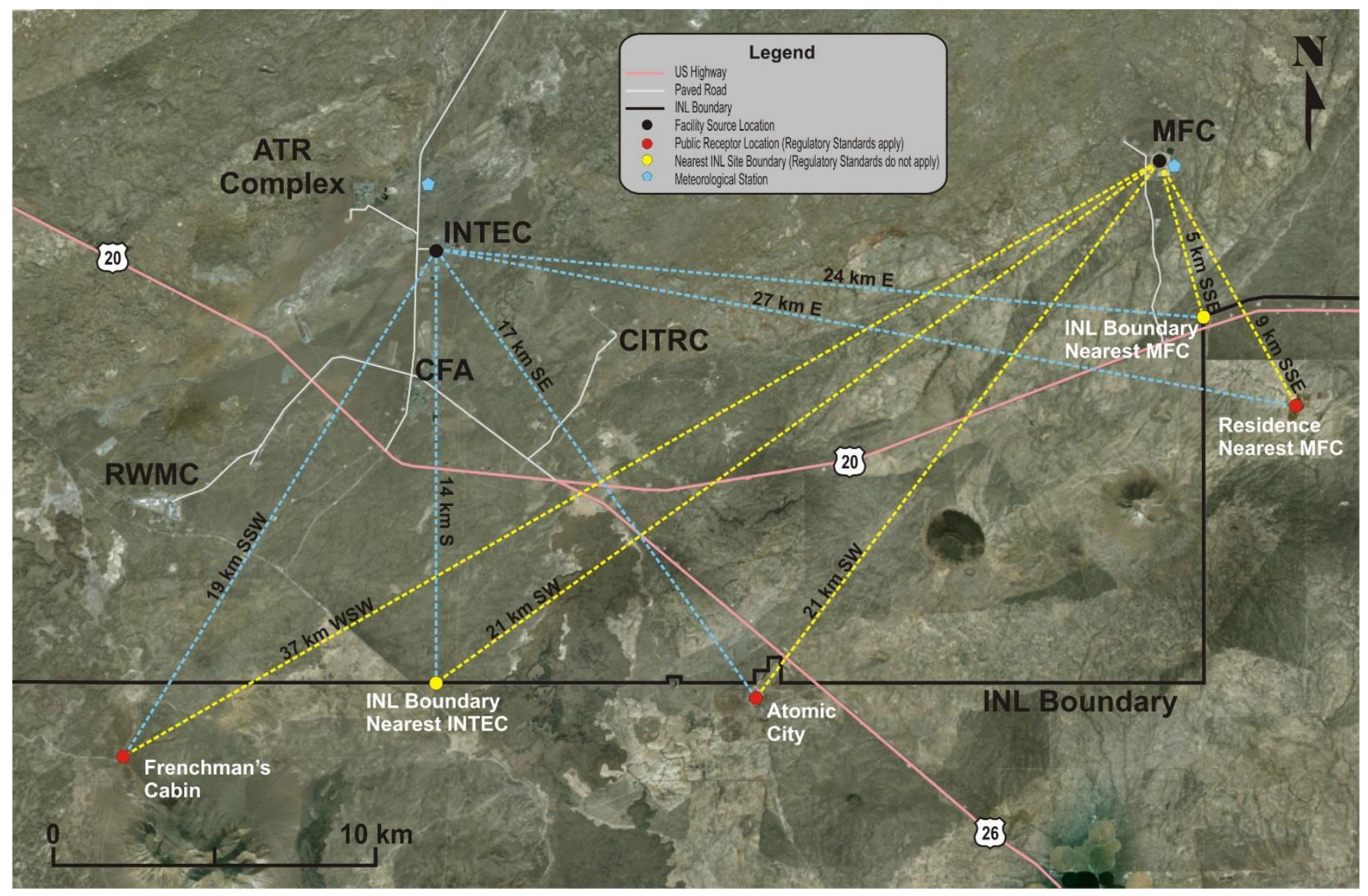

Figure 2. Actual and hypothetical public receptor locations for the air pathway analysis showing distance and direction from MFC and INTEC. Regulatory dose limits do not apply to the nearest boundary locations.

Table 2 shows the calculated potential EDs for public receptor locations from normal operations (ECAR-4321). For each alternative, the doses are well below the $10 \mathrm{mrem} /$ year federal standard set by 40 CFR 61, Subpart H for public exposures. Cumulative doses from all INL sources would also be well below the $10 \mathrm{mrem} /$ year dose standard at the INL MEl location (see Section 4.1.7). 
Table 2. Public air pathway potential dose estimates from normal operations (unmitigated dose).

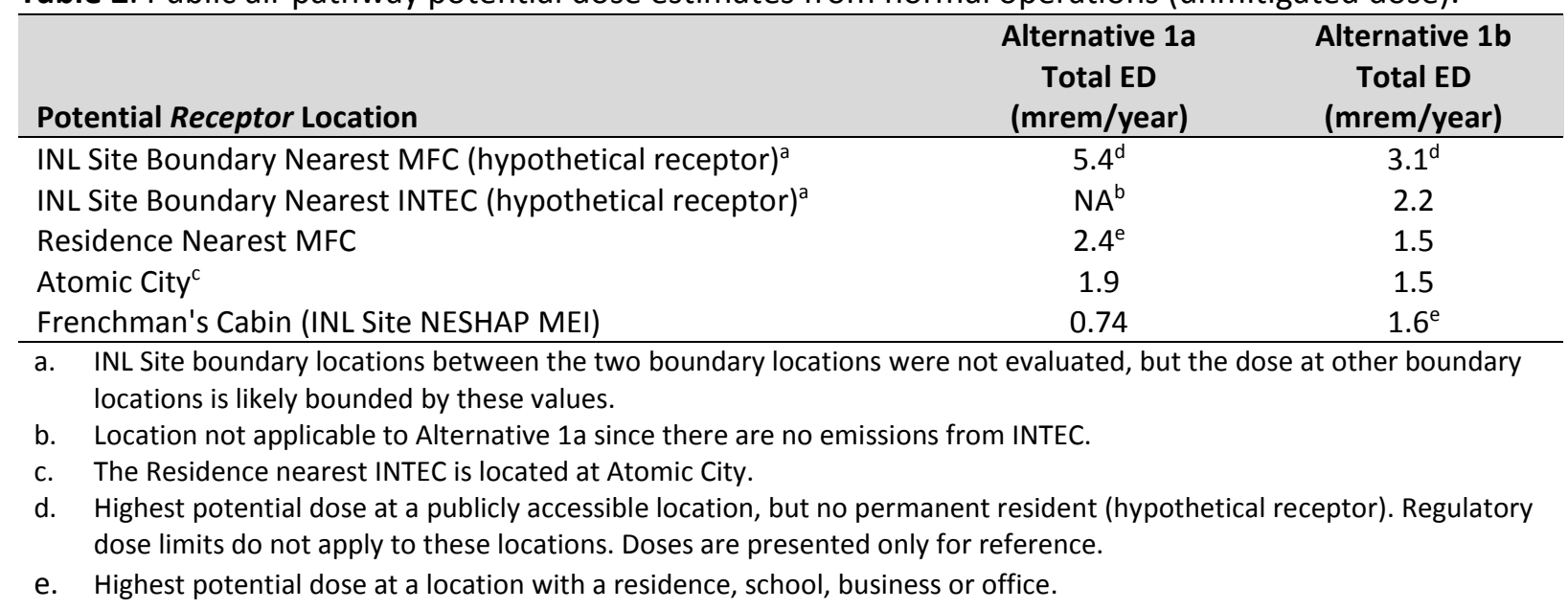

\section{Collocated Worker Receptor}

Collocated worker potential doses were calculated at $100 \mathrm{~m}$ from the source stack in the direction of maximum dose using the same atmospheric transport and dose model used for public dose calculations. However, worker dose estimates do not include the ingestion pathway because workers do not consume contaminated food products, and the inhalation and external doses were scaled to account for the reduced time workers would be onsite.

Table 3 shows the calculated EDs for collocated workers from normal operations (ECAR-4321). For Alternative $1 \mathrm{~b}$, doses are presented for both MFC and INTEC with the difference attributed to the different meteorological conditions. For each alternative, the doses are well below the 5,000 mrem/yr federal occupational dose limit for general employees (10 CFR 835.202).

Table 3. Collocated worker potential doses from operational radionuclide emissions (unmitigated dose).

\begin{tabular}{lccc}
\hline Alternative & Facility & $\begin{array}{c}\text { Feedstock Material } \\
\text { Processed Annually }\end{array}$ & $\begin{array}{c}\text { Total ED } \\
\text { (mrem/yr) }\end{array}$ \\
\hline 1a & MFC & $5,000 \mathrm{~kg}$ & 48 \\
\hline \multirow{2}{*}{ 1b } & MFC & $2,500 \mathrm{~kg}$ & 24 \\
& INTEC & $2,500 \mathrm{~kg}$ & 33 \\
\hline
\end{tabular}

a. Dose at $100 \mathrm{~m}$ from stack in direction of maximum dose.

\section{Groundwater Exposure Pathway}

Consequences of potential groundwater contamination resulting from air emissions depositing on soil and migrating to the aquifer were evaluated with the computer model GWSCREEN (Version 2.5a). GWSCREEN parameter input values and assumptions were generally consistent with those used to perform Track 2 CERCLA assessments for low probability hazard sites at INL (DOE-ID 1994). Thus, the groundwater pathway modeling is effectively a screening-level assessment and the impacts should be viewed as bounding.

In the model, radionuclides deposited on surficial soils are transported downward through the unsaturated zone and into the aquifer by natural precipitation and infiltration. In the unsaturated zone, radionuclides can undergo advection, longitudinal dispersion, sorption and radioactive chain decay and ingrowth. Once in the aquifer, similar transport and decay processes occur as contaminants move with the regional groundwater flow. The 
GWSCREEN model provides radionuclide concentrations in the aquifer and effective dose from groundwater ingestion.

All radionuclides were modeled except those with half-lives less than 1 year ( $\mathrm{Mn}-54, \mathrm{Ce}-144$ and U-237) because they would decay to insignificant levels before reaching the aquifer. Significant long-lived progeny are included explicitly in the model and assumed to be generated as the parent radionuclides decay. Short-lived radionuclide progeny were not modeled explicitly but are assumed to be in secular equilibrium with the parent. Where progeny are not explicitly modeled, the effective dose coefficients include the contribution from progeny.

Impacts to the aquifer are bounded by Alternative 1 a where all 10,000 kg of HALEU feedstock would be processed at MFC. The calculations assume all emissions for the 2-year operating period are deposited uniformly over a $400 \mathrm{~m} \times 400 \mathrm{~m}$ area surrounding the facility. This area is based on air-dispersion modeling results that indicate maximum deposition occurs approximately $100 \mathrm{~m}$ to $200 \mathrm{~m}$ from the emission stack. Assuming all radionuclides deposit within $200 \mathrm{~m}$ of the stack is a conservative assumption as the emissions would be spread over a much larger area. The groundwater receptor well is assumed located at the downgradient edge of the $400 \mathrm{~m} \times 400 \mathrm{~m}$ source zone, the location of maximum concentration.

The peak total effective dose (TED) from groundwater ingestions for Alternative $1 \mathrm{a}$ is $0.059 \mathrm{mrem} / \mathrm{yr}$ and occurs approximately 1,600 years after operations. The impact for Alternative $1 \mathrm{~b}$ would be approximately one half the effective dose of Alternative $1 \mathrm{a}(0.03 \mathrm{mrem} / \mathrm{yr})$ and would occur at both INTEC and MFC. There would be slight differences in the results based on differences between the two sites in terms of cumulative interbed thickness in the unsaturated zone and groundwater velocity in the aquifer, but the dose at each facility would not be greater than the $0.059 \mathrm{mrem} / \mathrm{yr}$ dose for Alternative 1a. Thus, the impact from either alternative would be less than $0.1 \%$ of the regulatory dose limit of $100 \mathrm{mrem} / \mathrm{yr}$ (DOE O 458.1).

\section{Surface Soil Exposure Pathway}

Estimated potential doses to public receptors (Table 2) and collocated workers (Table 3) from atmospheric emissions include impacts from air immersion, inhalation of contaminated air, ingestion of contaminated food products and direct radiation from ground deposition. Additional impacts from incidental ingestion of contaminated soil and inhalation of fugitive dust (particulate matter) were assessed by calculating soil concentrations due to build-up of particulate deposition, and comparing them to EPA preliminary remediation goals (PRGs) (ECAR-4321). PRGs are risk-based soil concentrations derived from standardized equations combining exposure information assumptions with EPA toxicity data. They are soil concentrations that would not likely result in adverse health impacts under reasonable maximum exposure conditions for longterm/chronic exposures.

Table 4 contains estimated soil concentrations calculated from maximum deposition rates calculated by the atmospheric transport model. For both MFC and INTEC, maximum deposition occurs $200 \mathrm{~m}$ from the stack in the NE direction. For both MFC and INTEC, this distance would likely be the shortest distance from a production facility to a location outside the facility fence. The soil concentrations from these deposition rates were also used to determine impacts to biota (see Section 4.1.2.3). There are no permanent human receptors at these locations and the soil concentrations are much greater than concentrations at actual public receptor locations farther from the facilities. Thus, impacts to public receptors are bounded by use of these concentrations. 
Table 4. Comparison of maximum radionuclide soil concentrations to EPA PRGs.

\begin{tabular}{|c|c|c|c|c|c|}
\hline Radionuclide & $\begin{array}{c}\text { Maximum Soil } \\
\text { Concentration } \\
\text { outside MFC } \\
(\mathrm{pCi} / \mathrm{g})^{\mathrm{a}}\end{array}$ & $\begin{array}{c}\text { Maximum Soil } \\
\text { Concentration } \\
\text { outside INTEC } \\
(\mathrm{pCi} / \mathrm{g})^{\mathrm{b}}\end{array}$ & $\begin{array}{c}\text { EPA Total PRG for } \\
\text { Soil Ingestion and } \\
\text { Inhalation }\end{array}$ & $\begin{array}{c}\text { Ratio of MFC } \\
\text { Maximum Soil } \\
\text { Concentration to } \\
\text { EPA PRG }\end{array}$ & $\begin{array}{c}\text { Ratio of INTEC } \\
\text { Maximum Soil } \\
\text { Concentration } \\
\text { to EPA PRG }\end{array}$ \\
\hline$M n-54$ & $2.16 \mathrm{E}-02$ & $1.49 \mathrm{E}-02$ & $3.8 \mathrm{E}+03$ & 5.69E-06 & $3.92 \mathrm{E}-06$ \\
\hline Co-60 & 5.06E-05 & 3.49E-05 & $8.3 E+01$ & 6.09E-07 & 4.20E-07 \\
\hline Sr-90 & $3.89 E+00$ & $2.68 \mathrm{E}+00$ & $8.9 E+00$ & 4.37E-01 & 3.01E-01 \\
\hline Tc-99 & 3.46E-09 & 2.39E-09 & $1.2 \mathrm{E}+02$ & 2.89E-11 & $1.99 E-11$ \\
\hline Sb-125 & $1.56 \mathrm{E}-01$ & 1.07E-01 & $5.4 \mathrm{E}+02$ & $2.88 \mathrm{E}-04$ & $1.98 \mathrm{E}-04$ \\
\hline Cs-134 & 4.35E-02 & 3.00E-02 & $1.4 \mathrm{E}+02$ & 3.11E-04 & $2.14 \mathrm{E}-04$ \\
\hline Cs-135 & 5.69E-03 & 3.92E-03 & $9.6 \mathrm{E}+01$ & 5.93E-05 & 4.09E-05 \\
\hline Cs-137 & $1.26 \mathrm{E}+00$ & $8.72 \mathrm{E}-01$ & $2.8 \mathrm{E}+01$ & $4.51 \mathrm{E}-02$ & 3.11E-02 \\
\hline Ce-144 & $1.85 \mathrm{E}-04$ & $1.27 \mathrm{E}-04$ & $2.2 \mathrm{E}+02$ & 8.41E-07 & 5.79E-07 \\
\hline Eu-154 & $1.02 \mathrm{E}-01$ & 7.03E-02 & $8.4 \mathrm{E}+01$ & $1.21 \mathrm{E}-03$ & 8.38E-04 \\
\hline Eu-155 & $1.72 \mathrm{E}-01$ & $1.18 \mathrm{E}-01$ & $6.7 \mathrm{E}+02$ & 2.57E-04 & $1.76 \mathrm{E}-04$ \\
\hline $\mathrm{Np}-237$ & 2.22E-05 & $1.53 \mathrm{E}-05$ & $6.2 \mathrm{E}+00$ & 3.60E-06 & $2.48 \mathrm{E}-06$ \\
\hline Pu-239 & $9.64 \mathrm{E}-03$ & $6.64 \mathrm{E}-03$ & $3.8 \mathrm{E}+00$ & $2.54 \mathrm{E}-03$ & $1.75 \mathrm{E}-03$ \\
\hline Pu-240 & $9.42 \mathrm{E}-04$ & 6.49E-04 & $3.8 \mathrm{E}+00$ & $2.48 \mathrm{E}-04$ & $1.71 \mathrm{E}-04$ \\
\hline Am-241 & $3.88 \mathrm{E}-01$ & 2.68E-01 & $4.8 \mathrm{E}+00$ & 8.09E-02 & $5.58 \mathrm{E}-02$ \\
\hline U-234 & $1.81 \mathrm{E}-02$ & $1.25 \mathrm{E}-02$ & $5.9 \mathrm{E}+00$ & $3.08 \mathrm{E}-03$ & $2.13 \mathrm{E}-03$ \\
\hline $\mathrm{U}-235$ & 7.61E-04 & $5.24 \mathrm{E}-04$ & $5.7 \mathrm{E}+00$ & $1.33 \mathrm{E}-04$ & 9.19E-05 \\
\hline U-236 & $6.13 E-04$ & 4.23E-04 & $6.3 \mathrm{E}+00$ & 9.77E-05 & $6.74 \mathrm{E}-05$ \\
\hline U-238 & $4.88 \mathrm{E}-04$ & 3.37E-04 & $4.4 \mathrm{E}+00$ & $1.10 \mathrm{E}-04$ & 7.59E-05 \\
\hline$U-232$ & 2.01E-04 & $1.38 \mathrm{E}-04$ & $1.9 \mathrm{E}+00$ & $1.08 \mathrm{E}-04$ & 7.41E-05 \\
\hline $\mathrm{U}-233$ & 5.62E-06 & 3.87E-06 & $5.8 \mathrm{E}+00$ & $9.70 \mathrm{E}-07$ & 6.69E-07 \\
\hline \multirow[t]{2}{*}{ U-237 } & 4.44E-07 & $3.06 \mathrm{E}-07$ & $6.5 \mathrm{E}+04$ & $6.83 \mathrm{E}-12$ & $4.71 \mathrm{E}-12$ \\
\hline & & & Sum of Ratios ${ }^{d}$ & 0.57 & 0.39 \\
\hline
\end{tabular}

a. Soil concentrations near MFC based on annual emission rate of 5,000 kg (2,500 kg per facility). Facilities are assumed collocated.

b. Soil concentrations near INTEC based on annual emission rate of $2,500 \mathrm{~kg}$.

c. PRGs are based on a target risk of 1E-06. PRG is the total PRG for the soil ingestion and inhalation of fugitive dust exposure pathways.

d. Sum of Ratios less than 1 indicates concentrations would not result in adverse human health impacts. The lifetime cancer risk is less than one in one million.

The results in Table 4 indicate maximum radionuclide soil concentrations are less than EPA PRGs. Sum of ratios values less than one is evidence that contaminated soils would not result in adverse human health impacts.

\subsubsection{Waste Generation and Management}

Routine maintenance and operations would generate a variety of waste streams, including both radioactive and non-radioactive wastes. Non-radioactive wastes would include trash and waste found at any industrial facility, including common trash, wastewater, hydraulic and lubricating fluids, scrap metal, and possibly small amounts of hazardous waste (e.g., electronic circuit boards, solvent contaminated wipes).

Common trash would be disposed at the on-site industrial waste landfill. Hazardous waste/mixed waste would be accumulated and stored per federal and state regulations, treated and disposed at an off-site permitted/licensed facility. Solid LLW may include scrap metal, HEPA filters, used personal protective equipment, wipes, rags, and decontamination fluids. Solid LLW would be sent to an off-INL disposal facility permitted/licensed to accept LLW. Liquid LLW would be solidified and sent to an off-site disposal facility permitted/licensed to accept LLW. The volume of various LLW generated during routine operations are expected 
to be less than $20 \mathrm{~m}^{3}$ per year (based on FY2018 generation rates at MFC); the additional LLW disposal from the proposed action is less than a $2.5 \%$ increase in the volume sent to off-site disposal facilities each year.

Cleaning for external contamination may use small amounts of nitric acid (about 2 liters per batch. During ceramic fuels processing using hydrochloric acid, hydrogen peroxide, and nitric acid would generate a MLLW. MLLW when generated, would be accumulated and stored per federal and state regulations, treated if required, and disposed at an off-site permitted/licensed facility. For purposes of this analysis, it is assumed that the majority of materials comes from the processing of EBR-II spent fuel. EBR-II missions involved defense-related activities. Therefore, the transuranic waste generated from production of HALEU fuel would be defense-related and can be disposed at the Waste Isolation Pilot Plant (WIPP) (McFarlane 2001). Based on past operations of the FCF and the HALEU feedstock, less than $1 \mathrm{~m}^{3}$ of transuranic waste may be generated. Based on the starting point (HALEU feedstock) in the production of HALEU fuel, the HALEU process by definition would not generate Greater-Than-Class $C$ waste nor would it generate High-Level Waste.

The environmental impacts associated with disposal and transportation of LLW are addressed in the Final Waste Management Programmatic Environmental Impact Statement for Managing Treatment, Storage, and Disposal of Radioactive and Hazardous Waste (DOE 1997a), the EA for the Replacement Capability for Disposal of RemoteHandled Low-Level Radioactive Waste Generated at the DOE's Idaho Site (DOE 2011b), and the Final Site-Wide Environmental Impact Statement for the Continued Operation of the DOE/National Nuclear Security Administration Nevada National Security Site and Off-Site Locations in the State of Nevada (DOE 2013a).

\section{Handling and Examinations in Other MFC Facilities -}

Fuel fabrication would result in waste generation at other facilities at MFC where the fuel can be analyzed. The materials and fuel specimens proposed for analysis would not be appreciably different from current testing.

Based on INL's FY2018 LLW generation rate of $934 \mathrm{~m}^{3}$, the increase in LLW generation would represent less than $2.5 \%$ of the volume generated at INL each year. MLLW may also be generated during these operations. If MLLW were generated, it would be accumulated and stored per Federal and state regulations, treated if required, and disposed at an off-site permitted/licensed facility. The proposed processes should generate less than $1 \mathrm{~m}^{3}$ of transuranic waste. The environmental impacts associated with disposal of transuranic waste are addressed in the Waste Isolation Pilot Plant Disposal Phase Final Supplemental Environmental Impact Statement (DOE 1997b).

\subsubsection{Biological Resources}

The RESRAD-BIOTA (Version 1.8) computer code (http://resrad.evs.anl.gov/codes/resrad-biota/) was used to model radiation exposures to terrestrial biota resulting from soil contaminated by airborne releases from the HALEU processing facilities at INTEC and/or MFC. The Level 1 analysis in RESRAD-BIOTA provides generic limiting concentrations of radionuclides in environmental media, termed Biota Concentration Guides (BCG). Each biota concentration guide is the environmental concentrations of a given radionuclide in soil or water. The contaminated soil subsequently results in contamination in air and in different food sources used by biota. Both external radiation and internal radiation are considered in the dose assessment.

For the HALEU analysis, soil concentrations resulting from emissions under Alternatives 1a (MFC - $5000 \mathrm{~kg}$ feed processed per year for two years) and $1 \mathrm{~b}$ (MFC and INTEC -2500 kg per each facility processed per year for two years) were evaluated. The maximum radionuclide concentrations in soil resulting from deposition under each scenario were evaluated for dose to terrestrial biota. 
The potential radionuclide concentrations in surface soils around the INTEC and MFC were estimated using radionuclide-specific deposition rates modeled by the CAP88-PC computer code, as discussed in Section 4.1.2.1. The locations at which the maximum deposition rates were estimated to occur were identified at $200 \mathrm{~m}$ northeast of MFC and $200 \mathrm{~m}$ northeast of INTEC. The concentrations of radionuclides in the soil at these locations were calculated using an algorithm which includes the deposition rate, radioactive decay and leaching of dissolved materials down through the soil via water infiltration (VFS-ID-ESER-NEPA-044, 2018). The calculated concentrations of radionuclides at the locations of maximum deposition are shown in Tables 5 and 6.

A Level 1 screening analysis was preformed using the maximum soil concentrations for each alternative scenario [MFC for Alternative 1a (Table 5) and INTEC for Alternative 1b (Table 6)]. Because RESRAD-BIOTA does not offer Mn-54, Pu-240, U-232, U-236, and U-237 as input choices, these radionuclides were handled as follows: 1) Mn54 was summed with Co-60; 2) Pu-240 was summed with Pu-239; 3) U-236 was summed with U-238; 4) U-232 was entered as Th-228 (a daughter in the decay series); and 5) U-237 was eliminated. The Level 1 screening analysis represents the most conservative estimate of impacts of contaminants in soil on terrestrial biota accessing the soil. The bases for these decisions are discussed in VFS-ID-ESER-NEPA-044.

The results of the analyses show that for each alternative terrestrial animals are the limiting species and the soil concentration/BCG ratios do not cumulatively exceed 1 . This shows that the limits established for protection of terrestrial biota would not be exceeded for either alternative. 
Table 5. Results of Level 1 RESRAD-BIOTA analysis of proposed HALEU releases at MFC (Alternative 1a). Terrestrial animals are the limiting organism.

\begin{tabular}{|c|c|c|c|c|c|}
\hline \multicolumn{6}{|c|}{$\begin{array}{l}\text { Terrestrial BCG Report for Level } 1 \\
\text { Title: HALEU - MFC }\end{array}$} \\
\hline \multicolumn{6}{|c|}{$\begin{array}{l}\text { (Summed) Total Ratio for Limiting Organism: } 2.38 \mathrm{E}-01 \\
\text { (Summed) Soil Ratio for Limiting Organism: } 2.38 \mathrm{E}-01\end{array}$} \\
\hline & \multicolumn{5}{|c|}{ Terrestrial Animal } \\
\hline & \multicolumn{4}{|l|}{ Soil } & TOTAL \\
\hline Nuclide $^{a}$ & $\begin{array}{l}\text { Concentration } \\
\text { (pCi/g) }\end{array}$ & $\begin{array}{c}\text { BCG } \\
(\mathrm{pCi} / \mathrm{g})\end{array}$ & Ratio & $\begin{array}{l}\text { Limiting } \\
\text { Organism }\end{array}$ & Ratio \\
\hline Am-241 & 0.388 & $3.89 \mathrm{E}+03$ & $9.96 \mathrm{E}-05$ & Yes & $9.96 \mathrm{E}-05$ \\
\hline $\mathrm{Ce}-144$ & 0.000185 & $1.44 \mathrm{E}+03$ & $1.28 \mathrm{E}-07$ & Yes & $1.28 \mathrm{E}-07$ \\
\hline Co-60 & 0.0217 & $6.92 \mathrm{E}+02$ & $3.14 \mathrm{E}-05$ & Yes & $3.14 \mathrm{E}-05$ \\
\hline Cs-134 & 0.0435 & $1.13 \mathrm{E}+01$ & $3.85 \mathrm{E}-03$ & Yes & $3.85 \mathrm{E}-03$ \\
\hline Cs-135 & 0.00569 & $2.62 \mathrm{E}+02$ & 2.17E-05 & Yes & 2.17E-05 \\
\hline Cs-137 & 1.26 & $2.08 \mathrm{E}+01$ & 6.07E-02 & Yes & 6.07E-02 \\
\hline Eu-154 & 0.102 & $1.29 \mathrm{E}+03$ & $7.90 \mathrm{E}-05$ & Yes & $7.90 \mathrm{E}-05$ \\
\hline Eu-155 & 0.172 & $1.58 \mathrm{E}+04$ & $1.09 \mathrm{E}-05$ & Yes & $1.09 \mathrm{E}-05$ \\
\hline Np-237 & 0.0000222 & $3.86 \mathrm{E}+03$ & $5.75 \mathrm{E}-09$ & Yes & 5.75E-09 \\
\hline Pu-239 & 0.0106 & $6.11 E+03$ & $1.73 \mathrm{E}-06$ & Yes & $1.73 \mathrm{E}-06$ \\
\hline Sb-125 & 0.156 & $3.52 \mathrm{E}+03$ & $4.43 \mathrm{E}-05$ & Yes & $4.43 \mathrm{E}-05$ \\
\hline Sr-90 & 3.89 & $2.25 \mathrm{E}+01$ & $1.73 \mathrm{E}-01$ & Yes & $1.73 \mathrm{E}-01$ \\
\hline Tc-99 & 0.00000000346 & $4.49 \mathrm{E}+03$ & $7.70 \mathrm{E}-13$ & Yes & $7.70 \mathrm{E}-13$ \\
\hline Th-228 & 0.000201 & $5.30 \mathrm{E}+02$ & $3.79 \mathrm{E}-07$ & Yes & 3.79E-07 \\
\hline U-233 & 0.00000562 & $4.83 \mathrm{E}+03$ & 1.16E-09 & Yes & 1.16E-09 \\
\hline U-234 & 0.0181 & $5.13 \mathrm{E}+03$ & $3.53 \mathrm{E}-06$ & Yes & $3.53 \mathrm{E}-06$ \\
\hline U-235 & 0.000761 & $2.77 \mathrm{E}+03$ & $2.75 \mathrm{E}-07$ & Yes & $2.75 \mathrm{E}-07$ \\
\hline U-238 & 0.0011 & $1.58 \mathrm{E}+03$ & $6.97 \mathrm{E}-07$ & Yes & $6.97 \mathrm{E}-07$ \\
\hline \multirow[t]{3}{*}{ Summed } & - & - & $2.38 \mathrm{E}-01$ & - & $2.38 \mathrm{E}-01$ \\
\hline & \multicolumn{5}{|c|}{ Terrestrial Plant } \\
\hline & \multicolumn{4}{|l|}{ Soil } & TOTAL \\
\hline Nuclide $^{a}$ & $\begin{array}{l}\text { Concentration } \\
(\mathrm{pCi} / \mathrm{g})\end{array}$ & $\begin{array}{c}\text { BCG } \\
\text { (pCi/g) }\end{array}$ & Ratio & $\begin{array}{l}\text { Limiting } \\
\text { Organism }\end{array}$ & Ratio \\
\hline Am-241 & 0.00131 & $1.57 \mathrm{E}+04$ & $8.33 \mathrm{E}-08$ & No & $8.33 \mathrm{E}-08$ \\
\hline Ce-144 & 0.000185 & $1.39 \mathrm{E}+04$ & $1.33 \mathrm{E}-08$ & No & $1.33 \mathrm{E}-08$ \\
\hline Co-60 & 0.0217 & $6.13 \mathrm{E}+03$ & $3.54 \mathrm{E}-06$ & No & $3.54 \mathrm{E}-06$ \\
\hline Cs-134 & 0.0435 & $1.09 \mathrm{E}+03$ & $4.00 \mathrm{E}-05$ & No & $4.00 \mathrm{E}-05$ \\
\hline Cs-135 & 0.00569 & $2.81 \mathrm{E}+04$ & $2.02 \mathrm{E}-07$ & No & $2.02 \mathrm{E}-07$ \\
\hline Cs-137 & 1.26 & $2.21 \mathrm{E}+03$ & $5.71 \mathrm{E}-04$ & No & $5.71 \mathrm{E}-04$ \\
\hline Eu-154 & 0.102 & $1.25 \mathrm{E}+04$ & $8.18 \mathrm{E}-06$ & No & $8.18 \mathrm{E}-06$ \\
\hline Eu-155 & 0.172 & $1.53 \mathrm{E}+05$ & $1.13 \mathrm{E}-06$ & No & $1.13 \mathrm{E}-06$ \\
\hline Np-237 & 0.0000222 & $8.15 E+03$ & $2.73 \mathrm{E}-09$ & No & $2.73 \mathrm{E}-09$ \\
\hline Pu-239 & 0.0106 & 1.27E+04 & $8.36 \mathrm{E}-07$ & No & $8.36 \mathrm{E}-07$ \\
\hline Sb-125 & 0.156 & $3.49 \mathrm{E}+04$ & 4.47E-06 & No & 4.47E-06 \\
\hline Sr-90 & 3.89 & $3.58 \mathrm{E}+03$ & 1.09E-03 & No & 1.09E-03 \\
\hline Tc-99 & 0.00000000346 & $2.19 E+04$ & $1.58 \mathrm{E}-13$ & No & $1.58 \mathrm{E}-13$ \\
\hline Th-228 & 0.000201 & $6.42 \mathrm{E}+03$ & $3.13 \mathrm{E}-08$ & No & $3.13 \mathrm{E}-08$ \\
\hline U-233 & 0.00000562 & $5.23 \mathrm{E}+04$ & 1.07E-10 & No & 1.07E-10 \\
\hline U-234 & 0.0181 & $5.16 \mathrm{E}+04$ & $3.51 \mathrm{E}-07$ & No & $3.51 \mathrm{E}-07$ \\
\hline U-235 & 0.000761 & $2.74 \mathrm{E}+04$ & $2.77 \mathrm{E}-08$ & No & $2.77 \mathrm{E}-08$ \\
\hline U-238 & 0.0011 & 1.57E+04 & $7.00 \mathrm{E}-08$ & No & $7.00 \mathrm{E}-08$ \\
\hline Summed & - & - & $1.74 \mathrm{E}-03$ & - & $1.74 \mathrm{E}-03$ \\
\hline
\end{tabular}


Table 6. Results of Level 1 RESRAD-BIOTA analysis of proposed HALEU releases at INTEC (Alternative $1 \mathrm{~b}$ ). Terrestrial animals are the limiting organism.

\begin{tabular}{|c|c|c|c|c|c|}
\hline \multicolumn{6}{|c|}{$\begin{array}{l}\text { Terrestrial BCG Report for Level } 1 \\
\text { Title: HALEU - INTEC }\end{array}$} \\
\hline \multirow{2}{*}{\multicolumn{6}{|c|}{$\begin{array}{l}\text { (Summed) Total Ratio for Limiting Organism: } 1.64 \mathrm{E}-01 \\
\text { (Summed) Soil Ratio for Limiting Organism: } 1.64 \mathrm{E}-01\end{array}$}} \\
\hline & & & & & \\
\hline & \multicolumn{5}{|c|}{ Terrestrial Animal } \\
\hline & \multicolumn{4}{|c|}{ Soil } & TOTAL \\
\hline Nuclide $^{a}$ & $\begin{array}{l}\text { Concentration } \\
(\mathrm{pCi} / \mathrm{g})\end{array}$ & BCG (pCi/g) & Ratio & $\begin{array}{l}\text { Limiting } \\
\text { Organism }\end{array}$ & Ratio \\
\hline Am-241 & 0.268 & $3.89 E+03$ & $6.88 \mathrm{E}-05$ & Yes & $6.88 \mathrm{E}-05$ \\
\hline Ce-144 & 0.000127 & $1.44 \mathrm{E}+03$ & $8.81 \mathrm{E}-08$ & Yes & $8.81 \mathrm{E}-08$ \\
\hline Co-60 & 0.0149 & $6.92 \mathrm{E}+02$ & $2.15 \mathrm{E}-05$ & Yes & $2.15 \mathrm{E}-05$ \\
\hline Cs-134 & 0.03 & $1.13 \mathrm{E}+01$ & $2.66 \mathrm{E}-03$ & Yes & $2.66 \mathrm{E}-03$ \\
\hline Cs-135 & 0.00292 & $2.62 \mathrm{E}+02$ & $1.12 \mathrm{E}-05$ & Yes & $1.12 \mathrm{E}-05$ \\
\hline Cs-137 & 0.872 & $2.08 \mathrm{E}+01$ & $4.20 \mathrm{E}-02$ & Yes & $4.20 \mathrm{E}-02$ \\
\hline Eu-154 & 0.0703 & $1.29 E+03$ & $5.45 \mathrm{E}-05$ & Yes & $5.45 \mathrm{E}-05$ \\
\hline Eu-155 & 0.0118 & $1.58 \mathrm{E}+04$ & $7.45 \mathrm{E}-07$ & Yes & $7.45 \mathrm{E}-07$ \\
\hline Np-237 & 0.0000153 & $3.86 \mathrm{E}+03$ & $3.96 \mathrm{E}-09$ & Yes & $3.96 \mathrm{E}-09$ \\
\hline Pu-239 & 0.00729 & $6.11 \mathrm{E}+03$ & 1.19E-06 & Yes & 1.19E-06 \\
\hline Sb-125 & 0.107 & $3.52 E+03$ & $3.04 \mathrm{E}-05$ & Yes & $3.04 \mathrm{E}-05$ \\
\hline Sr-90 & 2.68 & $2.25 \mathrm{E}+01$ & 1.19E-01 & Yes & 1.19E-01 \\
\hline Tc-99 & 0.00000000239 & $4.49 E+03$ & $5.32 \mathrm{E}-13$ & Yes & $5.32 \mathrm{E}-13$ \\
\hline Th-228 & 0.000138 & $5.30 \mathrm{E}+02$ & $2.60 \mathrm{E}-07$ & Yes & $2.60 \mathrm{E}-07$ \\
\hline U-233 & 0.00000387 & $4.83 E+03$ & $8.02 \mathrm{E}-10$ & Yes & $8.02 \mathrm{E}-10$ \\
\hline U-234 & 0.0125 & $5.13 \mathrm{E}+03$ & $2.44 \mathrm{E}-06$ & Yes & $2.44 \mathrm{E}-06$ \\
\hline U-235 & 0.000524 & $2.77 \mathrm{E}+03$ & $1.89 \mathrm{E}-07$ & Yes & $1.89 \mathrm{E}-07$ \\
\hline U-238 & 0.00076 & $1.58 \mathrm{E}+03$ & $4.82 \mathrm{E}-07$ & Yes & $4.82 \mathrm{E}-07$ \\
\hline \multirow[t]{3}{*}{ Summed } & - & - & $1.64 \mathrm{E}-01$ & - & $1.64 \mathrm{E}-01$ \\
\hline & \multicolumn{5}{|c|}{ Terrestrial Plant } \\
\hline & \multicolumn{4}{|c|}{ Soil } & TOTAL \\
\hline Nuclide & $\begin{array}{l}\text { Concentration } \\
(\mathrm{pCi} / \mathrm{g})\end{array}$ & BCG (pCi/g) & Ratio & $\begin{array}{l}\text { Limiting } \\
\text { Organism }\end{array}$ & Ratio \\
\hline Am-241 & 0.268 & $2.15 E+04$ & $1.24 \mathrm{E}-05$ & No & $1.24 \mathrm{E}-05$ \\
\hline Ce-144 & 0.000127 & $1.39 \mathrm{E}+04$ & $9.12 \mathrm{E}-09$ & No & $9.12 \mathrm{E}-09$ \\
\hline Co-60 & 0.0149 & $6.13 E+03$ & $2.43 \mathrm{E}-06$ & No & $2.43 \mathrm{E}-06$ \\
\hline Cs-134 & 0.03 & $1.09 \mathrm{E}+03$ & $2.76 \mathrm{E}-05$ & No & $2.76 \mathrm{E}-05$ \\
\hline Cs-135 & 0.00292 & $2.81 \mathrm{E}+04$ & $1.04 \mathrm{E}-07$ & No & $1.04 \mathrm{E}-07$ \\
\hline Cs-137 & 0.872 & $2.21 \mathrm{E}+03$ & $3.95 \mathrm{E}-04$ & No & $3.95 \mathrm{E}-04$ \\
\hline Eu-154 & 0.0703 & $1.25 \mathrm{E}+04$ & 5.64E-06 & No & $5.64 \mathrm{E}-06$ \\
\hline Eu-155 & 0.0118 & $1.53 \mathrm{E}+05$ & $7.72 \mathrm{E}-08$ & No & $7.72 \mathrm{E}-08$ \\
\hline Np-237 & 0.0000153 & $8.15 E+03$ & $1.88 \mathrm{E}-09$ & No & $1.88 \mathrm{E}-09$ \\
\hline Pu-239 & 0.00729 & $1.27 \mathrm{E}+04$ & $5.75 \mathrm{E}-07$ & No & $5.75 \mathrm{E}-07$ \\
\hline Sb-125 & 0.107 & $3.49 E+04$ & 3.07E-06 & No & 3.07E-06 \\
\hline Sr-90 & 2.68 & $3.58 \mathrm{E}+03$ & $7.49 \mathrm{E}-04$ & No & $7.49 \mathrm{E}-04$ \\
\hline Tc-99 & 0.00000000239 & $2.19 E+04$ & $1.09 \mathrm{E}-13$ & No & $1.09 \mathrm{E}-13$ \\
\hline Th-228 & 0.000138 & $6.42 \mathrm{E}+03$ & $2.15 \mathrm{E}-08$ & No & $2.15 \mathrm{E}-08$ \\
\hline U-233 & 0.00000387 & $5.23 E+04$ & $7.40 \mathrm{E}-11$ & No & $7.40 \mathrm{E}-11$ \\
\hline U-234 & 0.0125 & $5.16 \mathrm{E}+04$ & $2.42 \mathrm{E}-07$ & No & $2.42 \mathrm{E}-07$ \\
\hline U-235 & 0.000524 & $2.74 \mathrm{E}+04$ & $1.91 \mathrm{E}-08$ & No & $1.91 \mathrm{E}-08$ \\
\hline U-238 & 0.00076 & $1.57 \mathrm{E}+04$ & $4.83 \mathrm{E}-08$ & No & $4.83 \mathrm{E}-08$ \\
\hline Summed & - & - & $1.20 \mathrm{E}-03$ & - & $1.20 \mathrm{E}-03$ \\
\hline
\end{tabular}




\subsubsection{Accident Consequences}

Accident consequences for Alternative 1 (Proposed Action) were evaluated for events related to processing of HALEU. Accident types considered included thermal stress of fire on $50 \mathrm{~kg}$ uranium solids, spill or free-fall drop of molten metal, and accidents resulting in solid ingot free-fall drop or impact (ECAR-4310). The potential for nuclear criticality exists due to the quantity and form of material being processed. However, engineered and administrative controls would be incorporated into the facility and process operations to prevent and mitigate worker risk associated with this hazard.

DOE-Hdbk-3010-94 states that no significant airborne release is postulated from spill and impact of solid uranium, so those types of events are not addressed further. The handbook further states that release fractions for disturbed molten metal surface under dynamic conditions such as a spill or free-fall drop are higher than that for pieces or powder under thermal stress (fire). Therefore, the bounding and most severe postulated accident for the proposed action is a spill or free-fall drop of molten uranium during material processing. This accident could occur from an initiating event such as natural phenomena occurrence (i.e. severe seismic event), operator error, or from unspecified facility structural failures. The combined probability of initiating event and likelihood of equipment failure in this type of event of the magnitude to result in a material release during the molten phase of processing is judged to be no higher than a return frequency of $1 \mathrm{E}-02$ to $1 \mathrm{E}-04$ per year.

The needs of the proposed action are anticipated to be filled using more than one facility on the INL site. Dose consequence to the facility worker in an accident varies depending on the size of the room/building in which the accident occurs. Dose consequence to the public is dependent upon location of the activity and corresponding distance to the nearest site boundary where the public could be affected. Accident consequences in this document focus on molten material spill occurring at both the INTEC complex and MFC complex and use nominal values for building size and distance to the public.

To achieve the production requirements of the program, the two process lines could operate simultaneously and so for conservative analysis, double batch upsets are analyzed under accident conditions for airborne release.

\section{Overview of Accident Analysis-}

The accident analysis was conducted by using Radiological Safety Analysis Computer Program (RSAC) 7.2. RSAC 7.2 program is a radiological safety analysis tool that has been developed and used extensively at INL for calculating the doses to facility worker, collocated workers, and off-site public due to radiological releases. It has been independently verified and validated for these types of calculations.

Assumptions used for the accident analysis are as follows:

- Batch processing is $50 \mathrm{~kg}$ HALEU feedstock

- Potentially 2 batches simultaneously affected by accident

- HALEU feedstock is stored in closed containers when not in process and is therefore not considered material at risk during the analyzed accident

- Performance of HALEU in accidents (thermal stress, spill, drop, impact) follow that of uranium. The HALEU is $>99 \%$ uranium. The other elements identified are homogeneously entrained throughout the uranium matrix on ppm and ppb scale 
- This accident was analyzed as unmitigated with no credit taken for engineered controls or safety systems such as glovebox or ventilation systems

- Molten HALEU spills occur at a height of $<4 \mathrm{~m}$. Process equipment would be placed on the floor of the work area, and material would be molten only during processing

- A room/building volume of $1,700 \mathrm{~m}^{3}$ was assumed for facility worker dose calculations

- The composition of HALEU feedstock is based upon the best available information. Specific values are shown in ECAR-4310 and calculated from the maximum concentrations postulated in TEV-3537

- The nearest INL boundary is located at about 5,000 m from MFC and 14,000 m from INTEC

\section{Bounding Inhalation Dose Consequences-}

The calculation of $100 \mathrm{~kg}$ molten HALEU feedstock was postulated to be involved in a spill under assumed conditions as described above and worst case environmental conditions. Dose consequences were analyzed for the facility worker, collocated worker at $100 \mathrm{~m}$, and the public receptor located at 5,000 $\mathrm{m}$ and 14,000 $\mathrm{m}$. The analysis and results are documented in ECAR-4310, Evaluation of the Inhalation Dose Consequences for the HALEU Environmental Assessment. RSAC-7.2 was used to quantify the doses of the postulated accidents. The program is used to calculate the doses from the release of radionuclides to the atmosphere and uses the parameters of source term, plume dispersion, breathing rate, dose conversion factor for each receptor, and dry deposition in determining an estimated committed effective dose for each downwind receptor location.

Source term is calculated by multiplying material at risk quantity by damage ratio, airborne release fraction, respirable fraction, and leak path factor. The methodology for dose estimates is detailed in ECAR-4310. The results from the RSAC consequence calculations are shown in Table 7 below.

\section{Radiologic Consequences-}

Table 7. Summary of dose impacts for the highest consequence events for Alternative 1.

\begin{tabular}{|c|c|c|}
\hline Receptor & $\begin{array}{c}\text { Dose } \\
\text { Total Effective Dose (TED) }\end{array}$ & Latent Cancer Fatality (LCF) \\
\hline Facility Worker (1,700 $\mathrm{m}^{3}$ building) & $8.81(\mathrm{rem} / \mathrm{min})^{\mathrm{b}}$ & $1.03 \mathrm{E}-02^{\mathrm{d}}$ \\
\hline Collocated Worker (100 m downwind) & $997(\mathrm{mrem})^{\mathrm{c}}$ & 4.09E-04 \\
\hline Offsite Member of the Public (5,000 m downwind) & 29.4E $(\mathrm{mrem})^{\mathrm{c}}$ & $1.62 \mathrm{E}-05$ \\
\hline Offsite Member of the Public (14,000 m downwind) & $9.10(\mathrm{mrem})^{c}$ & 5.01E-06 \\
\hline $\begin{array}{l}\text { a. conservatively estimated based on ICRP Publication } 103 \\
\text { b. } 50 \mathrm{yr} \text { TED rem per minute of exposure time. If smaller r } \\
\text { adjusted to maintain worker dose below the calculat } \\
\text { c. } 50 \mathrm{yr} \text { TED millirem } \\
\text { d. Assumes a facility worker dose of } 25 \mathrm{rem} \text { and LCF factor }\end{array}$ & $\begin{array}{l}\text { alth effects } \\
\text { volumes are used, process con } \\
\text { alues } \\
4.1 \mathrm{E}-04 \text { per rem }\end{array}$ & ration and parameters would be \\
\hline
\end{tabular}




\subsubsection{Impacts of Transportation}

Transportation of HALEU feedstock, fuel alloy, and cast or clad fuel under the proposed action would occur between INL facilities on the route as shown in Figure 3, which is on roadways controlled by INL security. For transport between MFC and INTEC facilities on the INL site, an appropriate shipping container for each material would be used such as the Hot Fuel Examination Facility- 5 cask.

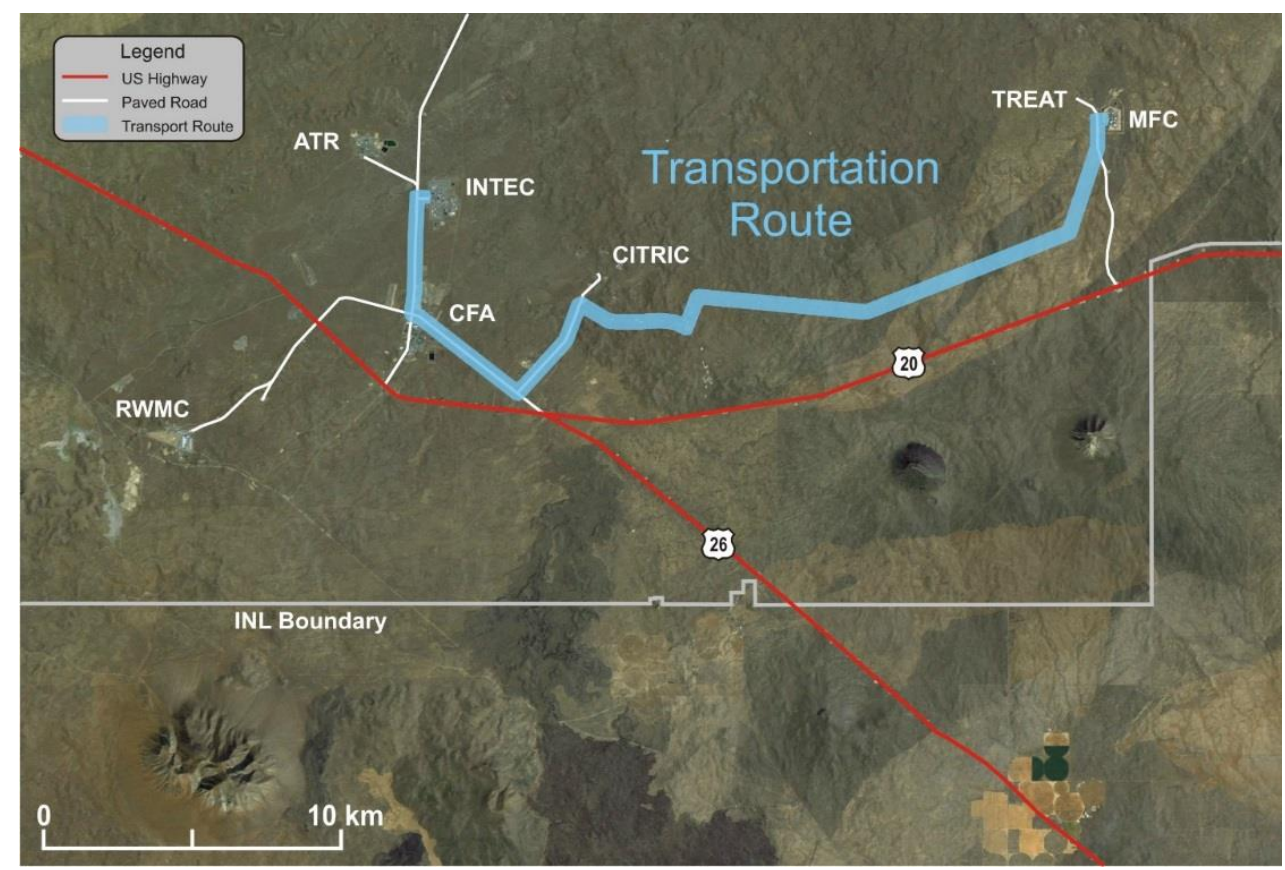

Figure 3. Transport route between INTEC and MFC.

The assessment of transportation accident consequences to workers and the public for on-site transport is addressed in, "Environmental Assessment for the Multipurpose Haul Road within Idaho National Laboratory", DOE/EA-1772 (DOE 2010). HALEU feedstock would be transported in solid form; therefore, no significant airborne release is postulated from spill and impact of solid uranium. It is not credible that a shipment could become molten under plausible transportation accidents. As shown in the previous section, for double batch size quantities, the worst-case air release of molten material HALEU feedstock, the dose consequence is expected to be substantially less than that addressed in DOE/EA-1772 (Haul Road EA). Therefore, the consequence analysis of DOE/EA-1772 is appropriate and bounding for HALEU transportation. Safety during transportation is also assured using DOE-approved transport plans, which analyze reasonable and bounding accident scenarios.

\subsubsection{Impacts of Intentional and Destructive Acts}

DOE considered Impacts of intentional acts of destruction occurring at an INL facility or during transport on INL. INL's protective force mitigates the potential for an act of sabotage occurring on site. INL routinely uses a variety of measures to mitigate the likelihood and consequences of intentional destructive acts. The DOE maintains a highly trained and equipped protective force intended to prevent attacks against and entry into the facilities. The protective force monitors and patrols site perimeters to prevent unauthorized entry. 
Access to INL roads would be restricted during transport of radioactive materials. Security measures would be in place to mitigate the likelihood and consequences of sabotage. Transportation crewmembers would be screened for behavioral and substance abuse issues and would receive safety and security training. Crewmembers would conduct a thorough inspection of vehicles and loads before transport. During transport, crewmembers have a means of communication and immediately report suspicious activity encountered while in route.

Accident analyses for the proposed action are evaluated based on conservative assumptions using parameters resulting in the highest postulated dose to workers and public receptors, therefore, any acts of sabotage, should they occur, would be expected to result in consequences that would be bounded by the results of accident scenarios detailed above.

\subsubsection{Sustainability}

The only anticipated sources of greenhouse gas (GHG) emissions would be from a diesel backup generator. Emissions from the transport of nuclear material would also be included. BEA uses 100\% renewable diesel fuel, which would result in ' 0 ' metric tons carbon dioxide equivalent (MT CO2e) of anthropogenic GHG emissions. If $100 \%$ renewable diesel is not available, the total anthropogenic GHG emissions are estimated to be less than 0.5 MT CO2e, assuming heavy-duty vehicle burning 100\% diesel and taking 20 one-way trips at 20 miles per trip.

\subsubsection{Cumulative Impacts}

DOE reviewed the resources at risk; geographic boundaries; past, present, and reasonably foreseeable future actions; and baseline information in determining the significance of cumulative impacts. The review was assessed for construction, transportation, normal operations, and potential impacts of accidents. Conclusions are as follows:

- Cumulative impacts to historic properties cannot be evaluated until Section 106 has been completed. Section 106 under the proposed action alternatives has been deferred; as such, cumulative impacts to historic properties would be evaluated under the MOA and associated stipulations identified in the NEPA decision for completion of Section 106. (see Section 4.1.1)

- The proposed action would not create new facility or building footprint; therefore, there would be no or negligible cumulative impacts to biological resources. There may be low short-term impact to INL's ecological resources. (see Section 4.1.2.3)

- During normal operations, cumulative radiologic, waste generating, or sustainability impacts would be minimal. Radiologic releases during normal operations would not result in adverse health impacts. Additional waste volumes would be small compared to current disposal volumes at INL. Additional GHG emissions would be negligible compared to INL Site-wide amounts (see Section 4.1.6).

The maximum total annual estimated dose from atmospheric emissions to a maximally exposed off-site individual reported for INL compliance in year 2017 is 0.008 mrem (DOE ID 2018). Inclusion of the conservatively estimated maximum annual dose contribution from HALEU fuel production of $1.6 \mathrm{mrem}$ (Alternative $1 \mathrm{~b}$ ) would result in a total annual estimated dose at Frenchman's Cabin of $1.61 \mathrm{mrem}$. The estimated annual dose of 0.74 mrem (Alternative 1a) would result in a total annual dose estimate of $0.75 \mathrm{mrem}$. Although the Alternative $1 \mathrm{a}$ and $1 \mathrm{~b}$ doses from HALEU fuel production are much larger than the dose from current emissions, the doses from 
HALEU fuel production are based on conservative emission estimates that take no credit for mitigation. The actual emissions and doses are expected to be much less.

There are several proposed projects at the INL Site that DOE considers reasonably foreseeable that would include radiological emissions that could contribute to cumulative impacts. Those that DOE reviewed include:

- Remote-Handled LLW Disposal Facility

- Plutonium-238 Production for Radioisotope Power Systems

- Recapitalization of Infrastructure Supporting Naval Spent Nuclear Fuel Handling

- Resumption of Transient Testing using the TREAT facility

- Radiological Response Training Ranges

- National Security Test Range

Table 8 presents the estimated dose from each reasonably foreseeable project to a MEI. Most are screeninglevel dose estimates which means the analysis used conservative assumptions (e.g. no mitigation) to bound the dose estimate. In addition, some projects estimate dose at the nearest off-site public receptor location which may be several miles from Frenchman's Cabin. For example, the location of the public receptor dose presented for the National Security Test Range is near the INL Site northeast boundary, more than 38 miles from the INL MEI location at Frenchman's Cabin. If the doses for each project are conservatively assumed to occur at Frenchman's Cabin (which they do not), the total dose from reasonably foreseeable projects, including HALEU fuel production, is $1.67 \mathrm{mrem} / \mathrm{yr}$. If combined with the current maximum total annual estimated dose reported for INL compliance (0.008 mrem in 2017), the dose from current and reasonably foreseeable future actions on the INL Site would be 1.68 mrem as indicated in Table 8. Although the actual dose is expected to be much less, this estimated dose is still much lower than the 10 mrem annual dose standard.

The potential additive impacts from implementing Alternative $1 \mathrm{a}$ or $1 \mathrm{~b}$ for HALEU fuel production are determined to be collectively small and would have little impact to reasonably foreseeable future actions or current operations. 


\subsection{Summary of Environmental Impacts}

Table 9 summarizes impacts of the proposed action for air, cultural and biological resources and waste generation and management.

Table 9. Summary of environmental impacts. ${ }^{a}$

\begin{tabular}{|c|c|}
\hline Resource & Alternative \#1: Proposed Action \\
\hline & Impacts -- Construction \\
\hline \multirow[t]{2}{*}{$\begin{array}{l}\text { Constructions } \\
\text { (Section 4.1.1) }\end{array}$} & $\begin{array}{l}\text { - Project activities may generate fugitive dust as the result of construction or modification due to } \\
\text { possible soil disturbance or excavation activities. } \\
\text { - Materials containing asbestos could be disturbed. } \\
\text { - INL has not determined which buildings at either MFC or INTEC would be used under the proposed } \\
\text { action; as such, DOE would evaluate impacts to historic properties before making the NEPA decision, } \\
\text { resulting in deferment of Section } 106 \text { as per } 36 \text { CFR } 800.14(b)(1)(i i) . \\
\text { - The modifications for fuel fabrication would generate non-radioactive electronic waste, scrap metal, } \\
\text { and other construction-related debris. Construction debris, electronic waste, and scrap metal would } \\
\text { be recycled to the extent possible. }\end{array}$ \\
\hline & Impacts - Normal Operations \\
\hline $\begin{array}{l}\text { Non-Radiologic } \\
\text { Atmospheric } \\
\text { Impacts - } \\
\text { chemical } \\
\text { pollutants } \\
\text { (Section 4.1.2.1) }\end{array}$ & - Nonradiological emissions would be minimal during operational stages. \\
\hline $\begin{array}{l}\text { Atmospheric } \\
\text { Pathway } \\
\text { (Section 4.1.2.1 }\end{array}$ & $\begin{array}{l}\text { - A conservative assessment of radionuclide releases during anticipated normal operations indicates } \\
\text { cumulative doses from all INL sources would be well below the } 10 \text { mrem/year dose standard for a } \\
\text { member of the public at the INL MEI location (see Section 4.1.7). Estimated doses to collocated } \\
\text { workers would be well below the 5,000-mrem dose standard. }\end{array}$ \\
\hline $\begin{array}{l}\text { Waste } \\
\text { Generation } \\
\text { (Section 4.1.2.2 }\end{array}$ & $\begin{array}{l}\text { - The volume of various LLW generated during routine operations are expected to be less than } 20 \mathrm{~m}^{3} \\
\text { per year (based on past generation rates at MFC). The additional LLW disposal from these } \\
\text { operations would represent less than a } 2.5 \% \text { increase in the volume sent to off-site disposal facilities } \\
\text { each year. } \\
\text { - Less than } 1 \mathrm{~m}^{3} \text { of transuranic waste is expected to be generated. } \\
\text { - The materials and fuel specimens proposed for analysis would not be appreciably different from } \\
\text { current testing. }\end{array}$ \\
\hline $\begin{array}{l}\text { Biological } \\
\text { Resources } \\
\text { (Section 4.1.2.3) }\end{array}$ & $\begin{array}{l}\text { - Terrestrial animals are the limiting species and modeling shows that the soil concentration/BCG } \\
\text { ratios do not cumulatively exceed } 1 \text { for terrestrial animals or plants, thus, the limits established for } \\
\text { protection of terrestrial biota would not be exceeded for either alternative. }\end{array}$ \\
\hline \multicolumn{2}{|r|}{ Impacts - Potential Accidents } \\
\hline $\begin{array}{c}\text { Accidents } \\
\text { (Section 4.1.3) }\end{array}$ & $\begin{array}{l}\text { - The committed dose to facility workers from the most severe postulated accident is conservatively } \\
\text { estimated to be } 8.81 \text { rem/min of exposure time. Facility worker dose is further reduced by } \\
\text { engineered and administrative controls and procedures and by using protective equipment. } \\
\text { - Committed dose estimates for collocated workers would be } 997 \text { millirem and would result in } 4.09 \mathrm{E}- \\
04 \text { (or } 1 \text { chance in } 2400 \text { ) LCFs. Estimated dose to the public at } 5,000 \text { m and } 14,000 \text { m would be } 29.4 \\
\text { millirem and } 9.1 \text { millirem respectively with corresponding LCFs estimated at } 1.62 \mathrm{E}-05 \text { ( } 1 \text { in } 62,000) \\
\text { and } 5.01 \mathrm{E}-6 \text { ( } 1 \text { in 200,000). These consequences would likewise be reduced by applying engineered } \\
\text { and administrative controls. }\end{array}$ \\
\hline \multicolumn{2}{|r|}{ Impacts -- Transportation } \\
\hline $\begin{array}{l}\text { Transportation } \\
\text { (Section 4.1.4) }\end{array}$ & $\begin{array}{l}\text { - HALEU feedstock would be transported in solid form; therefore, no significant airborne release is } \\
\text { postulated from spill and impact of solid uranium. } \\
\text { - The consequence analysis of DOE/EA-1772 is appropriate and bounding for HALEU transportation. }\end{array}$ \\
\hline
\end{tabular}




\begin{tabular}{|c|c|}
\hline Resource & Alternative \#1: Proposed Action \\
\hline \multicolumn{2}{|c|}{ Intentional and Destructive Acts } \\
\hline $\begin{array}{c}\text { Destructive Acts } \\
\text { (Section 4.1.5) }\end{array}$ & $\begin{array}{c}\text { INL routinely uses a variety of measures to mitigate the likelihood and consequences of intentional } \\
\text { destructive acts. }\end{array}$ \\
\hline a. Alternative \#2 'No Action' results in no change to environmental impact from current operations. \\
\hline
\end{tabular}




\section{PERMITS AND REGULATORY REQUIREMENTS}

Each alternative would be required to adhere to federal, state, and local regulations and obtain appropriate permits before constructing, modifying, or operating facilities, equipment, or processes. Below is a list of federal, state, and local regulations and permits that either of the alternatives may be required to adhere to or to obtain. The 'No Action' alternative complies with permits and applicable regulatory requirements. DOE would be responsible for identifying a comprehensive list of applicable regulations and permits for the selected actions. Activities that affect, or may affect, the safety of DOE nuclear facilities must also comply with the requirements of 10 CFR 830, Nuclear Safety Management.

\section{Air}

Radiologic air emissions from the INL must meet the EPA limit of $10 \mathrm{mrem} / \mathrm{year}$ for demonstration of compliance with "National Environmental Standards for Emissions of Radionuclides Other Than Radon from Department of Energy Facilities" (40 CFR 61, Subpart H). In addition, because each processing facility would exceed the $0.1 \mathrm{mrem} / \mathrm{yr}$ limit, each facility may require an 'Application to Construct' under 40 CFR 61.96 and a state PTC under IDAPA 58.01.01.200 for a radiological source requiring a continuous stack monitor to be built per ANSI N13.1 (2011).

Emissions of hazardous air pollutants, criteria pollutants and state toxic air pollutants would be evaluated for compliance with Permit to Construct P-2015-0023, INL 'Permit to Construct' and Facility Emission Cap. If emissions are under the facility wide limits of Permit Condition 2.2 and comply with the Notice and Recordkeeping of Ambient Concentration Estimates of Permit Condition 2.6 no permit revision would be required. If the ambient concentration exceeds significant contribution levels of IDAPA 58.01.01.006.109, a separate PTC would be required.

\section{Biological}

In analyzing the potential ecological impacts of the action alternative for the proposed action, DOE has followed the requirements of the Endangered Species Act (16 USC $\$ 1531$ et seq.) and has reviewed the most current lists for threatened and endangered plant and animal species. Other federal laws that could apply include: the Fish and Wildlife Coordination Act (16 USC $\S 661$ et seq.), Bald and Golden Eagle Protection Act (16 USC § 668), and the Migratory Bird Treaty Act (16 USC § 715-715s).

\section{Cultural}

Cultural resources are managed at the INL Site according to a tailored approach outlined in INL's Cultural Resource Management Plan (DOE-ID 2016) and corresponding Programmatic Agreement executed among DOE, the Idaho SHPO, and the Advisory Council on Historic Preservation. Shoshone-Bannock tribal interests in INL resources and activities are addressed in an Agreement in Principle between DOE and the Shoshone-Bannock Tribes.

Section 106 of the National Historic Preservation Act (NHPA) directs any federal agency undertaking or licensing any activity, to "prior to the approval of the expenditure of any federal funds on the undertaking or prior to the issuance of any license, as the case may be, [to] take into account the effect of the undertaking on any district, site, building, structure or object that is included in or eligible for inclusion in the National Register." To assess the impact of such an undertaking, an agency must know whether any affected district, site, building, structure, or object is eligible for the NRHP. (Section 110 of the NHPA requires a federal agency to assume responsibility 
for historic properties it owns or controls. Historic properties must be identified, evaluated, documented, and nominated to the NRHP, if appropriate. Thus, Section 110 obliges an agency to preserve its historic properties and manage those properties in compliance with Section 106.

DOE has negotiated a following process for deferring Section 106 under the proposed action for Alternative 1 with the Idaho SHPO, per 36 CFR 800.14(b )(1)(ii). The following process was outlined in a letter from DOE to the Idaho SHPO on October 10, 2018:

1) The Idaho SHPO will be allowed the opportunity to review the language in the EA regarding deferring Section 106 once the document has been made available for public comment, as per 36 CFR 800.8(c)(2)(i);

2) DOE will prepare a MOA outlining how the Section 106 process will be completed, once determinations are made regarding the specific buildings involved in the undertaking.

3) The MOA will be signed prior to the NEPA decision. The NEPA decision will include stipulations for completing the Section 106 process.

\section{Sustainability}

Executive Order 13834 "Efficient Federal Operations;" DOE's 2016 Strategic Sustainability Performance Plan; and DOE Order 436.1, "Departmental Sustainability" contains requirements and assign responsibilities for managing sustainability within DOE to carryout missions in a sustainable manner. These requirements also include provisions to institute wholesale cultural change to factor sustainability and GHG reductions into DOE decisions, and to achieve DOE's sustainability goals established in its Strategic Sustainability Performance Plan.

Per DOE's 2016 Strategic Sustainability Performance Plan Goal 2, alterations or renovations of buildings greater than 5,000 GSF must comply with the Guiding Principles. There are 26 Guiding Principles required for a building to meet compliance. Some are at no cost (e.g., non-smoking policy) and others require investments (e.g., water, gas, electricity meter installations). Executive Order 13834 states that new construction and major renovations conform to applicable building energy efficiency requirements and sustainable design principles; consider building efficiency when renewing or entering into leases; practice using and optimizing space; and annually assess and report on building conformance to sustainability metrics. These requirements would be incorporated and addressed, where applicable.

\section{Nuclear Safety}

10 CFR 830 sets forth requirements that must be implemented in a manner that gives reasonable assurance of adequate protection of workers, the public, and the environment from adverse consequences, taking into account the work to be performed and the associated hazards. 


\section{COORDINATION AND CONSULTATION DURING EA PREPARATION}

Shoshone-Bannock Tribes

DOE briefed Shoshone-Bannock Tribes' staff on the HALEU EA and project on September 5 and October 24, 2018, and the Fort Hall Business Council on October 30, 2018.

DOE briefed the Heritage Tribal Office on October 10, 2018 on the HALEU Project, the plan to defer Section 106, and the Memorandum of Agreement.

\section{INL Oversight Office}

DOE briefed Kerry Martin (State of Idaho's INL Oversight Office Manager), her staff, and Mark Clough (Idaho DEQ) on the HALEU EA on October 16, 2018.

Idaho State Historic Preservation Office

DOE has negotiated a process for deferring Section 106 under the proposed action for Alternative 1 with the Idaho SHPO, per 36 CFR 800.14(b )(1)(ii).

Congressional

DOE briefed staff members of Sen Risch, Sen Crapo, and Congressman Simpson on October 18, 2018. 


\section{REFERENCES}

ECAR-3533, 2018, "Assessment of Potential Dose and Environmental Impacts from Proposed Testing at the INL Radiological Response Training Range," Revision 2, A.J. Sondrup, December 2018.

ECAR-3565. 2018, "Assessment of Potential Dose and Environmental Impacts from Proposed Testing at the INL National Security Test Range," Revision 1, A.J. Sondrup, December 2018.

ECAR-4310, 2018, "Evaluation of the Inhalation Dose Consequences for the HALEU Environmental Assessment," Revision 0, B. Christensen, October 2018.

ECAR-4321, 2018, "Evaluation of Impacts from Radiological Air Emissions for the HALEU Environmental Assessment," Revision 0, A.J. Sondrup, October 2018.

ICRP-68, "Dose Coefficients for Intakes of Radionuclides by Workers," International Commission on Radiological Protection," 1994.

ICRP-72, "Age-dependent Doses from Intakes of Radionuclides," International Commission on Radiological Protection, 1996.

McFarlane, H. F., 2001, "The Defense Programs Origin of Transuranic Waste at ANL-W", ANL-NT-192, Argonne National Laboratory - West, November 2001.

TEV-3537, 2018, "Isotopic Characterization of HALEU from EBR-II Drive Fuel Processing," Revision 0, D. Vaden, October 2018.

U.S. Department of Energy Idaho Operations Office (DOE-ID), 1994, "Track 2 Sites: Guidance for Assessing Low Probability Hazard Sites at the INEL," DOE/ID-10389, August 1994.

U.S. Department of Energy (DOE), 2000, "Final Environmental Impact Statement for the Treatment and Management of Sodium-Bonded Spent Nuclear Fuel, Volume 1," U.S. Department of Energy, Office of Nuclear Energy, Science and Technology, Washington, DC , DOE/EIS-306, July 2000.

U.S. Department of Energy (DOE), 2010, “Idaho National Laboratory Radiological Response Training Range Environmental Assessment," DOE/EA-1776, U.S. Department of Energy, October 2010.

U.S. Department of Energy (DOE), 2011, "Environmental Assessment for the Replacement Capability for Disposal of Remote-Handled Low-Level Radioactive Waste Generated at the Department of Energy's Idaho Site," DOE/EA1793, U.S. Department of Energy, December 2011.

U.S. Department of Energy (DOE), 2013a, "Final Site-Wide Environmental Impact Statement for the Continued Operation of the DOE/National Nuclear Security Administration Nevada National Security Site and Off-Site Locations in the State of Nevada," DOE/EIS-0426, February, 2013

U.S. Department of Energy (DOE), 2013b, "Supplemental Analysis for the Nuclear Infrastructure Programmatic Environmental Impact Statement for Plutonium-238 Production for Radioisotope Power Systems," DOE/EIS0310-SA-02, U.S. Department of Energy, Washington, D.C. September 2013.

U.S. Department of Energy (DOE), 2016, "Final Environmental Impact Statement for the Recapitalization of Infrastructure Supporting Naval Spent Nuclear Fuel Handling at the Idaho National Laboratory," DOE/EIS-0453-F, Appendix D, U.S. Department of Energy, October 2016.

U.S. Department of Energy (DOE), 2014, "Environmental Assessment for the Resumption of Transient Testing of Nuclear Fuels and Materials," DOE/EA-1954, U.S. Department of Energy, February 2014. 
U.S. Department of Energy Idaho Operations Office (DOE-ID), 2016, "Idaho National Laboratory Cultural Resource Management Plan," U.S. Department of Energy - Idaho Operations Office, DOE/ID-10997, June 2016.

U.S. Department of Energy Idaho Operations Office (DOE-ID), 2018, "National Emission Standards for Hazardous Air Pollutants - Calendar Year 2017 INL Report for Radionuclides", DOE/ID-11441, June 2018.

U.S. Department of Energy (DOE), 2010, "Environmental Assessment for the Multipurpose Haul road Within the Idaho National Laboratory Site," DOE/EA-1772, August 2010.

VFS-ID-ESER-NEPA-044, 2018, "Analysis of Radiological Impacts to Terrestrial Biota in Support of Environmental Assessment for Use of DOE-Owned High-Assay Low-Enriched Uranium Stored at Idaho National Laboratory, Revision 0," M.J. Case and D. Halford, Veolia Nuclear Solutions - Federal Services, October 2018.

\section{Code of Federal Regulations Referenced in this EA}

10 CFR 830 - Nuclear Safety Management

10 CFR 835.202 -- Occupational dose limits for general employees

36 CFR 800.14(b)(1)(ii) - Federal Agency Program Alternatives, Use of Programmatic Agreements, Advisory Council on Historic Preservation

36 CFR 800.8(c)(2)(i) - Coordination with the National Environmental Policy Act, Review of Environmental Documents.

40 CFR 61 Appendix D - Methods for Estimating Radionuclide Emission

40 CFR Part 61, Subpart H - National Emission Standards for Emissions of Radionuclides other than Radon from Department of Energy Facilities

40 CFR 61.96, Subpart H - Applications to construct or modify

40 CFR Part 191 - Environmental Radiation Protection Standards for Management and Disposal of Spent Nuclear Fuel, High-Level and Transuranic Radioactive Wastes.

40 CFR 1500.2[e] - Council on Environmental Quality, Purpose, Policy, and Mandates 


\section{APPENDIX A - Comment Responses}

The formal comment period for the Draft EA for the 'Use of DOE-Owned High-Assay Low-Enriched Uranium ended on November 30, 2018. DOE received several comments from interested parties and groups. DOE has reprinted these comments verbatim as received. The following pages contain DOE's responses to the comments. This document is being prepared as an appendix to the Final EA and DOE will send copies to those individuals and groups who gave DOE comments. This document will also be available online and to other interested parties upon request. Comments are organized by commenter in alphabetical order (see Table A-1).

Items added to the EA are called out in individual comments. 


\section{Commenters}

Table A-1. List of commenters, commenters affiliation (if any), and page number of comment response.

\begin{tabular}{|c|c|c|c|}
\hline $\begin{array}{c}\text { Comment } \\
\text { \#s }\end{array}$ & Commenter & Commenter (affiliation, if any) & $\begin{array}{l}\text { Page \# for } \\
\text { Response }\end{array}$ \\
\hline 1 & $\begin{array}{l}\text { Aref Alexander Adibi, Real } \\
\text { Estate Broker }\end{array}$ & Century 21 , Northwest, Krikland, WA & 39 \\
\hline 2 & Nima Ashkeboussi & Nuclear Energy Institute & 40 \\
\hline 3 & $\begin{array}{l}\text { Larae Bill, Cultural Resource } \\
\text { Specialist }\end{array}$ & The Shoshone-Bannock Tribes & 41 \\
\hline 4 & $\begin{array}{l}\text { Beatrice Brailsford, Nuclear } \\
\text { Program Director }\end{array}$ & Snake River Alliance & 45 \\
\hline 5 & Chuck Broscious, President & Environmental Defense Institute & 48 \\
\hline 6 & Jason Charles & Self & 53 \\
\hline 7 & Benjamin Cox & Self & 53 \\
\hline 8 & Suketu Gandi & Self & 54 \\
\hline 9 & Peter Hastings, Vice President & Kairos Power & 55 \\
\hline 10 & Lars Jorgensen, CEO & ThorCon US & 56 \\
\hline 11 & Edwin Lyman, Senior Scientist & Union of Concerned Scientists & 58 \\
\hline 12 & Bob McGarn & Self & 59 \\
\hline 13 & $\begin{array}{l}\text { Rich Powell, Executive Director } \\
\text { David Blee, President and CEO }\end{array}$ & $\begin{array}{l}\text { ClearPath } \\
\text { U.S. Nuclear Industry Council }\end{array}$ & 60 \\
\hline 14 & Peter Rickards & Self & 62 \\
\hline 15 & Ann Rydalch & Self & 66 \\
\hline 16 & Abhijit Sengupta & Self & 67 \\
\hline 17 & Tami Thatcher & Self & 68 \\
\hline 18 & Noy Xayavong & Self & 83 \\
\hline
\end{tabular}


Table A-2. DOE's response to comments on the draft EA sorted by commenter.

\section{Aref Alexander Adibi, Real Estate Broker, Century 21}

Comment(s) 1:

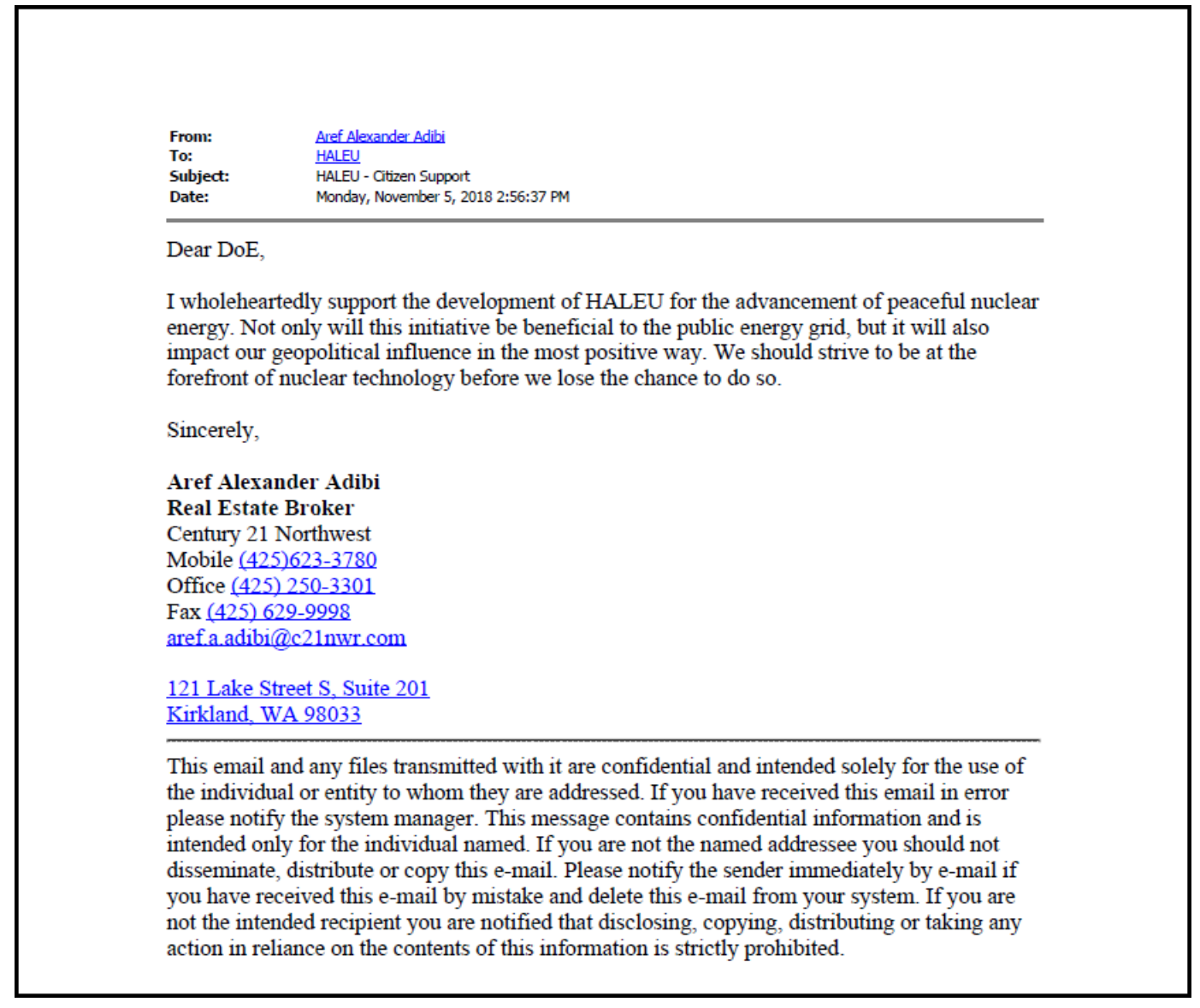

Response(s) 1: Mr. Adibi, DOE acknowledges your comment supporting the proposed action. Thank you. 
Table A-2. DOE's response to comments on the draft EA sorted by commenter.

\section{Nima Ashkeboussi, Nuclear Energy Institute}

\section{Comment(s) 2:}

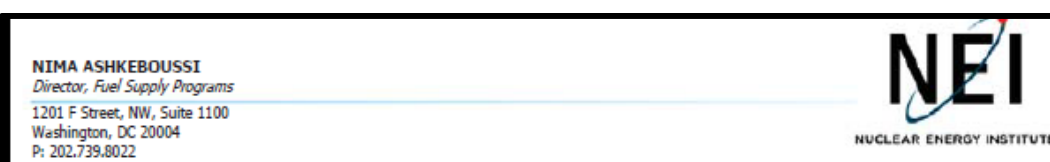

November 30, 2018

Page 2

nxa@nei.org

nei.rorg

November 30, 2018

of new enrichment capacity, or the recycling of spent high-enriched fuel that could that could be converted

to HALEU.

Delivered VIA Email (HALEU@id.doe.gov)

Mr. Dave Herin

Idaho Operations Office

U.S. Department of Energy

1955 Fremont Avenue

Idaho Falls, ID 83415-1222

Thank you for your consideration of these comments. Please contact me if you have any questions.

Sincerely,

Nima Astkbous.

Nima Ashkeboussi

Subject: Submittal of Comments on the Draft Environmental Assessment for the Use of DOE-Owned High Assay Low-Enriched Uranium Stored at INL (DOE/EA-2087)

Dear Mr. Herin:

On behalf of the Nuclear Energy Institute's ${ }^{1}$ (NEI) members, we welcome the opportunity to comment on the Department of Energy's (DOE) "Draft Environmental Assessment for the Use of DOE-Owned High-Assay Low-Enriched Uranium (HALEU) Stored at Idaho National Laboratory" (October 2018). We fully support the Department's efforts to produce 10 Metric Tons of HALEU in support of advanced reactor development,

including making the material available for use as fuel by the commercial nuclear industry. NEI appreciates the Department's leadership and commitment to helping preserve and strengthen the civil nuclear energy sector. The Department's continued support for the development of innovative technologies, including the next generation of advanced reactors, and advanced fuels for the existing fleet of reactors, will help ensure that nuclear power continues to bolster America's national security by providing the dominant source of resilient, carbon-free power in the United States. As work on this project progresses, we encourage the Department to work closely with industry to characterize the material being produced, including any material impurities.

In a July 5, 2018 letter to Energy Secretary Perry, NE outlined the domestic commercial industry's need for a supply of HALEU for future advanced reactors. Currently there is no commercial supply of HALE available and early DOE support, including this effort, is critical to accelerate the development of the fuel supply infiastructure by providing an interim supply of HALEU fuel. In addition to this effort, we continue to encourage DOE to examine other material that could be used for an interim HALEU supply, including use of the inventory of high-enriched uranium that could be downblended to HALEU, support for the development

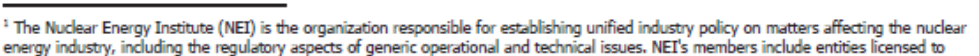

energy industry, induding the regulastory aspects of generic operational and technical issues. NEI's members include entities licensed to

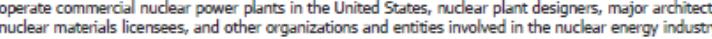

Response(s) 2: Ms. Ashkeboussi, thank you for your comments. Please refer to the numbered comments and corresponding numbered responses. 
Table A-2. DOE's response to comments on the draft EA sorted by commenter.

Larae Bill, Cultural Resource Specialist, The Shoshone-Bannock Tribes

Comment(s) 3 - 8:

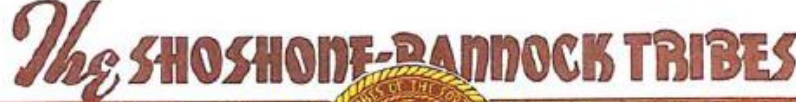

\section{Cultural Resources/Heritage Tribal Offico}

(Herol

anguage \& Cultural Preservation Department

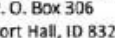

Phone: $(200) 236-10$

$(208) 236-1081$
$(208) 236-1084$

Email: csmith@strtibescom

ibillestrtibes.com

November 30,2018

RE: Shoshone-Bannock Tribes' Comments on the Draft Environmental Assessment for the Use of DOEOwned High Assay Low-Enriched U ranium Stored at INL (DOE/EA-2087)

Dave Herrin

U.S. Department of Energ

1955 Fremont Avenue

Idaho Falls, ID $83415-1222$

Dear Mr. Herrin

The Shoshone-Bannock Tribes Tribal Department of Energy (T/DOE) and the Cultural Resources/Heritage Tribs The Office (CR/HoTO) appreciates the opportunity to provide technical comments to the Draft
Assessment for the Use of DOE-Owned High Assay Low-Enriched Uranium Siored at INL.

The INL is within the inherent ancestral territory of the Shoshone and Bannock peoples. The INL is part of a major corridor to the Salmon River, the Lemhi Range, Pahsimeroi Range, the bitterroot valleys, and critical habitats for bison, deer, elk and other wild game in Montana and Idaho. This land has provided subsistence-including plants, roots, fish, wildlife, and minerals-since time immemorial. And there are countless archeeological sites at INL such as historic/pre-contact campsites and living areas. Hunting and gathering occurred on the INL as evidenced by the large numbers of archaeological sites left by the original inhabitants-the ancestors of the Seashone and Bann people today. Family bands mign (sagebrush people), Yahan-Dika (ground hog eaters), to name a few bands The land they once occupied is the legacy of the Shoshone-Bannock Tribes today, and it is only one region of our larger inherent ancestral territory. Our ancestral Tribal traditional and cultural practices remain alive today through the continual use of this area as a corridor to our inherent ancestral arcas and subsistence resources.

The Shoshone-Bannock Tribes have a unique relationship with the DOE. The Tribes are a sovereign nation, and we

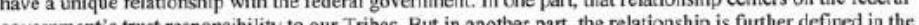
Tribal resources and inherent territories is quite different than DOE's obligations to the public, to interested parties, or to stakeholders. Among other things, the Tribes are supposed have a first-hand review of any environmental ocuments before the public and be afforded the opportunity to provide comments before public review. The DOE did not provide sufficient time for a Tribal review before releasing this Draft EA for public comment.
In addition, our Tribes have several concerns about the procedures followed in the NHPA process and specific concerns about the contents of the Draft EA.

Cultural Resources

The Draft EA reads:

1) The Idaho SHPO will be allowed the opportunity to review the language in the EA regarding defernent of Section 106 once the document has been made available for public comm

2) DOE will prepare a MOA outlining how the Section 106 process will be completed, once determinations are made regarding the specific buildings involved in the undertaking.

2) The MOA will be signed prior to making the NEPA decision. The NEPA decision will include stipulations for completing the Section 106 process.

Although this HALEU Project will not involve ground-disturbing activities that could impact Tribal archaeological resources at the INL, the Draft EA states that no decision is made as to which building would be utilized for the

attional Historic Preservation Act is significant and deferment is unacceptable. Any impacts to historic

properties must be analyzed before the issuance of the Draft EA. It seems that the Section 106 process for this Draft EA is backward and being pushed on a fast track, which seems to be the norm for DOE. With regard to the development of a MOA between DOE and the State Historic Preservation Office, the Tribes shall be included in the review of the MOA and also be included as a Concuring Party.

The DOE will be applying for air emissions pernits with Idalio DEQ and US EPA. Nonradiological enissions are expected to be below state and federal limits. Radiological emissions may deliver a larger impact but also are expected to be below EPA standards

While the Tribes are concerned with any additional radiological emissions at INL, we are especially concemed with how radiological emissions will impact Tribal sacred sites at $\mathrm{NL}$ and Tribal members who may use those areas. In Figure 2 of the Draft EA, the DOE provided a map of actual and hypothetical public receptor sites. And Table 2

included in the EA.

We might expect that the Total ED for Middle Butte would be slightly less than it is for the "Residence Neares MFC." At this site, Altemative lb would create less Total ED—and presumably less ED at Middle Butte.

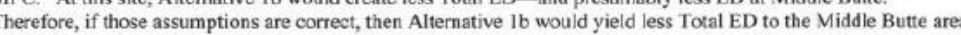
All else being equal, the Tribes would prefer the alternative that creates the least amount of radiological exposure to

Air Emissions

Air Emission and deposition impacls in the northeast direction were not fully disclosed in the Draft EA. Under Table 4, the Draft EA states that "For both MFC and INTEC, maximum deposition occurs $200 \mathrm{~m}$ from the stack in the $\mathrm{Ne}$ dircetion. But no data are provided that shous depostion beyond $200 \mathrm{~m}$. Certainly, deposition occurs beyond the $200-\mathrm{m}$ mark. We suggest extending the atmospheric transport modef to include the fut range of additional areas outside of INL boundary may have elevated levels of radionclide deposition, and what their 


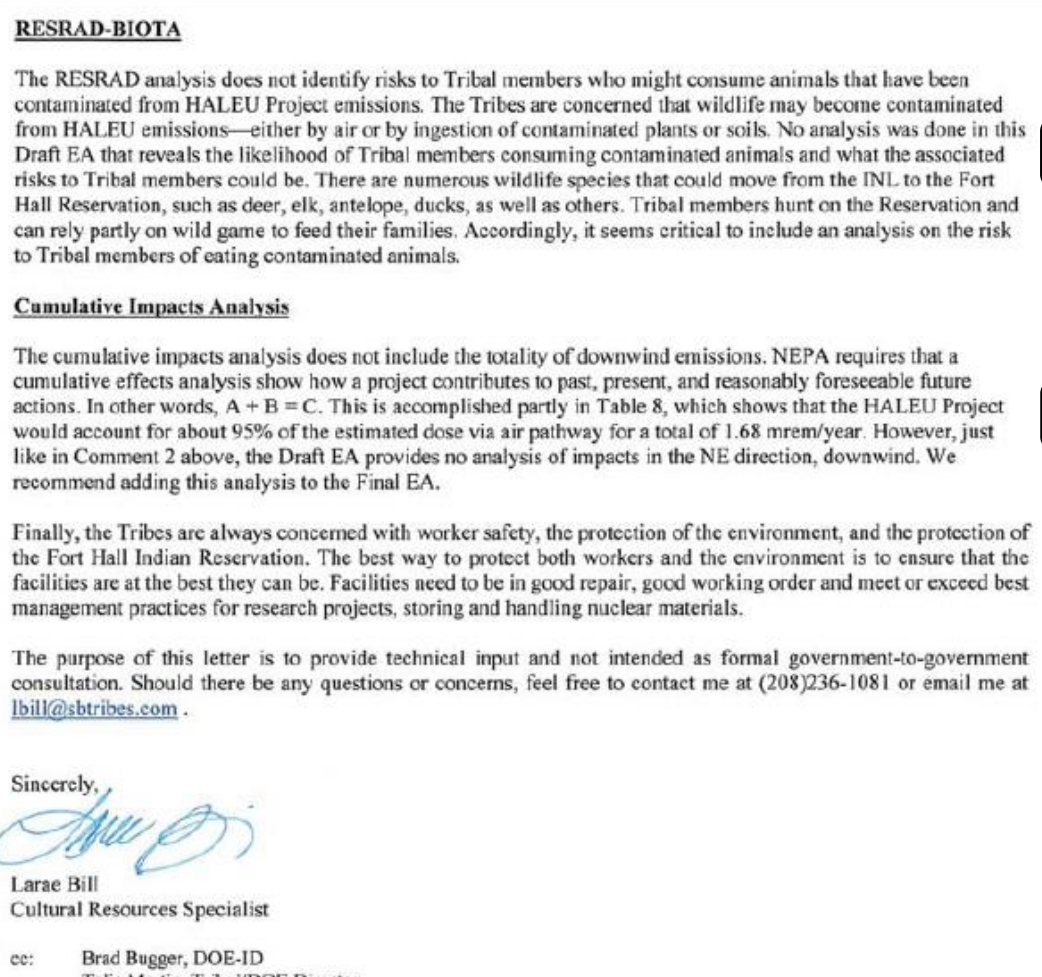

The purpose of this letter is to provide technical input and not intended as formal government-to-government consultation. Should there be any questions or concerns, feel free to contact me at (208)236-1081 or email me at 1bill@sbtribes.com.

Sincerely,

Larae Bil

Cultural Resources Specialist

cc: Brad Bugger, DOE-ID

Response(s) 3 - 8: Ms. Bill, thank you for your comments. Please refer to the numbered comments and corresponding numbered responses.

3. The Department of Energy recognizes the unique relationship we have with the Shoshone-Bannock Tribes, who are a sovereign entity and with whom we have a trust responsibility to protect their people, cultural resources, ancestral homeland and current reservation land. DOE reached out to Tribal subject matter experts immediately after the EA Determination for this project was signed, and offered Tribal staff a briefing on the scope of the EA before it was prepared. This briefing was carried out with Tribal staff on September 5, 2018 in Idaho Falls.

After most of the substantial work on the EA was completed, DOE again offered the Tribal staff a briefing to bring them up to speed on the likely results of the analysis. This briefing was given to Tribal staff on October 24, 2018 in Fort Hall. Finally, as work on the EA was completed, DOE offered the Fort Hall Business Council a detailed briefing on the scope and findings of the EA, which was carried out at Fort Hall on October 30. 2018, the day before the draft EA was released for public review and comment.

DOE believes these sincere attempts at early and thorough communications with the Tribes more than fulfill the requirements of the Agreement in Principle between the agency and the Tribes, which states: "(DOE agrees to the following) Arrange and give presentations or briefings to Tribal audiences for those NEPA 
Table A-2. DOE's response to comments on the draft EA sorted by commenter.

activities that may affect the Tribes, and will facilitate the interface with DOE-HQ. The Tribes will have opportunity to participate in the normal public process leading to issuance of final EAs and EISs."

4. Response: 36 CFR Part 800, Protection of Historic Properties, allows federal agencies to defer final identification and evaluation of historic properties if specifically provided for in a formal agreement or in the documents used by an agency official to comply with NEPA. The specific buildings that would be used for the project have not yet been determined and, therefore, the effects on historic properties cannot be fully determined prior to approval of the undertaking (i.e. making a NEPA decision). DOE consulted with the Idaho State Historic Preservation Office (SHPO) and negotiated a process to defer section 106 and a draft memorandum of agreement (MOA) was developed to outline how the section 106 process would be completed once determinations are made regarding specific buildings involved in the undertaking. DOE is committed to meeting its legal obligations to complete the section 106 process. DOE will make a modification to the final EA that identifies the significance of the buildings under consideration, potential modifications that may be needed to the buildings, and the types of associated mitigative actions that may be taken. DOE formally notified the Honorable Chairman Nathan Small, Fort Hall Business Council, on October 11, 2018, of the request to SHPO to defer section 106 (CLN190064) and formally transmitted the draft MOA to Honorable Chairman Small on October 30, 2018, for review (CLN190149). DOE will modify the MOA to add the Tribes to the signatory page as a Concurring Party and transmit the final MOA to the Tribes for signature.

5. The EA contains calculations of dose to public receptors during normal operations (unmitigated dose) at several receptor locations including Atomic City. Middle Butte is in the pathway between MFC and Atomic City. DOE understands Middle Butte is a Tribal sacred site and that Tribal members go to Middle Butte for ceremonial activities. In evaluating potential effective dose to public receptors, the draft EA estimates the effective dose received by a resident in Atomic City at 1.9 mrem per year under Alternative $1 \mathrm{a}$ and estimates the highest potential dose at a publicly accessible location, located at a residence nearest MFC, to be 2.4 mrem per year under Alternative 1a. The federal standard set by 40 CFR 61 , Subpart $\mathrm{H}$, sets the dose limit for public exposure at $10 \mathrm{mrem}$ per year. DOE does not have data on the number and duration of visits made to Middle Butte by Tribal members each year. Using the public dose estimates as best available data, DOE believes the potential effective dose to Tribal members going to Middle Butte would be no higher than the public receptor doses estimated in the draft EA.

6. Depending on the direction from the production facility, radionuclide soil deposition rates from air emissions peak at distances of $100 \mathrm{~m}$ to $300 \mathrm{~m}$ from the facility. As stated in the EA, the highest deposition rates were at approximately $200 \mathrm{~m}$ in the northeast direction, and the potential soil contamination is not likely to result in adverse health impacts under reasonable maximum exposure conditions for long-term chronic exposures. Since long-term exposures are not possible on the INL Site, the actual impacts would be much less. In addition, deposition rates beyond $200 \mathrm{~m}$ decrease rapidly with distance from the facility. The soil concentrations at Middle Butte and anywhere outside the INL Site would be a fraction of the soil concentrations presented in the EA and thus soil impacts are bounded by those presented in the EA. Furthermore, the public doses presented in the EA include direct radiation from soil contamination. Thus, the impacts of soil deposition are included in the impact assessment.

7. The draft EA evaluated radiation exposures to terrestrial plants and animals resulting from the proposed HALEU project. Although the dose to humans was not estimated in the RESRAD-BIOTA calculations, the limiting Biota Concentration Guides (BCGs) are so conservative that the dose to humans resulting from eating contaminated biota at the BCG levels is well below the limit established by DOE for the protection of public health ( $100 \mathrm{mrem} / \mathrm{yr})$. That is, if a person eats $8 \mathrm{oz}(227 \mathrm{~g})$ of meat that is contaminated at the BCG level every day for a year, he or she would not exceed the $100 \mathrm{mrem} / \mathrm{yr} \mathrm{dose} \mathrm{limit.} \mathrm{For} \mathrm{example,} \mathrm{the}$ two highest contributors to biota dose were determined to be strontium-90 (Sr-90) and cesium-137 (Cs-137). The BGCs established for these radionuclides are 3.89 and $1.26 \mathrm{pCi} / \mathrm{gsoil}$, respectively. Using concentration ratios (i.e., concentrationmeat/concentrationsoil) of 17 for Sr-90 and 67 for Cs-137, as provided in RESRAD-Biota documentation, the resulting concentrations in meat of a game animal grazing exclusively in the contaminated area for a year would be 66.13 $\mathrm{pCi} / \mathrm{g}(\mathrm{Sr}-90)$ and $84.42 \mathrm{pCi} / \mathrm{g}$ (Cs-137). Ingestion dose coefficients may be found in the Federal Guidance Report 13 database 


\section{Table A-2. DOE's response to comments on the draft EA sorted by commenter.}

(https://www.epa.gov/radiation/federal-guidance-report-no-13-cancer-risk-coefficients-environmental-exposure). They are 1.02×10-14 mrem/pCiSr-90 and $5.02 \times 10-13 \mathrm{mrem} / \mathrm{pCiCs}-137$. Assuming a person eats $227 \mathrm{~g} /$ day ( 8 ounces) for a year, the total dose received would be $3.57 \times 10-6 \mathrm{mrem} / \mathrm{yr}$, well below the DOE dose limit of $100 \mathrm{mrem} / \mathrm{yr}$. This is conservative because the calculations do not take into effect bioelimination of the radionuclides by the animals during the year and the fact that game animals would visit the project area rarely and for minimal time so the actual doses would be even lower.

8. The cumulative impacts presented in Table 8 of the EA include all potential doses from current operations, reasonably foreseeable actions and the proposed action. Although the doses for each action in the table are not all calculated at the current INL Site maximally exposed individual (MEI) location which is

Frenchman's Cabin, they are conservatively added together as if they all occur at Frenchman's cabin. If the HALEU emissions estimated in the EA were actual emissions, the INL MEl location would likely move from Frenchman's cabin to a location nearer INTEC or MFC depending on the alternative selected. However, the maximum annual dose would not be higher than the maximum dose predicted in the EA (see Table 2 ) plus the annual INL radiological NESHAP dose (0.008 $\mathrm{mrem} / \mathrm{yr}$ in 2017, see Table 8).

Receptors located N, NNE and NE of MFC and INTEC are much farther away than the receptor locations examined in the EA. In addition, doses in this direction at the same distance are less than doses in the S, SSW and SW directions. The predominant wind direction is generally to the NE during the day, but higher speeds and unstable-to-neutral atmospheric conditions result in greater dispersion and dilution. Less dispersion occurs during the nighttime and early morning hours when atmospheric conditions are more stable and wind speeds are slower and typically to the SW. Therefore, doses in the NE direction would be less than those presented in the EA. 
Table A-2. DOE's response to comments on the draft EA sorted by commenter.

\section{Beatrice Brailsford, Nuclear Program Director, Snake River Alliance}

Comment(s): $9-15$

\section{villo \\ SNAKE RIVER \\ ALLIANCE}

November 30, 2018

David Herrin

daho National Laboratory

1955 Fremont Ave., $83415-122$

By email at haleu@id.doe.gov

Re: Draft Environmental Assessment for the use of DOE-owned High Assay Low-Enriched Uranium Stored at INL (DOE/EA-2087)

Dear Mr. Herrin:

The Snake River Alliance is Idaho's grassroots nuclear watchdog and clean energy advocate. We were founded in 1979. I submit these comments on behalf of our dues-paying members.

Public participation is at the core of the National Environmental Policy Act. I thank haleu@id.doe.gov for help with the Department of Energy's NEPA web page. The advice was valuable, though I continue to think the recent changes to the DOE's web sites have decreased transparency and made it more difficult to find information that has always been intentionally accessible.

Nuclear power is in decline. Efforts to slow that decline nearly always have a tinge of magical thinking about hem. "Build it and they will come." The project to use DOE-owned high-assay low enriched uraniun HALEU) stored at the Idaho National Laboratory is an example.

This project does not have a real life purpose or need. The third sentence of the draft environmental assessment reads: "Private sector advanced ntelear reactor designs and advanced nuclear fuel designs call for use of "HALEU, but currently no commercial facility manufactures HALEU." Furthermore, it even asserts there are no HALEU reactors. The DOE must not create a "need" for HALEU reactors by creating HALEU fuel. A new draft EA must list and discuss the private sector designs it alludes to, including what entities are pursuing them how close to deployment they are, and why the US government rather than the commercial nuclear industry would be fueling them

Please support the assertion that "other applications using HALEU may be of interest to the commercial industry" (2). Please describe the "research and development activities" and "industry applications" (3) requiring HALEU

BOX 1731 | BOISE, ID 83701 | 208.344.9161

$$
\text { BOX } 425 \text { | POCATELLO, ID } 83204
$$$$
208.233 .7212
$$

What is the expected duration of this project? Right now, INL proposes using 10 tons of already available HALEU. The total annual throughput could be half this, so the initial proposed feedstock would be gone in two years. What is the total stockpile of HALEU produced by pyroprocessing so far? What has INL's annual production rate been? How much will pyroprocessing produce in the future? (The Treatment and Manageme production rates are so different from reality.)

The project will need far more depleted uranium to lower/adjust the enrichment of the available HALEU. How much DU do you project needing? Does INL already have a stockpile of "clean" depleted uranium that would meet that need? If not, where would it come from? Is using Fermi blanket fuel contemplated? The range of all impacts of supplying depleted uranium must be addressed in the revised EA. 11 Are the environmental impacts of producing ceramic fuels different from those for metallic fuel? Understan traditional-sized reactors, small modular reactors, research reactors, or bench-scale research? Will any of the fuel be used by Battelle Energy Alliance or other entities in Idaho? For what purpose?

It is incorrect to imply that non-defense transuranic waste will be disposed of in the Waste Isolation Pilot Plant WIPP's only mission is to dispose of defense transuranic waste.

The "Reasonably Foreseeable Future Action" list must be explained and amended. Start with the phrase "reasonably foreseeable." Which of these projects have final NEPA Records of Decision (date)? Which have been authorized by Congress (date)? Which are currently receiving appropriated funding? Which are under construction? Which are operating?

Projects under the Idaho Cleanup Project that contribute to the estimated dose must be included in the "Reasonably Foreseeable Future Action" list. After all, the EA's list should address the INL Site as a whole - a single piece of land, a single body of water, a single airshed.

Page 2 of this draft EA states: "The primary mission of the DOE Office of Nuclear Energy is to advance nuclear power as a resource capable of meeting the Nation's energy, environmental, and national security needs by

15 resolving technical, cost, safety, security barriers, and pro and demonstration." Please include information about how the use of DOE-owned HALEU helps resolve each of the concerns flagged in that statement.

I wrote above about the magical thinking that has supported nuclear power in the past. Trying to build ne considerable talents of the INL workforce.

I look forward to reviewing an environmental assessment that responds to these concerns.

Respectfully submitted,

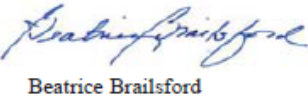

Beatrice Brailsford

Nuclear program director

WWW.SNAKERIVERALLLANCE.ORG

Response(s) 9 - 15: Ms. Brailsford, thank you for your comments. Please refer to the numbered comments and corresponding numbered responses. 
Table A-2. DOE's response to comments on the draft EA sorted by commenter.

9. The U.S. nuclear industry has been working on advanced reactors (including micro-reactors) for the over a decade. Numerous companies/vendors contacted the Department of Energy and Idaho National Laboratory to obtain advice and technical assistance/support in developing advanced reactor designs. One issue that has been identified by vendors is the availability of HALEU fuel. As with any new technology, the supply chain would only become available after a demonstration of the new technology and concept. Some of the advanced reactors vendors requiring HALEU have been in discussion with NRC concerning licensing and operations of these new designs. In addition, the National Defense Authorization Bill section 327 instructed the Department to work with commercial vendors to demonstrate a micro-reactor.

10. As discussed in this EA, the proposed action would make $10 \mathrm{MT}$ of HALEU feedstock produced through the electrometallurgical treatment (EMT) process, and other small quantities of HALEU feedstock stored at INL, available to support early-stage demonstration by the commercial nuclear industry and government agencies. The ongoing EMT process converts sodium-bonded spent nuclear fuel into waste forms suitable for disposal as high-level waste and a HALEU product that is unsuitable for diversion to nuclear weapons, but could be either reused in fuel or disposed of as waste. The 10 MT HALEU feedstock proposed for use in the production of HALEU fuel is largely the result of processing EBR-II driver fuel. EMT of the EBR-II driver fuel, including down blending with depleted uranium, is addressed by DOE's sodium-bonded EIS (DOE/EIS-306, 2000) and is not part of this NEPA action.

This EA conservatively assumes that a total of 5,000 kg HALEU would be processed annually. Approximately 4 MT HALEU feedstock is available from historical and ongoing EMT processing of EBR-II driver fuel. HALEU fuel fabrication would be limited by the EMT processing rate. INL produces about 0.3 MT HALEU annually through the EMT process, with planning underway to potentially increase the production rate to meet programmatic needs. The conservative assumptions of an annual HALEU fuel production of up to $5 \mathrm{MTHM} / \mathrm{yr}$ used in the EA provides a conservative estimation of annual airborne releases and potential accidents.

11. From a practical standpoint, the environmental impacts are expected to be essentially the same for producing either metallic or ceramic fuel. For purposes of determining impacts for the EA, production of ceramic fuel results in higher releases for some radionuclides and thus results in greater impacts. This is because the prescribed methodology for determining emissions is based on temperature and the process to create ceramic fuel would involve heating the material to a higher temperature. If the temperature exceeds the melting point or boiling point of a specific radionuclide, the estimated emission rate for that radionuclide increases. Thus for the EA, calculated emissions were based on the highest temperature expected. Practically speaking, radionuclides that become liquids or gases during the heating process would likely be converted back to a solid before reaching the HEPA filters, and thus the emissions would be less than those assumed in the EA.

12. Approximately $10 \mathrm{MT}$ of HALEU fuel at a U-235 enrichment level of $19.75 \%$ is anticipated to be produced as part of the proposed action. DOE has made no decision on the specific use of the fuel. The fuel could be used in advanced reactor design or for the purpose of research and development. DOE will work with other Federal agencies and commercial vendors to determine use of HALEU fuel. Any reactors that use the HALEU fuel addressed in this EA will require their own NEPA review which would include disposition of spent nuclear fuel and other waste.

13. In its management of radioactive waste, DOE follows applicable radioactive waste management statutes, including the Land Withdrawal Act. For purposes of this analysis, it is assumed that the majority of materials comes from the processing of EBR-II spent fuel. EBR-II missions involved defense-related activities. Therefore, the transuranic (TRU) waste generated from production of HALEU fuel would be defense-related and can be disposed at the Waste Isolation Pilot Plant (WIPP).TRU waste that is sent to the Waste Isolation Pilot Plant (WIPP) must meet rigorous Waste Acceptance Criteria, which includes among other things a defense waste determination. DOE takes actions that are practical to segregate and keep separate defense origin material from non-defense origin material. However, due to the potential for cross contamination, DOE cannot eliminate the generation and transportation of TRU wastes to WIPP from consideration in the EA. Clarification on the defense-related origin of the HALEU fuel was added to Section 4.1.2.2 (page 19). 


\section{Table A-2. DOE's response to comments on the draft EA sorted by commenter.}

14. Consistent with information given in recent EAs, cumulative impacts presented in Table 8 of the EA include all potential doses from current operations (including Idaho Cleanup Project operations), reasonably foreseeable actions and the proposed action. RH-LLW facility and TREAT are operating, the naval reactors facility recapitalization is under construction, and we removed the 'DOE Idaho Spent Fuel Facility (NRC 2004) from the table because the project is unlikely to happen. The other projects are expected in the future. We updated the references in Table 8 and Section 7 of the EA.

15. The proposed actions fits within DOE's mission to advance nuclear power. Consistent with DOE's mission, Congress directed the Department to work with commercial vendors to demonstrate a micro-reactor as described in The National Defense Authorization Bill Section 327.

SEC. 327. REPORT ON PILOT PROGRAM FOR MICRO-REACTORS.

(a) Report Required.-Not later than 12 months after the date of enactment of this Act, the Secretary shall develop and submit to the Committee on Armed Services and the Committee on Energy and Commerce in the House of Representatives and the Committee on Armed Services and the Committee on Energy and Natural Resources in the Senate a report describing the requirements for, and components of, a pilot program to provide resilience for critical national security infrastructure at Department of Defense facilities with high energy intensity and currently expensive utility rates and Department of Energy facilities by contracting with a commercial entity to site, construct, and operate at least one licensed micro-reactor at a facility identified under the report by December 31, 2027. 
Table A-2. DOE's response to comments on the draft EA sorted by commenter.

\section{Chuck Broscious, President, Environmental Defense Institute}

\section{Comment(s): 16 - 24}

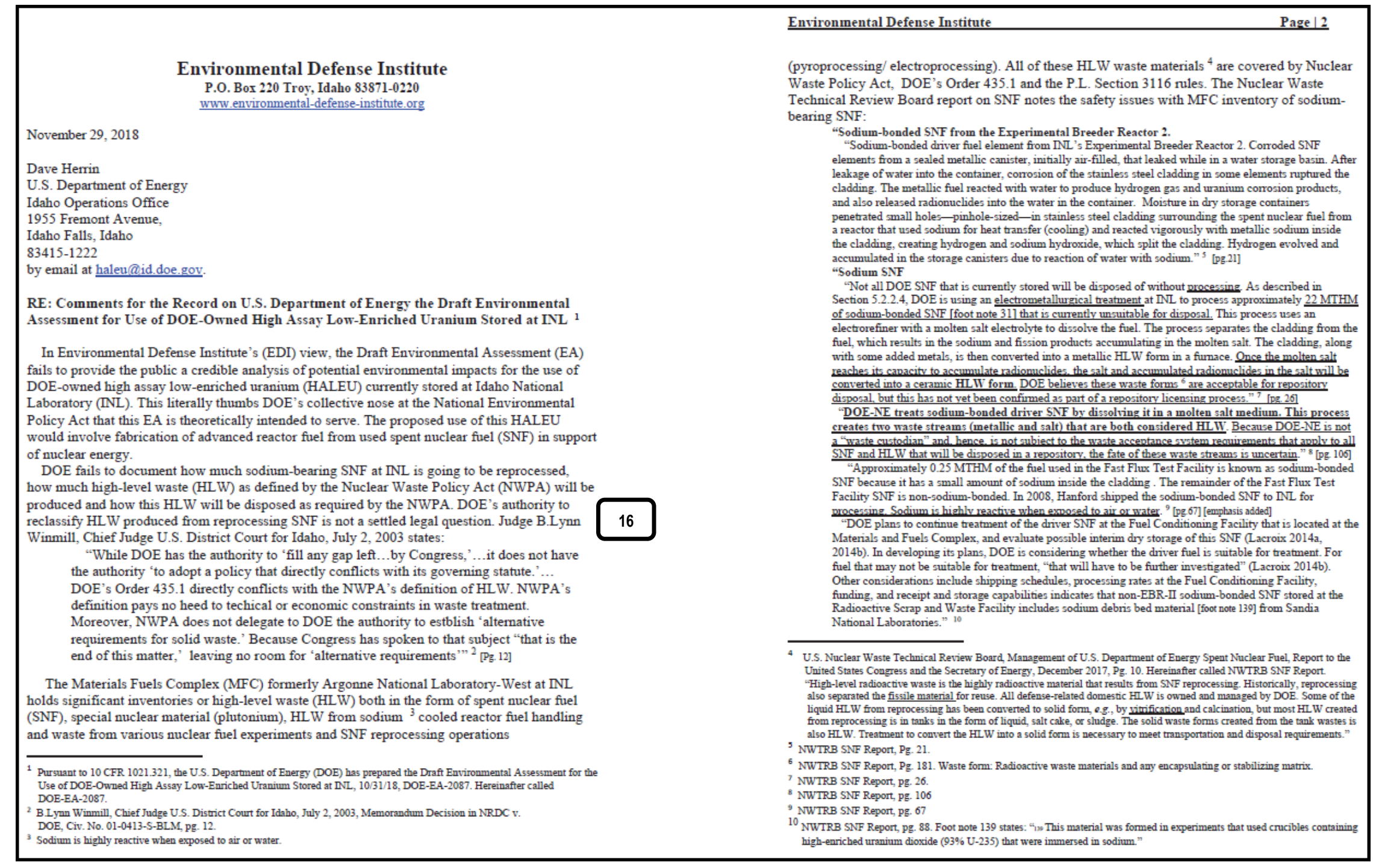


Table A-2. DOE's response to comments on the draft EA sorted by commenter.

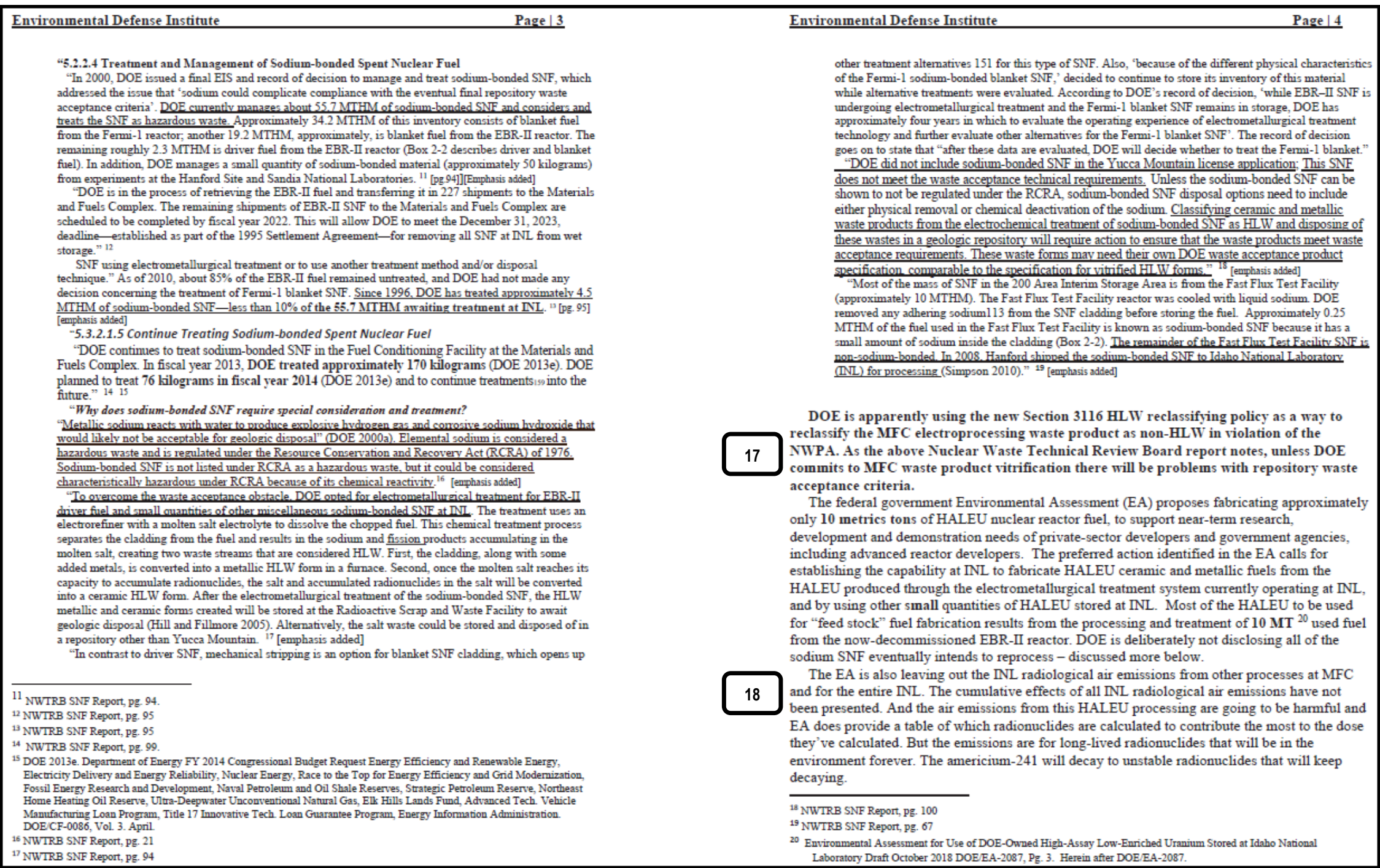


Table A-2. DOE's response to comments on the draft EA sorted by commenter.

DOE announces the $2,000^{\circ} \mathrm{C}$ electrometallurgical treatment ${ }^{21}$ of SNF High-Assay LowEnriched Uranium. ${ }^{2}$ DOE's HALU EA "Radiological Impacts of Atmospheric Releases" only uses one of the two MFC reprocessing facilities $(2,500 \mathrm{~kg}$ of HULU feedstock) to estimate the

$2,500 \mathrm{~kg}$ annually for a total of $5,000 \mathrm{~kg}$ processes at MFC." 23 This is intentionally deceptive by only showing $1 / 2$ of production emissions. Also the EA does not offer the total emissions for reprocessing all of the 10 MT SNF let alone the rest of the sodium SN.

DOE's deception extends to the total amount of sodium-bonded fuel slated for reprocessing at MFC. "Since 1996, DOE has treated approximately 4.5 MTHM of sodiumbonded SNF-less than $10 \%$ of the 55.7 MTHM awaiting treatment at INL." ${ }^{24}$

DOE's EA "Waste Management" only reports $218 \mathrm{~m}^{3}$ attributable to MFC but states: During FY-2018, INL sent $934 \mathrm{~m}^{3}$ low-level waste (LLW) to off-site facilities for disposal. INL would accumulate and store any waste generated per Federal and state regulations, and if Regardless what DOE wants to classify the MFC SNF reprocessing waste as - it still is LW as defined by the NWPA and must be disposed in a deep geologic repository. $D O E$ is pushing this nuclear fuel program when there is no market for new reactors ${ }^{27}$ and most mportantly nowhere to put the SNF and high-level waste generated by the HALEU processing nor the SNF after use in current reactors. The Nuclear Waste Technical Review Board report on SNF as it relates to limited HLW disposal options notes: The MFC activated metals [waste] will be $\mathrm{KH} L L \mathrm{~W}$ in that package contact dose is expected to routinety excest metal wiould be chansis aded]

The EA is leaving out the complete disposal accounting of MFC Sodium-bonded SNF and HLW Produced by HALEU Reprocessing. As previous noted, "DOE continues to treat sodium-bonded SNF in the Fuel Conditioning Facility at the Materials and Fuels Complex. In 76 kilograms in fiscal year 2014 (DOE 2013e) and to continue treatments into the future." 23

DOE/EA-2087, Pg.13.

DOEEA-2087

DOEEA-2087, Pg.14.

DOEEA-2087, Pg.12.

NWTRB SNF Report, pg. 81. "The approximately 56 MTHM of sodium-bonded SNF in [Figure 5-3] Group 31 will be

Dan Pope, A Nortivest distaste for mclear power, Origivally published Seartle Times, July 31,2008 , Updated July $31,2008$. NN/EXT-06-11601 Rev. 1, pg. B-2

Defort, pg. 99. Metric ton $=1,000 \mathrm{~g}=$ kilograms; This is different (includes total wt. (fuel + cladding) than a metric ton Leary metal (includes uraniumplplutonium

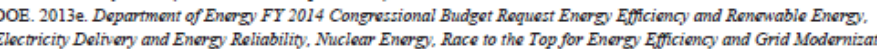

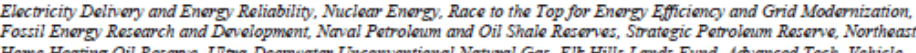

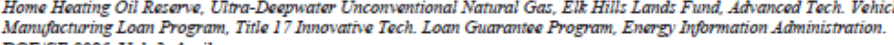
DOE/CF-0086, Vol. 3. Apri.
Environmental Defense Institute

Sodium-bonded fuel at INL Tabl

\begin{tabular}{|l|l|l|}
\hline INL Storage Site & Used Fuel Type & $\begin{array}{l}\text { Quantity in } \\
\text { MTHM * }\end{array}$ \\
\hline Materials and Fuels Complex (MFC) & & \\
Radioactive Scrap and Waste & EBR-II driver fuel & 2.30 \\
Facility (RSWF) & EBR-II blanket fuel & 19.20 \\
& Han. FFTF driver & 10.00 \\
Hot Fuel Examination Facility & Han. FFTF driver & 0.01 \\
\hline Idaho Nuclear Engineering and & & \\
Technology Center (INTEC) & & \\
(only the sodium bearing fuel) & & \\
CPP-666 (wet) & EBR-II driver fuel & 2.00 \\
CPP-749 (dry) & Fermi-1 & 34.20 \\
\hline & Totals & s7.71** \\
\hline
\end{tabular}

Source: Management of U.S. Department of Energy Spent Nuclear Fuel, December 2017, U.S, Pg. 94.

; this understates the weight of the fref hat includes cladding and antached parts - DOE does not offer a clear inventory of sodium SNF in the EA or in other publicly available reports; so this total is an
estimate based on what EDI has found to date. Also the above table does not include the 170 kilograms treated in 2013 and 76 kilograms treated in 201

An example of the uncertainty of the quantity of sodium-bonded SNF at INL that will require reprocessing and will produce high-level waste $(\mathrm{HL} W)$ the Fast Flux Test Facility below 10 MTHM is included in the above table. As previously cited

"Most of the mass of SNF in the 200 Area Interim Storage Area is from the Fast Flux Test Facility The Fast Flux Test Facility reactor was cooled with liquid sodium DOE MTHM of the fuel used in the Fast Flux Test Facility is known as sodium-bonded SNF because it has a small amount of sodium inside the cladding (Box 2-2). The remainder of the Fast Flux Test Facility SNF non-sodium-bonded. In 2008 , Hanford

Materials and Fuels Complex has treated roughly 4.5 MTHM of sodium-bonded SNF (driver fuel) since 1996. The two waste forms are Ceramic and Metal Waste HLW forms stored at the MFC's RSWF.

Activated metals produced during MFC SNF reprocessing

"The Matenals and Fuels Complex (MFC) will generate activated metals during waste segregation operations in the planned Remote Treatment Project (RTP) [now called the Remote-Handled Waste
Disposal Facility]. LIW Stored at MFC concists has been drained of sodium and fuel removed. The hardware is typically stainless steel. LLW is stored in number of configurations including pre-1978 waste cans, and in the post 1978, HFEF 5-Cask waste cans.

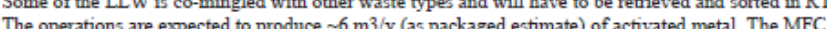
activated metals will be RH LLW in that package contact dose is expected to routhely exceed $200 \mathrm{mR}$. and like the NRF and ATR activated metals could reach 30,000 R/hr. The MFC activated metal would be classified under 10 CFR 61 typically as Class B and C with about $50 \%$ exceeding Class C. No specific activity inforition is included The RTP is expected to operate FY 2012 through 2035 ." "IO 
Table A-2. DOE's response to comments on the draft EA sorted by commenter.

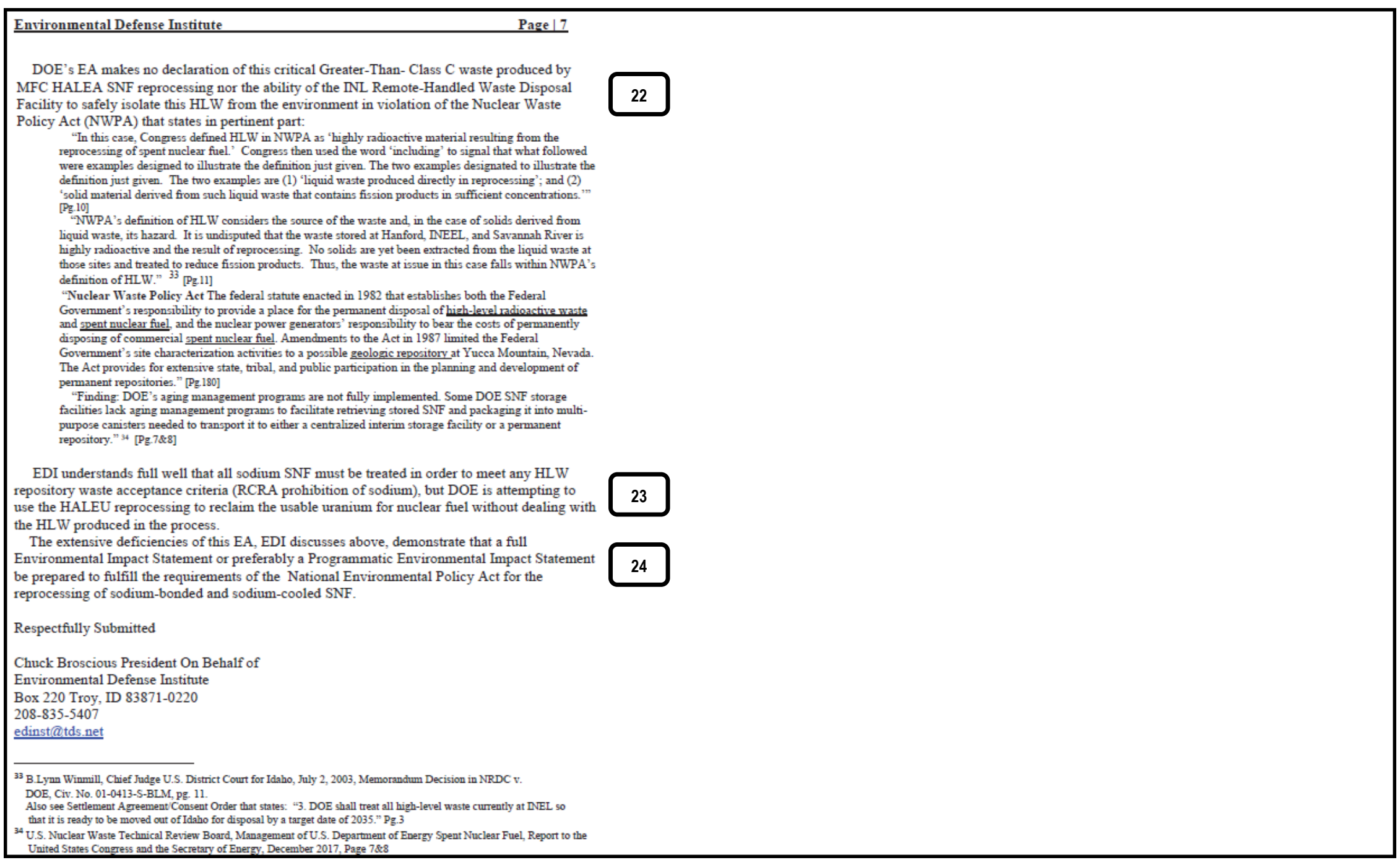

Response(s) 16 - 24: Mr. Broscious, thank you for your comments. Please refer to the numbered comments and corresponding numbered responses.

16. The proposed action in this EA is to use uranium product material resulting from the EMT process. Information regarding sodium-bonded spent nuclear fuel and the waste generated from the EMT process was addressed in the Final Environmental Impact Statement for the Treatment and Management of Sodium-Bonded Spent Nuclear Fuel (DOE/EIS-0306).

17. DOE is not reclassifying electro processing waste as non-high-level waste. The Final Environmental Impact Statement for the Treatment and Management of Sodium-Bonded Spent Nuclear Fuel (DOE/EIS-0306, 2000) addresses the wastes and products from the EMT process. The wastes would be dispositioned as 
Table A-2. DOE's response to comments on the draft EA sorted by commenter.

addressed in the EIS. The ROD did not make a decision on the disposition or use of the HALEU product from the EMT process. This EA addresses the use of HALEU product.

18. Table 8 of the EA presents the cumulative impact of current INL emissions and emissions from reasonably foreseeable actions, including production of HALEU fuel. The maximum cumulative impact is less than the $10 \mathrm{mrem} / \mathrm{yr}$ regulatory limit from $40 \mathrm{CFR} 61$, Subpart $\mathrm{H}$. Although the doses for each action in Table 8 are not all calculated at the current INL Site maximally exposed individual (MEI) location, Frenchman's Cabin, they are conservatively added together as if they all occur at Frenchman's cabin. If the HALEU emissions estimated in the EA were actual emissions, the INL MEl location would likely move from Frenchman's cabin to a location nearer INTEC or MFC depending on the alternative selected. However, the maximum annual dose would not be higher than the maximum dose predicted in the EA (depends on the alternative, see Table 2) plus the annual INL radiological NESHAP dose $(0.008 \mathrm{mrem} / \mathrm{yr}$ in 2017 , see Table 8). Finally, the dose calculations presented in the EA are compliant with 40 CFR 61, Subpart H (NESHAP) requirements. This regulation requires the model used to predict dose use a 100-year period for emission, deposition and build-up of radionuclides in soil. Because the facility is expected to operate only a few years, the 100-yr build up time is very conservative and presumes all emissions would occur for a considerably longer time.

19. Table 1 presents the inventory in $2,500 \mathrm{~kg}$ of feedstock material, the maximum amount that could be processed at a single facility in one year. The footnote in Table 1 explains that Alternative 1a would process 2,500 kg at two separate facilities at MFC for a total of 5,000 $\mathrm{kg}$ processed at MFC, and Alternative $1 \mathrm{~b}$ would process $2,500 \mathrm{~kg}$ each at a facility at INTEC and a facility at MFC. The EA is based on use of $10 \mathrm{MT}$ of HALEU feedstock at $19.75 \%$ U-235 enrichment to produce HALEU fuel. By processing $5,000 \mathrm{~kg} / \mathrm{yr}$, it would require only 2 years to produce the HALEU fuel. If the production rate is less than 5,000 $\mathrm{kg} / \mathrm{yr}$, the material processed each year would be less than analyzed in the EA and the annual impacts would be less.

20. See response to comment \#17.

21. The proposed action in this EA is not reprocessing. The proposed action is using a non-waste product from the EMT process to produce nuclear fuel, as described in Section 1.1 of this EA. See also the response to comment \#17.

22. HALEU feedstock is obtained from electrometallurgical treatment of Experimental Breeder Reactor-II (EBR-II) fuel with the intended U-235 enrichment, contaminated with about $100 \mathrm{ppm}$ transuranic contaminants. Residual fission products have been removed such that the feedstock can be handled without extensive shielding (i.e., without requiring shielding walls as in hot cells, although containment of low-activity contamination would require gloveboxes). Based on the starting point (HALEU feedstock) in the production of HALEU fuel, this HALEU process by definition would not generate Greater-Than-Class $C$ waste nor would it generate High Level Waste. DOE clarified this in Section 4.1.2.2 'Waste Generation and Management'. See also response to comment \#21.

\section{See response to comment \#17}

24. In accordance with the NEPA implementing regulations, a federal agency can prepare an EA at any time for a proposed action. If potential significant environmental impacts are identified, an environmental impact statement (EIS) can always be pursued. Conversely, if no significant environmental impacts are identified, the EA is the appropriate level of documentation and no further evaluation is necessary. DOE ensures the level and quality of analysis and data compiled for the EA is suitable for use in an EIS if it is decided that an EIS should be prepared. This course of action is appropriate for use when an agency has a basis for the belief that the proposal will not manifest significant environmental impacts. 
Table A-2. DOE's response to comments on the draft EA sorted by commenter.

\section{Jason Charles, Self}

Comment(s): 25

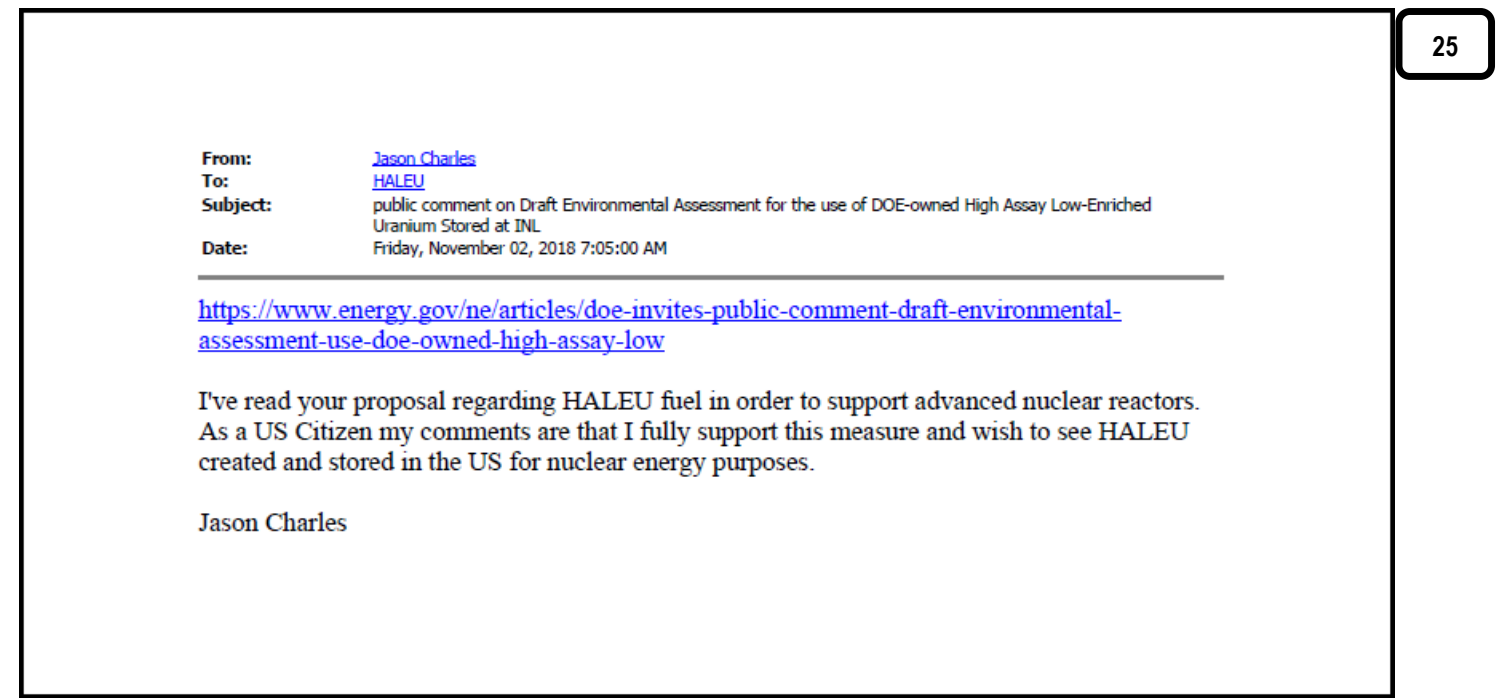

Response(s) 25: Mr. Charles, DOE acknowledges your comment supporting the proposed action. Thank you.

\section{Benjamin Cox, Self}

Comment(s): 26

From: Benjamin Cox<auscult@gmail.com>

Sent: Wednesday, November 28, 2018 6:14 AM

To: HALEU <haleu@id.doe.gov>

Subject: HALEU Environmental Assessment

Mr. Herrin,

I highly support the creation of HALEU for use in testing Advanced Fuel Types at INL. Further I encourage a first testing of Lightbridge Metallic Fuel in 2019 at INL.

$\mathrm{V} / \mathrm{R}$,

Benjamin Cox

703-835-7776

(2)

Response(s) 26: Mr. Cox, DOE acknowledges your comment supporting the proposed action. Thank you. 
Table A-2. DOE's response to comments on the draft EA sorted by commenter.

\section{Suketu Gandi, Self}

\section{Comment(s): 27 and 28}

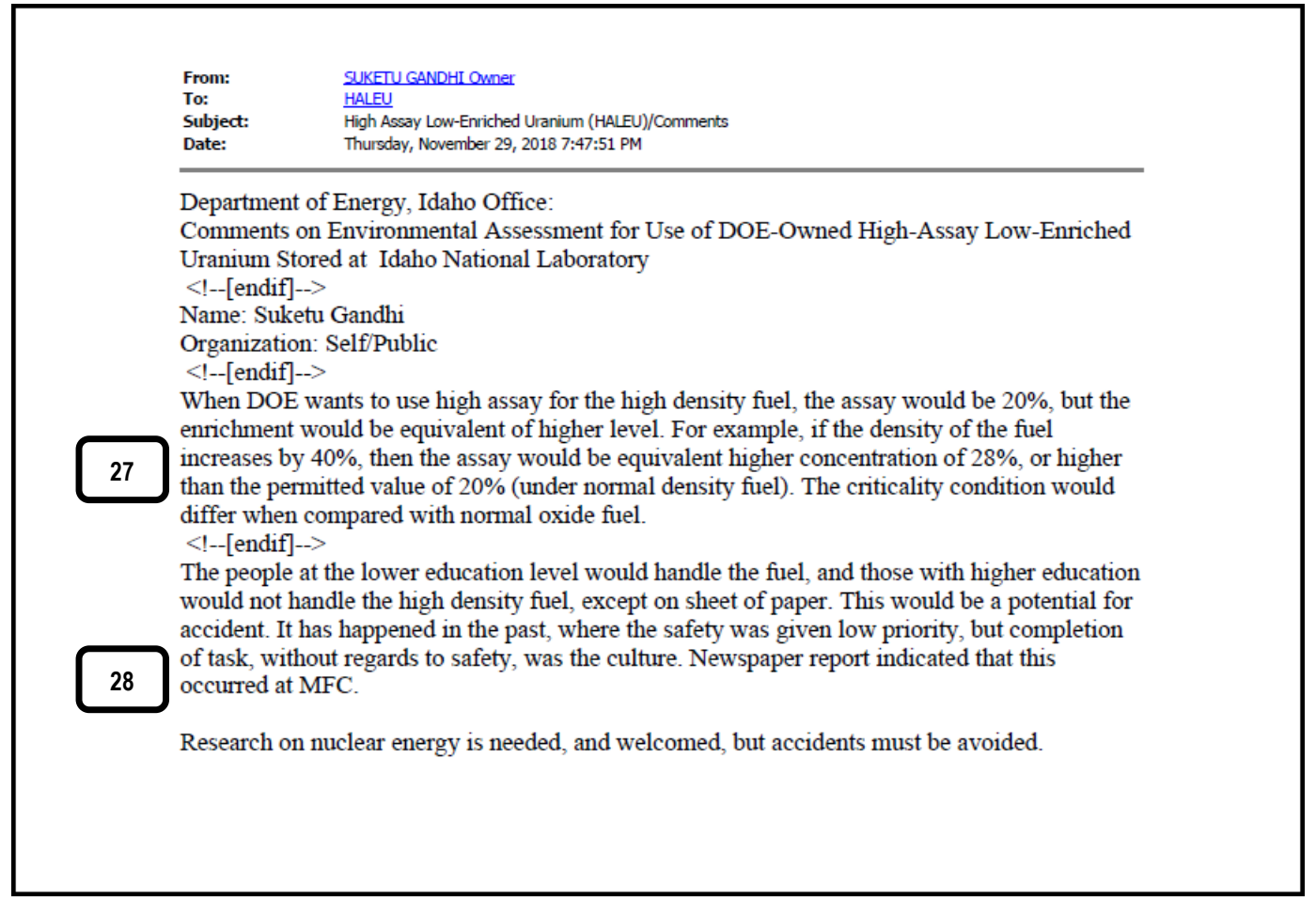

Response(s) 27 and 28: Mr. Gandi, thank you for your comments. Please refer to the numbered comments and corresponding numbered responses.

27. In criticality safety assessments, the uranium enrichment and material/fuel density are considered explicitly and independently of each other. Therefore, derivation of an effective uranium enrichment based on uranium density is not necessary. As discussed in the EA, engineered and administrative controls would be incorporated into the facility and process operations to prevent and mitigate worker risk associated with a criticality. Derivation of these controls would be informed directly from a criticality safety assessment for the process.

28. Worker and public safety are INL's highest priority and INL workers are highly trained in performing their jobs. Education and training requirements are commensurate with job functions. 
Table A-2. DOE's response to comments on the draft EA sorted by commenter.

Peter Hastings, Vice President, Kairos Power

Comment(s): 29

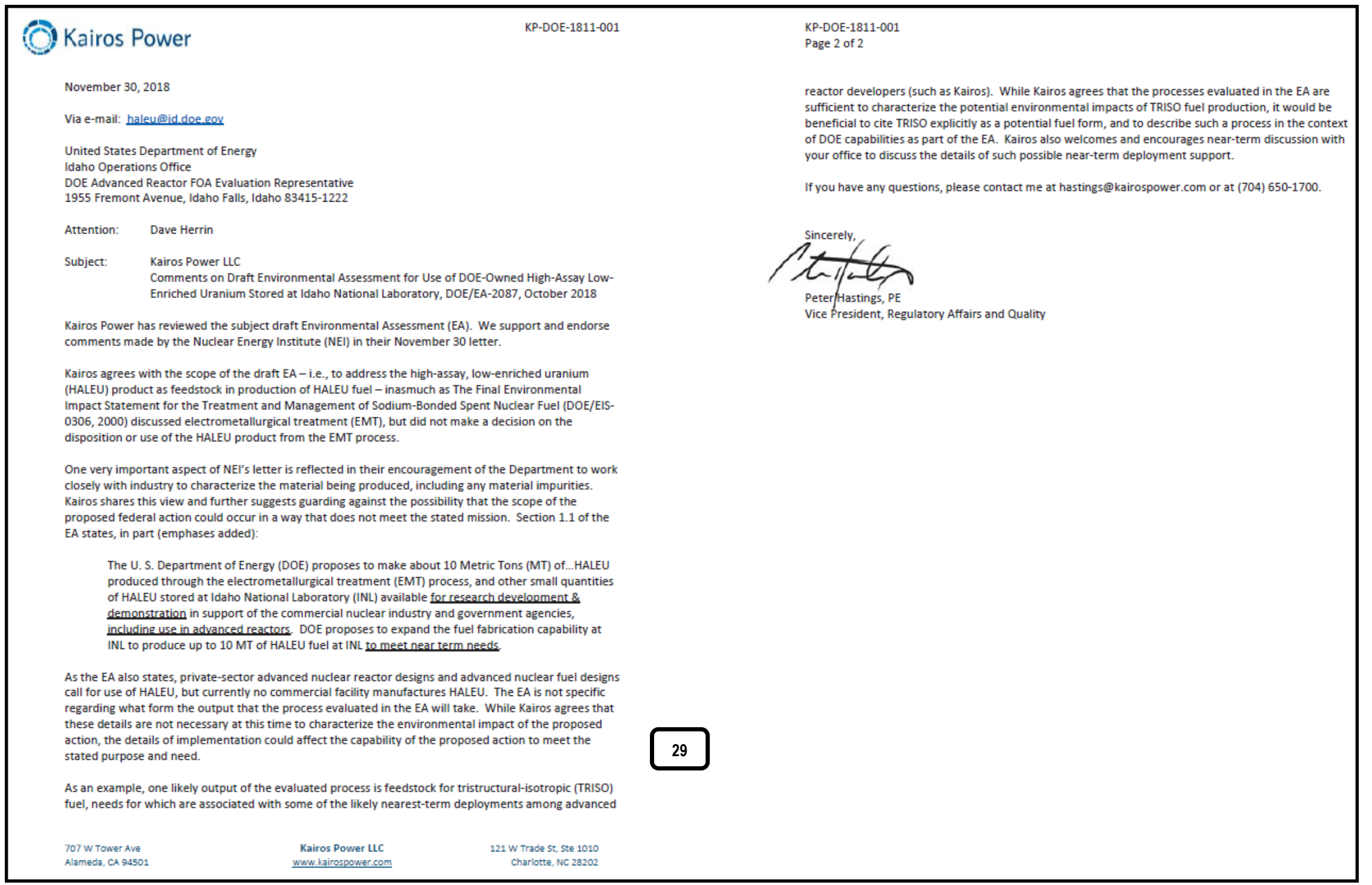

Response(s) 29: Mr. Hastings, thank you for your comments. Please refer to the numbered comments and corresponding numbered responses. 
Table A-2. DOE's response to comments on the draft EA sorted by commenter.

29. In scoping of the proposed action, DOE assumed that developers of TRISO fuel concepts would not be able to use HALEU resulting from the EMT of EBR-II driver fuel due to the presence of TRU contaminants and residual fission products that would require handling in gloveboxes. If ongoing efforts to decrease residual fission product contamination of the HALEU feedstock being conducted as part of the EMT process are successful, additional uses of the FCF HALEU product for other fuel types may be considered. Such consideration would be subject to appropriate evaluation in accordance with NEPA.

\section{Lars Jorgensen, CEO, ThorCon US}

\section{Comment(s): 30 and 31}

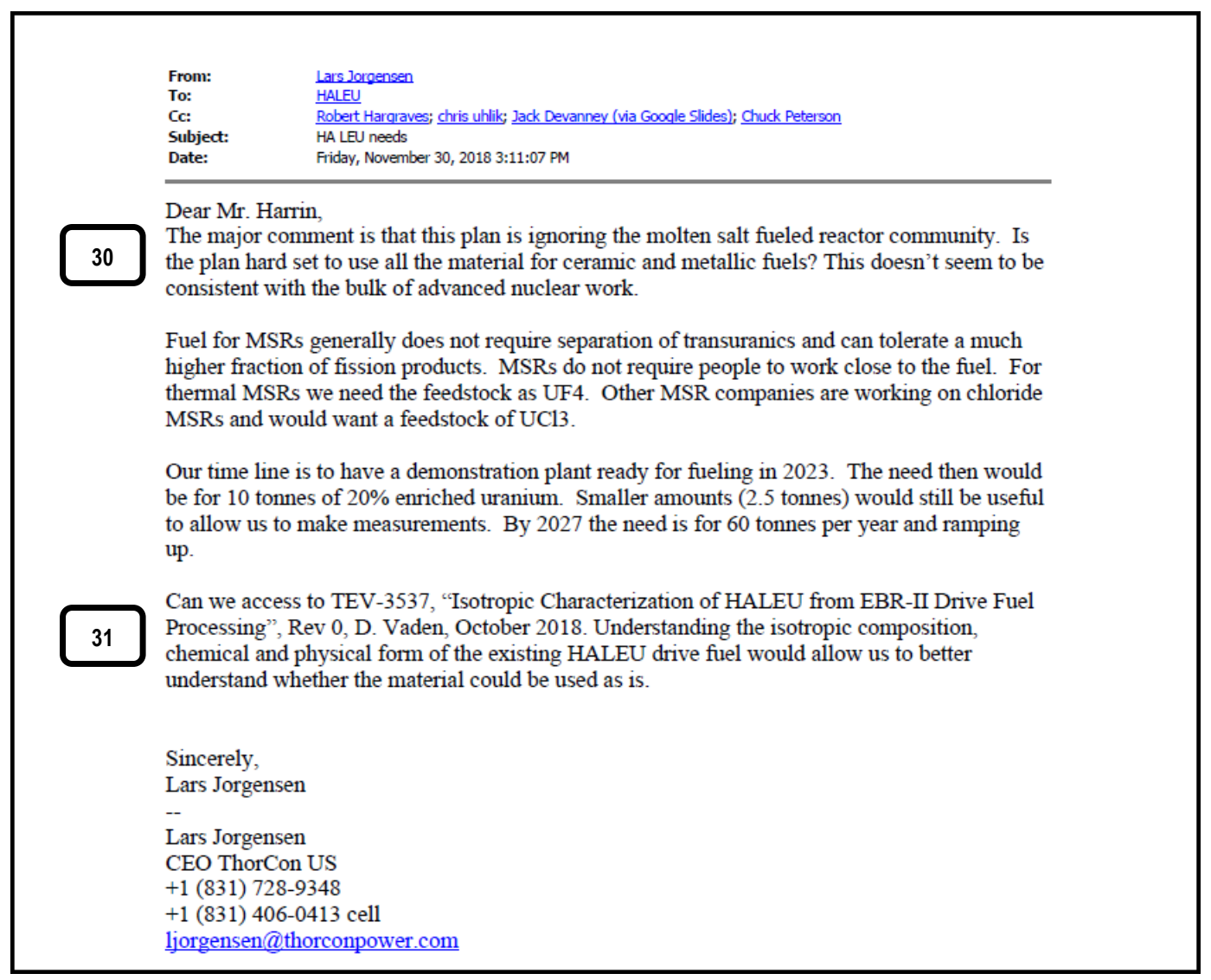

Response(s) 30 and 31: Mr. Jorgensen, thank you for your comments. Please refer to the numbered comments and corresponding numbered responses.

30. In scoping of the proposed action, DOE assumed that developers of molten salt reactor (MSR) concepts would not be able to use HALEU resulting from the EMT of EBR-II driver fuel due to the presence of residual fission products. If ongoing efforts to decrease TRU contaminants and residual fission product 
Table A-2. DOE's response to comments on the draft EA sorted by commenter.

contamination of the HALEU feedstock being conducted as part of the EMT process are successful, additional uses of the FCF HALEU product for other fuel types may be considered. Such consideration would be subject to appropriate evaluation in accordance with NEPA.

31. Sent copy of TEV-3537 'Isotopic Characterization of HALEU from EBR-II Driver Fuel Processing”. 
Table A-2. DOE's response to comments on the draft EA sorted by commenter.

\section{Edwin Lyman, Senior Scientist, Union of Concerned Scientists}

Comment(s) 32: Mr. Lyman, thank you for your comments. Please refer to the numbered comments and corresponding numbered responses.

November 30,2018

Dave Herrin

U.S. Department of Energy

Idaho Operations Office

1955 Fremont Avenue

Idaho Falls, ID 83415

Comment on the Draft Environmental Assessment for the Use of DOE-Owned High Assay LowEnriched Uranium Stored at INL. DOE/EA-2087

The draft EA is deficient because it does not evaluate the potential need for, and environmental impacts of, an aqueous processing capability for purification of HALEU feedstock. On page 4 ,

the draft EA states that it assumes that the HALEU produced from fuel processing (e.g.

pyroprocessing) is contaminated with $100 \mathrm{ppm}$ transuranics. It is well-known that this HALEU

feedstock has significant plutonium contamination, and therefore is not suitable for further

downblending for use in LWRs, because of the problems that INL has experienced with the pyroprocessing process.

The draft EA does not discuss the feedstock specifications for the various advanced reactor types for which it proposes developing fuel fabrication capabilities. While fast reactors may be able to
tolerate some level of transuranic contamination, thermal gas-cooled, molten salt, and light-water

reactors cannot. Thus unless INL's intent is to only provide HALEU feedstock for fast reactors,

which is not stated in the draft EA, it likely will need to install aqueous processing lines to remove the transuranics. Such processes would generate liquid transuranic wastes requiring storage and disposition, as well as additional atmospheric releases. The processes would also introduce new radiological risks and chemical hazards that require analysis.

By failing to consider the impacts of aqueous processing in the draft EA, even though it is obvious that it could be necessary and therefore would be a connected action, DOE may be committing unlawful segmentation.

Therefore, the EA should consider two different processing alternatives: one in which HALEU fuel is fabricated only for reactors that can use fuel with transuranic contamination, and one in which HALEU fuel is fabricated for reactors that require purified feed.

Sincerely,

Edwin Lyman

Senior Scientist, Global Security Program and Acting Director, Nuclear Safety Project

Union of Concerned Scientists

$1825 \mathrm{~K} \mathrm{St}$, NW Ste. 800

Washington, DC 20006 
Table A-2. DOE's response to comments on the draft EA sorted by commenter.

Response(s) 32: Please refer to the numbered comments and corresponding numbered responses.

32. The commenter is correct that the expected contaminants in the FCF HALEU product would likely render the material unsuitable for use in thermalspectrum reactors, though suitable for fast-spectrum reactors. The scope addressed by the EA purposely excludes further decontamination using aqueous methods, primarily to limit cost. So, fuel made from the material would be limited to use in fast-spectrum reactors, or other reactor systems in which the reactor performance and fuel performance are not sensitive to those contaminants. Should the Department decide later to include potential application to thermal-spectrum reactors, such consideration would be subject to appropriate evaluation in accordance with NEPA.

\section{Bob McGarn, Self}

Comment(s): 33

\begin{tabular}{|c|c|}
\hline $\begin{array}{l}\text { From: } \\
\text { To: } \\
\text { Subjet: } \\
\text { Date: }\end{array}$ & 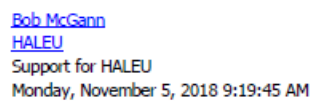 \\
\hline
\end{tabular}

To Whom It May Concern:

I would like to lend my support to the DOE in its drive to allow HALEU to be made available for research purposes.

The future of the US nuclear fleet in the face of cheaper alternatives such as natural gas and solar is a dire threat to our nation's ability to keep that fleet up and running. The increased economics that are available with some of the HALEU fuel designs have the ability to move the fleet to a more productive and profitable position. The move to HALEU has the ability to push the fleet's profitability forward with immediate and meaningful impact via power uprates.

Beyond the drive to profitability using power uprates from new HALEU fuel designs, our nation security goals must include a cutting-edge nuclear fleet rather than a stagnated fleet as compared to the advanced designs being rolled-out globally. Additionally, the benefits globally of reducing our $\mathrm{CO} 2$ emissions, as well as the proliferation-resistant nature of some fuel designs incorporating HALEU, mandate that the US must push forward with every means necessary to make HALEU available for research with the goal of licensing future fuel designs.

Kind regards,

Robert V. McGann

444 E. 84th Street, \#7F

New York, NY 10028

(917) 664-4955

Response(s) 33: DOE acknowledges your comment supporting the proposed action. Thank you. 
Table A-2. DOE's response to comments on the draft EA sorted by commenter.

Rich Powell, Executive Director, ClearPath and David Blee, President and CEO, U.S. Nuclear Industry Council

Comment(s): 34

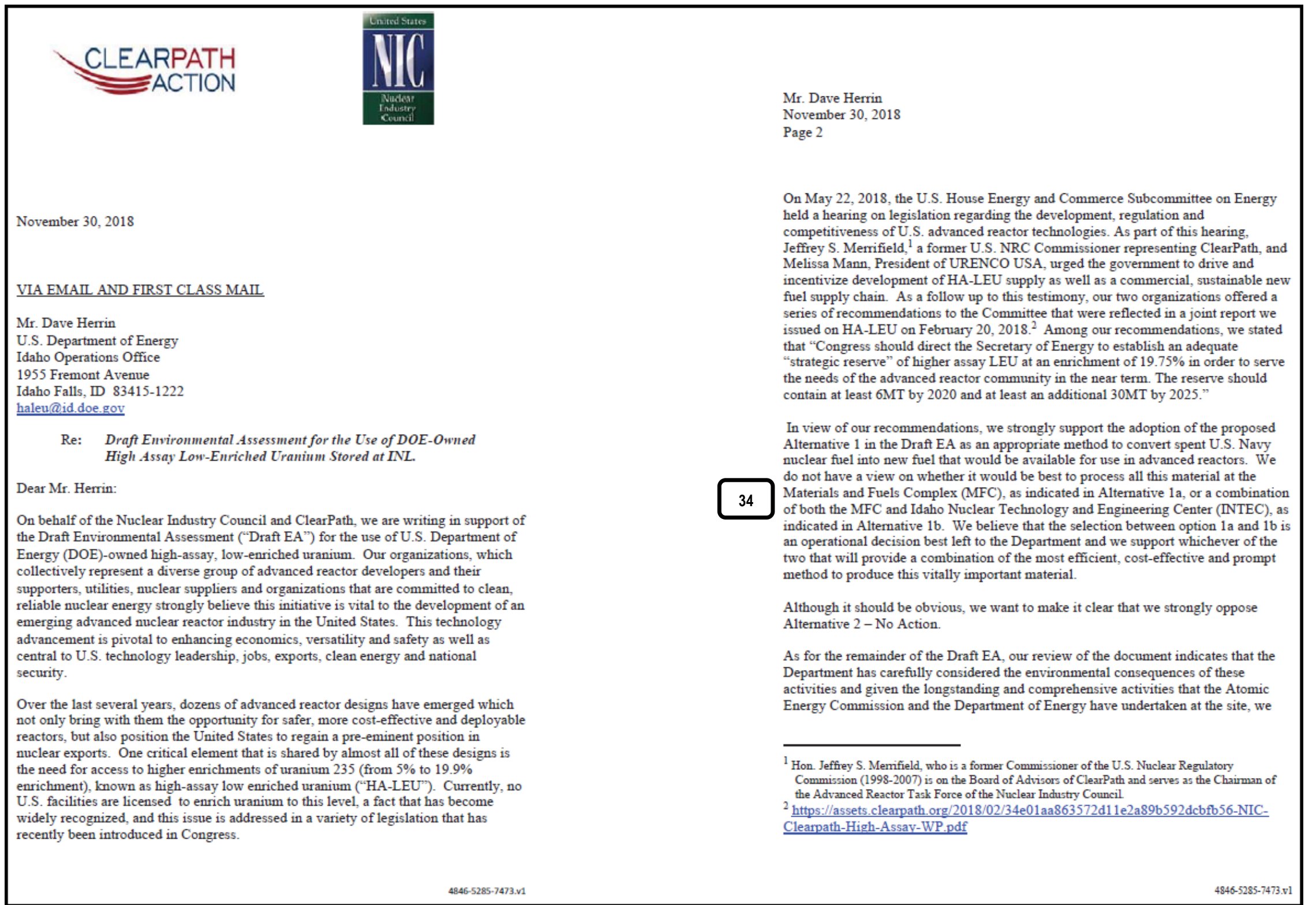


Table A-2. DOE's response to comments on the draft EA sorted by commenter.

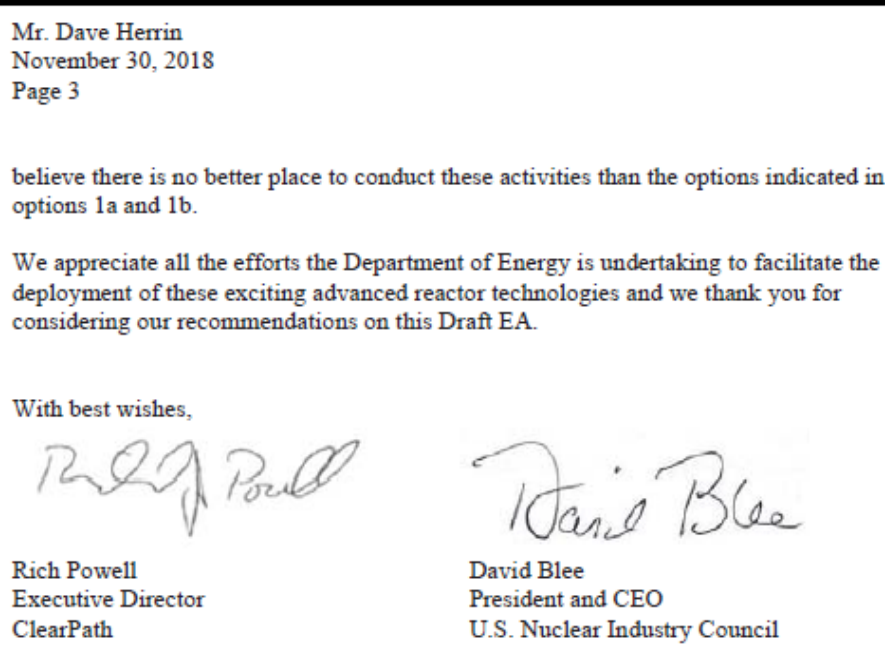

We appreciate all the efforts the Department of Energy is undertaking to facilitate the deployment of these exciting advanced reactor technologies and we thank you for

considering our recommendations on this Draft EA.

Rich Powell

Executive Director

Executive
ClearPath

David Blee

President and CEO

U.S. Nuclear Industry Council

Response(s) 34: Mr. Powell, thank you for your comments. Please refer to the numbered comments and corresponding numbered responses.

34. Conversion of U.S. Navy fuel into advanced reactor fuel is not within the scope of this EA. This EA is limited to the use of HALEU product material resulting from the electrometallurgical processing of sodium-bonded spent nuclear fuel addressed in DOE's Sodium-Bonded Environmental Impact Statement (DOE/EIS0306, 2000) and other small quantities stored at the INL. 
Table A-2. DOE's response to comments on the draft EA sorted by commenter.

\section{Peter Rickards, Self}

Comment(s) 35 - 43: Mr. Rickards, thank you for your comments. Please refer to the numbered comments and corresponding numbered responses.

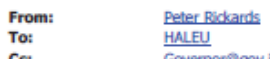

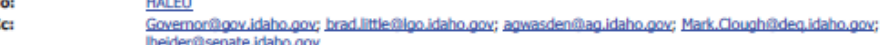

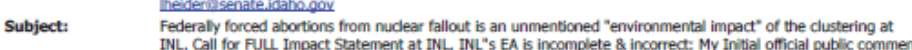

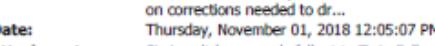

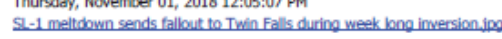

Hi DOE, INL, and David Herrin

I just received my notice from INL, asking for public comment on the unfortunately

superficial Environmental Assessmen (EA) done on the proposal to fabricate nuclear fuel for

US businesses, to experiment with at INL.

35 The EA is incomplete and the neglected issues demand a full environmental impact

statement for the plans to cluster nuclear dirty work in Idaho, listed in this EA. INL pretends criticality from a disgruntled worker does not need analysis. Even in normal operations, the dose from hyper-active plutonium-238 (pu-238) is dismissed incorrectly. Plutonium,

especially, Pu-238, knocks itself off the filters and creeps through even 4 HEPA filters in a row, into Idaho air to breath. If inhaled, just one lone particle of pu-238 exceeds the legal limit of $10 \mathrm{mrem}$, but you claim the maximum dose is $0.00000026 \mathrm{mrem}$. Hmm.

I AGAIN submit the DOE document below on HEPA filter's inability to contain plutonium238 , and the peer reviewed plutonium-238 inhalation study published in the Radiation

Protection Dosimetry journal, by the National Academy of Sciences consultant, Dr Bobbi Scott, who is well published, and actually very pro-nuclear. But Dr Scott is honest about the space battery isotope.. Both these documents contradict this flimsy EA. Both also document and contradict the so-called full Environmental Impact Statement (EIS), done in 2000, that this EA is based on. I actually called Dr Scott to be sure I understood his important paper correctly.

37 These documents implore the need for an accurately documented REAL new FULL EIS to reveal ALL the REAL "environmental impacts" of the clustering of DOE dirty work here, instead of your EA Red Carpet welcome for nuclear businesses to abuse Idaho's air, water and children..$$
\text { Specifically: }
$$

the dose to Idahoans. While a disgruntled employee caused INL's first criticality at SL-1, you simply claim that accident criticalities won't happen because of your rules. Disgruntled workers are real threat, as are accidents, so tell Idaho the truth about bad accidents. I attach the official dose reconstruction map of the fallout plume from the SL-1 criticality. The wind blew the deadly plume across southern Idaho, for a solid week, during an inversion layer. This would force the evacuation of large parts of Idaho, so stop lying to Idaho and analyze the criticality. Japan had a criticality at their uranium plant in recent times, with well trained workers, so don't pretend it won't happen. I paste parts of your accident analysis on web page(WP) $36 / 47$,

at the bottom of these comments for easy reference.
While you just analyze a spill, the worker dose is huge, $8.81 \mathrm{rem}$ per MINUTE. The dose to a worker in another area, 100 meters away is $997 \mathrm{mr}$
citizens on your "tours" potentially receive at INL?

Question: If a pregnant women was on tour, or changing a flat tire on nearby Route 20 ,

during an inversion layer, what would the dose to the fetus be? Don't doctors recommend zero

or as little man made radiation exposure as possible for pregnant women, right? The infant
Why risk a nuclear criticality that can evacuate Idaho, when we can outpower the state and coutry with renewable power, according to DOE's lab?

First politicins for lied and left $90 \%$ buried. Now they want to fabricate fuel for nuclear businesses? Ask ALI your country can do to . Now they want to fabricate fuel for muclear businesses? Ask not wht businesses that donate to our lying politicians.

Issue 2) The EA states on WP 40/47 "There are several proposed projects at the INL Site that DOE considers reasonably foreseeable that would include radiological emissions that could

contribute to cumulative impacts. Those that DOE reviewed include:

- DOE Idaho Spent Fuel Facility

Remote-Handled LLW Disposal Facility

Plutonium-238 Production for Radioisotope Power Systems

You calculate the MAXIMUM dose incorrectly, from this pu-238 PRODUCTION facility planned for INL., stated here:

WP 41/47 From Table 8 Estimated annual air pathway dose (mrem) from normal operations to the maximally exposed off-site individual from the above proposed projects

Plutonium-238 Production for Radioisotope Power Systems (DOE/EIS 2013) 0.00000026b A chest $\mathrm{x}$-ray is about $8 \mathrm{mrem}$. Then legal limit of INL is $10 \mathrm{mrem}$ each year to citizens, and 100 mrem to workers.

The uranium plant will produce pu-238, but as usual, you dismisspu-238t as a minority element not needing analysis. Please explain the contradiction between the so-called "maximum dose" from pu-238 production listed, of the tiny 0.0000025 mrem dose INL claims, and the Dr Scott paper, that says inhaling 3 particles of pu-238 can exceed the 100 mrem ALI of DOE workers. ALI- Annual Limit of Intake) 1 asked Dr Scott if he really meant 3 particles by "few" and if that meant $j$ ust one pu-23s particle inhaled could exceed the citizen limit of $10 \mathrm{mrem}$. Dr Scott said $\mathrm{I}$ was correct in my understanding. So, how dare you repeat this BS? I have entered these science based scoping questions at all EIS' scoping hearings, for decades, always unanswere

\section{littp://rpdoxfordiom mals.org/content/83/3/221.abstract}

nuppet:
The alpha-emitting isotopes 238Pu, 239Pu, 240Pu and $242 \mathrm{Pu}$ are found at Rocky Flats. Although $238 \mathrm{Pu}$ is thought to be present in relatively small amounts there, intake via inhalation of only a few $238 \mathrm{P} u \mathrm{O} 2$ particles could greatly

Variability in PuO2 Intake by Inhalation: Implications for Worker Protection at the US Department of Energy B.R. Scott A.F. Fencl

Radiation Protection Dosimetry, Volume 83, Issue 3, 1 July 1999, Pages 221232.https://doi.org/10.1093/oxfordjournals.rpd.a032676 Published: 01 July 1999

Issue 3) All DOE calculations pretend HEPA filters are $99.97 \%$ efficient and claim 4 filters in a row even more efficient. However the McDowell studies from DOE proved "alpha reco in a row even nure efree through filters, into the air we breath, way above the legal limit. Here is another DOE document on alpha recoil I pulled from the OSTI archives, and share to deaf ears \& averted eyes, in these public comments. Puery $i d=0$ \&page $=0$ \&.osti id=969795 
Table A-2. DOE's response to comments on the draft EA sorted by commenter.

Snippet: Operational experience at PufF indicates that the Pu-238 contamination was

observed to move along surfaces and through High Efficiency Particulate Air (HEPA) filters

over time. Recent research into the phenomenon known as alpha recoil offers a potential explanation

for this observed behavior. Momentum is conserved when an alpha particle is ejected from a Pu-238

atom due to radioactive decay. Consequently, the entire particle of which that Pu-238 atom is a

the particle offen fractures in response to Pu-238 atom disintegration (vielding an alphed. Furthermore,

the particle often fractures in response to Pu-238 atom disintegration (yvielding an alpha particle), with a

continuous size reduction and transport of particles containing Pu-238 atoms, thus

explaining movement of contamination along surfaces and through

HEPA filters.

Issue 4) The 1995 settlement agreement allows up to 200 acres of plutonium particle dumping. Your EA claims the waste will go offsite, but when it is legal and cheaper to dump onsite, that is required to be the actual destiny, dumped in Idaho. While the goal is to make

new fuel rods, which will turn into high level waste, Yucca Mt is not open, but you never

analyze the destiny of that waste in your dismissive EA.

This all calls for a full EIS on HEPA filters and ALL the clustering of deadly nuclear dirty

work. Peter Rickards Twin Falls, Idaho peterforidaho.com

Here is your EA tiny incomplete accident section: While you just analyze a spill, the worker dose is huge, $8.81 \mathrm{rem}$ per MINUTE. The dose to a worker in another area, 100 meters away is

$997 \mathrm{mrem}$. Isn't that the dose school children and citizens on your "tours" potentially receive?

Question: If a pregnant women was on tour, or changing a flat tire on nearby Route 20,

during an inversion layer, what would the dose to the fetus be?

WP 36/47 Accident types considered included thermal stress of fire on $50 \mathrm{~kg}$ uranium solids,

spill or free-fall drop of molten metal, and accidents resulting in solid ingot free-fall drop or

mpact (ECAR-4310). The potential for nuclear criticality exists due to the quantity and form

of material being processed. However, engineered and administrative controls would be

incorporated into the facility and process operations to prevent and mitigate worker risk

associated with this hazard.

... The handbook further states that release fractions for disturbed molten metal surface under dynamic conditions such as a spill or free-fall drop are higher than that for pieces or powder under thermal stress (fire). Therefore, the bounding and most severe postulated accident for the proposed action is a spill or free-fall drop of molten uranium during material processing.

This accident could occur from an initiating event such as natural phenomena occurrence (i.e.

severe seismic event), operator error, or from unspecified facility structural failures.

WP 38/47 Table 7 Summary of dose impacts for the highest consequence events for

Alternative 1

Facility Worker(1,700 $\mathrm{m} 3$ building $) 8.81$ (rem/ $\mathrm{min}) \mathrm{b}$

Collocated Worker (100 m downwind) 997 (mrem)c Peter: This would also be the dose to

innocent schoolchildren and citizens taking a tour of INL that day.

Offsite Member of the Public (5,000 m downwind) $29.4 \mathrm{E}$ (mrem)

Offsite Member of the Public (14,000 m downwind) 9.10 (mrem)c 
Table A-2. DOE's response to comments on the draft EA sorted by commenter.

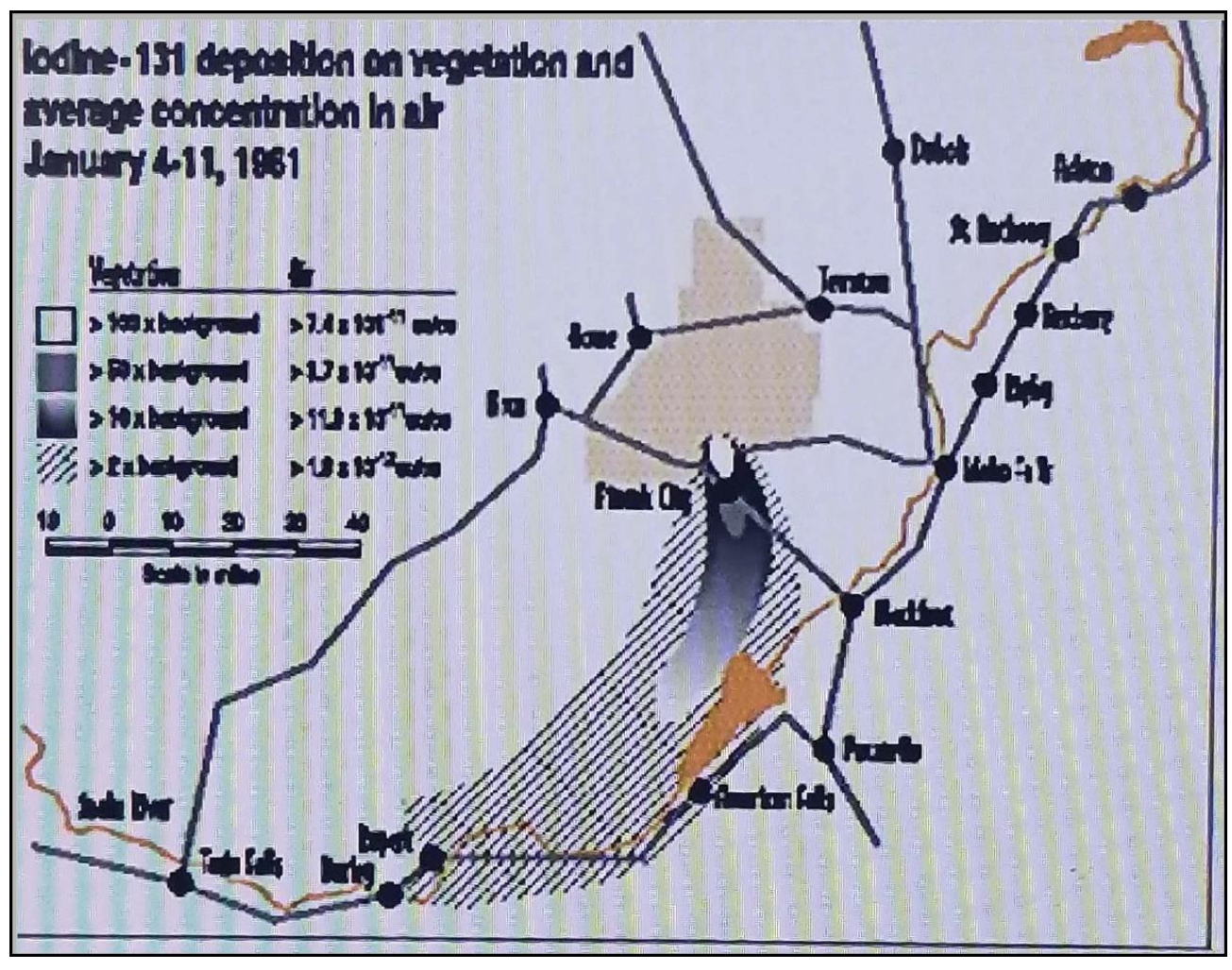

Response(s) 35 - 43: Please refer to the numbered comments and corresponding numbered responses.

35. See response to comment \#24

36. Pu-238 has not been detected using approved analytical chemistry methods and calculation to determine chemical and isotopic composition from six casting batches of HALEU feedstock material, comprising roughly $202 \mathrm{~kg}$ of uranium. The detection levels presented in the analytical results are given in weight percent (wt. \%), ppm, parts per billion (ppb), and parts per trillion (ppt). Production of Pu-238 involves nuclear irradiation of Np-237, which is not within the scope of this project. Pu-238 is not expected as a product or by-product contaminant for High-Assay Low-Enriched Uranium (HALEU) fuel development and is therefore not addressed in the subject document nor supporting dose calculation documents.

37. See response to comment \#24

38. DOE takes its responsibility for the safety and health of the workers and the public seriously. Accidental nuclear criticality is recognized as a potential hazard; however, a criticality event is extremely unlikely because a large number of independent failures would have to happen before an accidental criticality 


\section{Table A-2. DOE's response to comments on the draft EA sorted by commenter.}

could occur. DOE has multiple engineered and administrative controls in place to prevent these failures. In the unlikely event of an accidental criticality, the potential dose to the public is bounded by the accident analysis in the EA. Intentional destructive acts are discussed in the EA (see Section 4.1.5).

Accidental nuclear criticality is recognized as a hazard primarily from direct radiation exposure to workers within the affected area. Through a combination of engineered and administrative controls, potential dose to the public is bounded by the accident analysis in the EA.

In criticality safety assessments, the uranium enrichment and material/fuel density are considered explicitly and independently of each other. Therefore, derivation of an effective uranium enrichment based on uranium density is not necessary. As discussed in the EA, engineered and administrative controls would be incorporated into the facility and process operations to prevent and mitigate worker risk associated with a criticality. Derivation of these controls would be informed directly from a criticality safety assessment for the process.

39. The worker dose referred to as 8.81 rem is actually a conservative estimate of committed effective dose to the worker over 50 years - per minute of exposure to the accident conditions. Worker training dictates the reasonable response that in a catastrophic accident, the affected area is immediately evacuated, which is the basis for the assumption as stated in ECAR-4310, to the effect that a worker would evacuate the affected area in less than one minute following an accident. The 8.81 rem committed dose per minute of exposure equates to approximately 176 millirem per year averaged over the 50 years. This dose rate is less than that associated with natural terrestrial and cosmic radiation exposure rates encountered in everyday living. Likewise, the 997 mrem accident-induced committed dose referred to for a collocated worker at 100 meters results in approximately 20 mrem per year average over 50 years, which is well below radiation dose from natural sources over the same time. By comparison, 10 CFR Part 20 limits annual whole body total effective dose equivalent to $5,000 \mathrm{mrem}$ ( $5 \mathrm{rem}$ ) whole body radiation exposure for radiation workers.

40. The scope of this EA does not include Pu-238 production (see response to comment \#34). The potential consequences of Pu-238 production noted in the comment were addressed previously approved in DOE/EIS-0310.

41. The phenomena discussed in the referenced documents are specifically applicable to Pu-238 due primarily to high decay heat and radiologic decay mode of that isotope. The documents cited address work at Savannah River in the 1970s and 1980s in production of and subsequent clean up from Pu-238 production. The work scope included in this EA does not involve Pu-238 and the comment has no relevant context to HALEU fuel development. Pu-238 has not been detected or derived by calculation to be present in materials to be used in HALEU fuel development and has therefore not been addressed nor analyzed in this EA. The analyses presented in the EA represent maximum hypothetical doses and do not credit administrative and engineering controls, including HEPA filtration. Nevertheless, HEPA filtration is an effective means to control release of particulate radionuclides and will continue to be used as an engineering control to protect workers and the public.

42. DOE has made no decision on the specific use of the fuel. The fuel could be used in advanced reactor design or for the purpose of research and development. DOE will work with other Federal agencies and commercial vendors to determine use of HALEU fuel. Any reactors that use the HALEU fuel addressed in this EA will require their own NEPA review which would include disposition of spent nuclear fuel and other waste.

43. See Comment/Response \#39 
Table A-2. DOE's response to comments on the draft EA sorted by commenter.

\section{Ann Rydalch, Self}

Comment(s) 44:

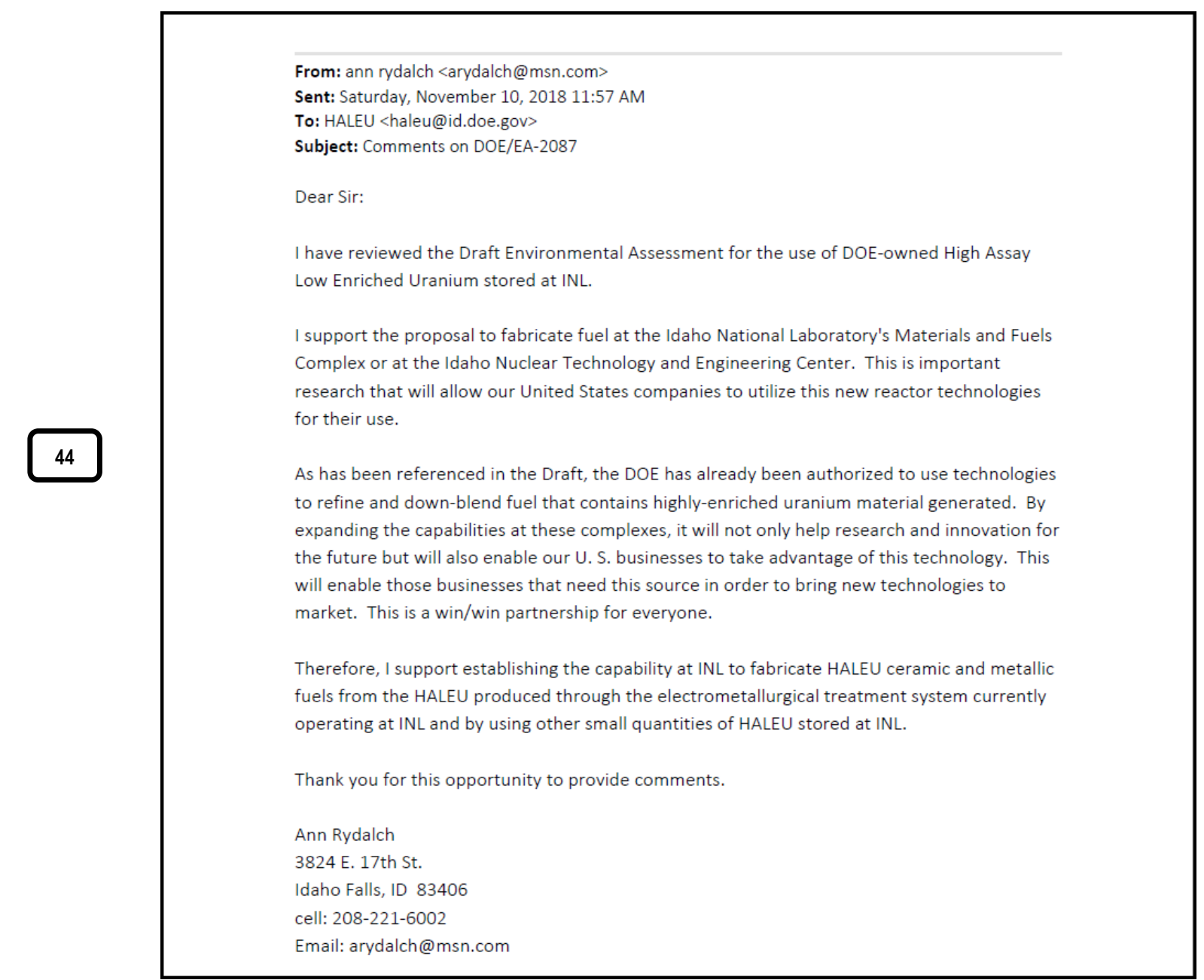

Response(s) 44: Ms. Rydalch, DOE acknowledges your comment supporting the proposed action. Thank you. 
Table A-2. DOE's response to comments on the draft EA sorted by commenter.

\section{Abhijit Sengupta, Self}

Comment(s) 45 - 49: Mr. Sengupta, thank you for your comments. Please refer to the numbered comments and corresponding numbered responses.

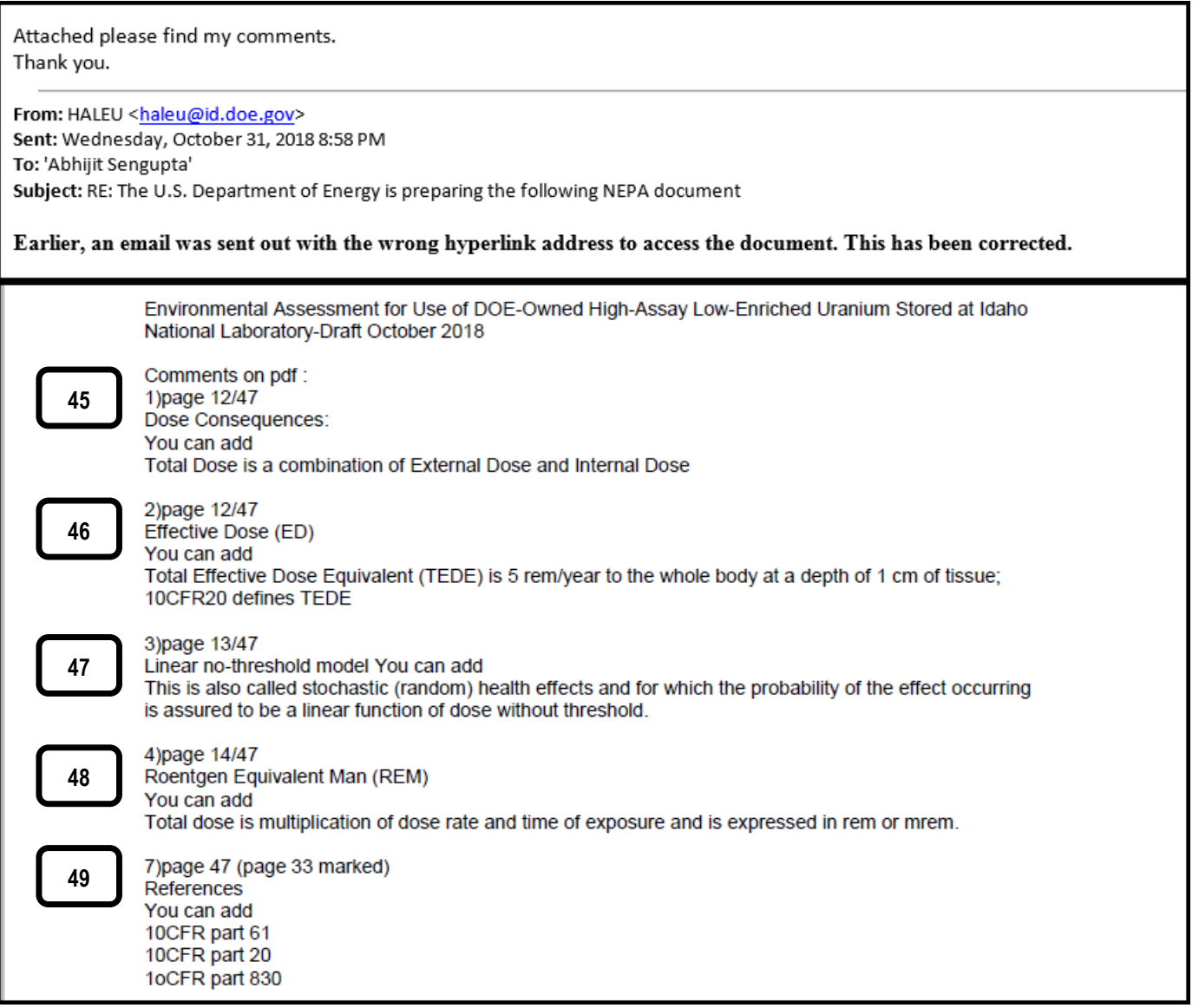

Response(s) 45 - 49: Mr. Sengupta, thank you for your comments. Please refer to the numbered comments and corresponding numbered responses. 45. The definition of dose has been changed to clarify that dose is due to external and internal radiation.

46. While the suggested text is a regulatory limit for the TEDE, it is not a description of the term. Regulatory limits are discussed in the document.

47. The definition is correct and further clarification is deemed not necessary.

48. The definition is correct and further clarification is deemed not necessary.

49. Appropriate references (e.g., CFRs) were added to the EA where missing. 
Table A-2. DOE's response to comments on the draft EA sorted by commenter.

\section{Tami Thatcher, Self}

\section{Comment(s) 50 - 63:}

Public Comment Submittal on the U.S. Department of Energy Draft

Environmental Assessment for Use of DOE-Owned High-Assay Low-Enriched

Uranium Stored at Idaho National Laboratory

Comment submittal by Tami Thatcher, November 30, 2018.

The draft DOE/EA-2087 is at

https://www. id.energy. gov/insideNEID/PDF/Draft\%20HALEU\%20EA.pdf

These comments address the proposal by the U.S. Department of Energy to fabricate nuclear reactor fuel from DOE-owned high assay low-enriched uranium (HALEU) currently stored at the Idaho National Laboratory. The DOE would process 10 metric tons of the enriched uranium at a rate of $5 \mathrm{MT}$ per year. The processing could be at two facilities at the Materials and Fuels Complex or two facilities, one at MFC and one at the Idaho Nuclear Technology and Engineering Center (INTEC)

The Environmental Assessment, besides relying on fiction in many cases, is so inadequate hat a full environmental impact statement must be performed.

Importantly, the EA relies on previous environmental impact statements that presume the existence of a non-existent spent nuclear fuel (SNF) and high-level waste repository. The Department of Energ is preto soon and herefore sho do make even more spent fuel. And the DOE is using the lack of a repository as an excuse for failing to prepare the SNF and HLW as the Idaho National Laboratory for shipment to a repository such as
the proposed Yucca Mountain repository.

The EA fails to grapple with reality on so many fronts that it is an insult to the intelligence of anyone who follows what is actually going on. Protecting workers, the public and the

environment is not achieved by strict adherence to the retelling of untruths. Relying on out-ofdate EISs that don't represent the lack of progress toward a repository for spent nuclear fuel and high-level waste and DOE's failure to update radiological health models and standards cannot possibly achieve the stated goals of conducting NEPA analysis.

And by the way, there are $1000 \mathrm{~kg}$ in a metric ton. And there are $2.2 \mathrm{lb}$ in a kg. And that would have been appropriate to include in the EA, but it wasn't

Problems with Obtaining a Nuclear Waste Repository for Spent Nuclear Fuel and HighLevel Waste

There is considerable lack of understanding by the public about the longevity and toxicity of long-lived radiative waste. It is not like natural uranium and thorium bound up in rock. The

longevity and toxicity of radionuclides that dominant repository contamination migration studies include, for example, chlorine- 36 ( 301,000 year), iodine- 129 (17,000,000 year), technetium- 99 (213,000 year), uranium-234 (245,500 year), neptunium-237 ( $2,144,000$ year), americium-241 ( 432 year but decays to $\mathrm{Np}-237$ ), plutonium-238 ( 87.7 year but decays to U-234), plutonium-239 (24,000 year but decays to $\mathrm{U}-235$ ). We are not talking about a mere 150,000 years of radiotoxic material. The 10,000-year timeframe once proposed for Yucca Mountain was never adequate. And, even the one-million-year analysis timeframe for the waste migration may not be sufficient. The stable end product for uranium, thorium and plutonium is lead which is not good to have in your water either.

The actinides such as uranium decay in a long string of decays known as a decay chain. ${ }^{1}$ Uranium-238, for example, decays to thorium-234 which decays to protactinium-234 which decays to uranium-234 which decays to thorium- 230 which decays to radium- 226 which decays to radon- 222 which decays to polonium- 218 which decays to lead-214 which decays to bismuth214 which decays to polonium-214 which decays to lead-210 which decays to bismuth-210 which decays to polonium-210 which decays to lead-206 which does not decay anymore because it is "stable."

The Yucca Mountain repository is destined to fail because the geology of the porous mountain located above groundwater does not isolate the spent nuclear fuel which is not protected from corrosion. The low radiation doses from ingestion of contaminants from the proposed Yucca Mountain repository rely on titanium drip shields which have not been designed nor has the method for their installation been developed. It may be impossible to robotically install the relied upon titanium drip shields in the dusty, collapsing tunnels after a few centuries of cooling the SNF. Any realistic assessment of the likelihood of failure to install the titanium drip shields or failure of their adequate performance has not been included by the NRC's optimistic study of contaminant migration from Yucca Mountain. The NRC was supposed to review the Department of Energy's Yucca Mountain submittal but ended up preparing the cornerstone estimate of the repository's estimated radionuclide releases.

The geology of Yucca Mountain does not prevent corrosion of the SNF or its containers and does not prevent the migration of radionuclides into nearby watersheds. The technology to monitor or retrieve the spent fuel does not exist. ${ }^{3}$ 
Table A-2. DOE's response to comments on the draft EA sorted by commenter.

Arguments that migration of the contaminants from the repository will be acceptably low hinge on the assumed protection of 1,500 5-ton titanium drip shields to be robotically installed after the waste is in place. ${ }^{45}$

(Footnotes continued) 67891011

" State of Nevada, Office of the Governor, Agency for Nuclear Projects, "Report and Recommendations of the Nevada Commission on Nuclear Projects." December 10, 2010.

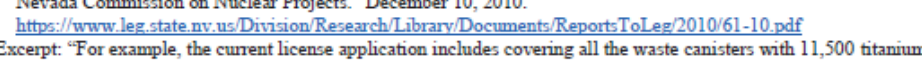
Excerpt: "For example, the curent license application includes covering all the waste canisters with 11,500 titanium
drip shields to protect them from rock fall and highly corrosive groundwater. But the drip shields themselves (estimate to cost $\$ 12$ billion or more) are only proposed to be installed 80 to 100 years affer the waste is put into the mountain, using yet-to-be developed robotics due to the extreme thermal and radiological environment that would exist within the emplacement tunnels. Despite this, potentially disqualifying conditions were revealed at

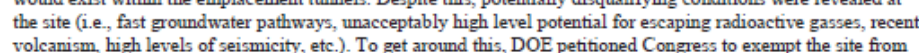
volcanism, high levels of seismicity, etc.). To get around this, DOE pethoned Congress to exempt the site fir
health and safety regulations and then scrapped its own site evaluation guidelines altogether." Another excerpt. 'It posits the existence of titanium alloy 'drip shields', one 5-ton dip shield over each of the 11,500 waste packages, to ward off the conrosion-promoting water. However, these extremely expensive drip
shields are not part of the current waste installation plan but are intended to be installed by a yet-to-be-designed, shields are not part of the current waste installation plan but are intended to be installed by a yet-to-be
remote-controlled robotic mechanism about one hundred years after the wastes have been emplaced."

The Department of Energy was planning to use a consent-based approach for siting spent nuclear fuel and highThe Department of Energy was planning to use a consent-based approach for siting spent nuclear fuel and high-
level waste storage and disposal facilities including: (1) a pilot interim storage facility, (2) consolidated interim storage facilities, and (3) permanent geologic disposal faci.
other for defense spent nuclear fuel and high-level waste.

other for defense spent nuclear fuel and high-level waste.
consent-based approach was recommended in the 2012 Blue Ribbon Commission report on the nation's problem of spent nuclear fuel disposal, but no one knows what a consent-based approach entails. What we do know that geologic waste disposal at Yucca Mountain at Nevada and prevented a proposed interim storage site at Skull Valley, Utah The DOE held meetings in 2016 around the county seeking public input on the consent-based process, including one in Boise, Idaho. The Department of Energy successfully disposed of the consent-based approach and the public 2017 .

of majonity of the spent nuclear fuel is from commercial electricity generation from US nuclear power plants. As
of 2013 , there was 70,000 metric tons heavy metal, enough for the symied Yucca Mountain repository. The inventory is expected to roughly double as the existing fleet of US nuclear reactors operates for its expected life. Utilites are winning billions in compensation from the DOE over the conthnuing costs of storing the spent nucle
fuel because of the DOE's fallure to provide a d

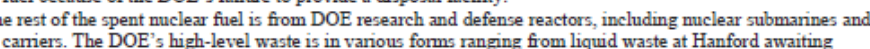
vitifification, highly soluble powder-like calcine at Idaho and vitrified waste as other sites.

"Before ending the consent-based siting effort, information found about the Department of Energy's consent-based

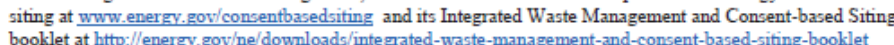

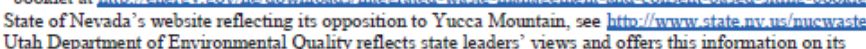
"Utah Department of Envirionmentala Quality reflects state leaders' views and offers this information on its
"opposition to storage of

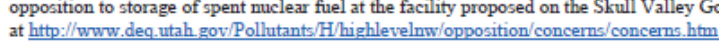

Yucca Mountain Emvionental Impact Statement, DOEEEIS-0250F-S1.

Department of Energy Strategy for the Management and Disposal of Used Nuclear Fuel and High-Level Radioactive Waste, January 2013. p. hittp://energy.gov/em/dowuloads/strategy-management-and-disposal-used

nuclear-fuel-and-hiph-level-radioactive-waste

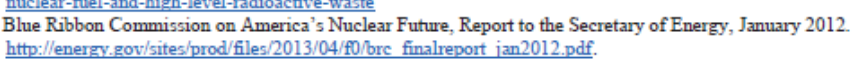

Despite any appearance of progress toward a repository, there are numerous ways that removal of spent nuclear fuel from the Idaho National Laboratory and other stranded fuel sites may continue to be delayed: failure to grant a license for permanent storage, delayed licensing, continue to be delayed: failure to grant a license for permanent storage, delayed licensing,
construction delays, lack of funding, delays in licensing or procuring transportation overpacks, or an accident that causes an interruption in shipping. Needed roads and railways don't necessarily connect the utility to the highway or railway or may be inadequate for the heavy loads.

The Tardiness of DOE to Treat Sodium-Bonded Spent Nuclear Fuel at the INL Is Obscured in the EA and Failure to Meet Idaho Settlement Agreement

The EA referenced the Sodium-bonded fuel EIS ${ }^{12}$ but the EA fails to mention that the DOE has conducted treatment of the EBR-II SNF at a snail's pace and has slowed to an average pace of only about 0.1 metric tons heavy metal (MTHM) per year. ${ }^{13}$

Importantly, the December 2017 report by the U.S. Nuclear Waste Technical Review Board (NWTRB) points out that the Department of Energy continues to fail to take actions to find disposal for the EBR-II wastes. The NWTRB finds that the fate of the treated sodiumbearing waste streams is uncertain. The EA presents to the public a rosy picture that is not consistent with the facts.

'Because DOE-NE is not a 'waste custodian' and, hence, is not subject to the waste acceptance system requirements that apply to all SNF and HWL that will be disposed in a repository, the fate of these waste streams is uncertain," writes the NWTRB in its December 2017 report, "Management and Disposal of U.S. Department of Energy Spent Nuclear Fuel."

Beyond the spent nuclear fuel that the Idaho Settlement Agreement ${ }^{14}$ requires be repackaged using a facility that has not been built in order to be shipped out of Idaho by 2035, the High Level Waste (HLW) at the INL includes the calcine and the remaining to be treated liquid sodium-bearing waste. Both the calcine and the SBW will require another expensive round of processing into canisters that can be shipped out of the state and meet disposal requirements for the yet-to-be-named defense repository.

The DOE continues on a path to miss all future Idaho Settlement Agreement milestones for treating, packaging and shipping spent nuclear fuel and high-level waste out of Idaho and the EA

${ }_{12}^{12}$ U.S. Department of Energy Sodium Bonded Environmental Impact Statement, DOEEIIS-306, July 2000.

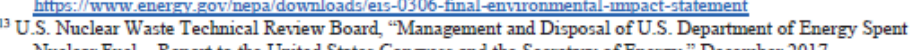

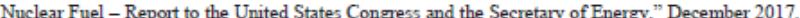
hittp://www.nwtrb.gov/our-work/reports/management-and-disposal-of-us.-department-of-energy-spent-nuclearfivel-(december-2017)

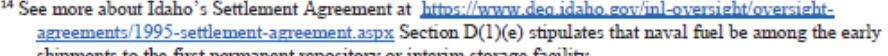
shipments to the first permananent repository or interim storage facility. 
Table A-2. DOE's response to comments on the draft EA sorted by commenter.

\section{must not hide the numerous serious failures of the Department of Energy to meet these important} must not hide
milestones. ${ }^{15}$

The Evidence Shows That DOE Doesn't Comply with Its Regulations or State Regulations The EA reads like a propaganda brochure, stating "DOE uses engineered and administrative controls to make work safe and to reduce the potential for environmental consequences of its operations."

To start off, let's look at the statement in the EA about the Department of Energy following its own regulations: "Activities that affect, or may affect, the safety of DOE nuclear facilities must also comply with the requirements of 10 CFR 830, Nuclear Safety Management."

Anyone familiar with the two accidents at the Waste Isolation Pilot Plant (WIPP) in New Mexico in 2014 knows how DOE was failing in nearly all programs for safety at WIPP to provide adequate funding, oversight, or technically valid decision-making regarding nuclear safety at WIPP

WIPP's original safety basis had been extensively reviewed, more than any other DOE facility. Reviews by the Environmental Protection Agency and by the Defense Nuclear Facility Safety Board had been conducted. But subsequent changes to the WIPP safety basis, approved by DOE had reduced safety significantly. They made the assumption that a roof fall would never occur in an open panel and had no accident analysis for this. WIPP experienced a roof fall within a couple months of not bolting the ceiling in the underground mine. The accident investigation report also discovered that far more plutonium/americium was released from a single drum in the February 12,2014 event than the safety analysis predicted was possible. ${ }^{16}$

Anyone familiar with the numerous workers exposed to inhalation of plutonium and americium from ZPPR fuel plates for several minutes from the 2011 accident at the Materials and Fuels Complex knows that the DOE was not conducting and implementing adequate nuclear safety analysis or other safety programs to protect workers. In the 2011 ZPPR facility management

is See more about Tdaho's Settleme

Dapreements/1995-settlement-agreenuet ant at

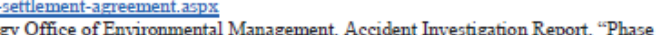
Radiological Releases Event at the Waste Isolation Pilot Plant February 14,2014," April 2015 .

http://wipp.energy.zov/Special/AIB WIPP\%20Rad Event\%20Report Phase\%20II.pdf See Sections 7.1 and 7.2. The release was found to have been from a single drum with stated inventory in plutonium- 239 equivalent curies of 2.84 PE-Ci. But based on contamination on filters at Station $A$ of 0.1 curies PE-ci far from the
exploded drum in Panel 7 , using conventional safety analysis assumptions the expected amount of material exploded drum in $\mathrm{Panel} 7$, using conventional safety analysis assumptions the expected amount of material
released to Panel 7 would not have exceeded $2.84 \mathrm{E}-4 \mathrm{PE}-\mathrm{Ci}$ - far less than what was measured downstream Station $A$. The inventory in the drum appears to have been much higher than stated for WIPP drum and the release factions may also be incorrect. This discrepancy in the transuranic inventory of the drum is in addition to the fact that forbidden inorganic "Kitty litter" absorbent was placed in the drum which allowed an explosive combination of nitrates and organics. In my view, the extent to which the stated transuranic inventory was
understated and actually not known does not appear to be adequately addressed by corrective actions recommended in the report. Alpha is difficult to monitor and easily shielded: DOE does not want you to kno the degree that they say is in the drums may not conservatively bound what is actually in the drums. 
Table A-2. DOE's response to comments on the draft EA sorted by commenter.

configured constant air monitor failed to identify the contamination. That curious lack of curiosity about why the elevated levels of airborne contamination was not identified until weeks

later when contamination was found on constant air monitor filters and the DOE contractor

inexplicably decided that no causal analysis was needed.

Radiation Workers at INL Have Not and Are Not Being Adequately Protected Radiation worker training today still implies that a 5 rem annual dose would not be harmful even though radiation worker epidemiology has indicated elevated health risks at doses ten times less than 5 rem annually. ${ }^{21}{ }^{22}$ Radiation workers are still not warned of reproductive health risks suct as sterility or increased risk of bith defects. ${ }^{23} 24$

The Department of Energy contractors who can be fined for workers getting excessive radiation exposures are in charge of conducting radiation dose assessment as well as handling samples and records used to estimate the radiation dose. Most workers do not understand the wide latitude allowed in making assumptions that can bias radiation dose estimates, nor the large uncertainty in the dose estimates. ${ }^{25}$

Investigations conducted of historical INL operations for energy worker illness compensation during the last two years have found shattering revelations about inadequate worker protections at the INL especially regarding inhalation of alpha emitters such as plutonium and the inability to estimate what doses these workers had received. The investigations partially include the early

${ }^{4}$ Richardson, David B., et al, "Risk of cancer from occupational exposure to ionizing radiation: retrospective cohort study of workers in France, the United Kingdom, and the United States (INWORRS), BMJ, v. 351 study that included a cohort of over 300,000 nuclear industry workers has found clear evidence of solid cancer study that included a cohort of over 300,000 nuclear industyy workers has found clear evidence of solid cancer
risk increases despite the average exposure to workers being about 2 rem and the median exposure was just 410
millirem. Also see December 2015 EDI newsletter.

Email communication with INL's public relations and Director Mark Peters confirmed that radiation worker training did not include training about recent epidemiology indicating higher health risk following Peter's
editorial in the Post Register on January 3. 2016 that promised more transparency, "Neww INL director lools editorn.

$\checkmark$ See the September EDI newsletter p. 2 and Kate Brown, Plutopia - Nuclear Families, Atomic cities, and the Great Soviet and American Plutonium Disasters, Oxford University Press, 2013. ISBN 978-0-19-985576-6. Note that many publications use spelling variation Mayak instead of Maiak

14 "Health Risks from Exposure to Low Levels of Ionizing Radiation BEIR VII - Phase 2, The National Academies of the prior report that every exposure to radiation produces a corresponding increase in cancer risk. The BEIR VII report found increased sensitivity to radiation in children and women. Cancer risk incidence figures for solid tumors for women are about double those for men. And the same radiation in the first year of life for boys produces three to four times the cancer risk as exposure between the ages of 20 and 50 . Female infants have
almost double the risk as male infants. BEIR VII findings are not included in Department of Energy radiation

worker training, nor are the findings included in public radiation protection standards.

"See the March 2017 EDI newsletter "How DOE underestimates the harm of plutonium inhalation," at
hitto://www. environmental-defense-institute org publications NNews. 17. March.pdf and other newsletters decades of INL operation until the 1980s but have not investigated all years of operation. 262728 2930313233 Yet, as these studies for the National Institute for Occupational Safety and Health have begun to allow more workers to obtain compensation, many more studies need to be completed for various INL facilities and various years of operation. Roughly two thirds of INL illness compensation claims have been denied and these workers or their eligible survivors may die before the studies are complete.

The EA for HALEU fuel production pretends that workers have not been harmed and are not currently being harmed. The Department of Energy continues to fail to update the way radiation dose is calculated, choosing to ignore the more insoluble forms of radionuclides that are retained longer in the lungs and provide a higher dose than DOE is estimating by ignoring Super S class insolubility. The doses to the public are similarly underestimated.

The retention of particles in the lungs is greater when the particles are more insoluble. DOE has known for years that highly insoluble plutonium, called Super S class, stays in the lungs longer the regular insoluble plutonium. But DOE does not account for Super S class even though worker compensation dose assessments do. Acknowledging Super S class could raise the dose and thus the severity of the inhalation. ${ }^{34} \mathrm{So}$, the DOE contractors have permission to underestimates lung count results by ignoring Super $\mathrm{S}$ class, by delaying lung counts, by using very coarse methods to estimate chest wall thickness and muscle to fat ratio, by improper position of the detector over the lugs and by the selection of he satitical inetrod istical methods which
nt results from workers workers.

${ }^{6}$ See the EDI September 2017 newsletter and the Advisory Board on Radiation and Worker health meetings webpage for August 2017 at https $/ /$ www. cdc. gov/niosh/ocas/pubn
Laboratory SEC Evaluation Report SEC-00238 from that page at

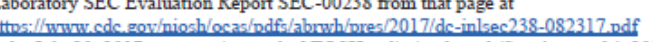

${ }^{27}$ See the July 20,2017 presentation to the NIOSH radiation board (See August 14, 2017 board meeting) describing rarious problems t the Ldato National Labortory's NTEC prior to 1981 t

vanous problems at the idaho National Laboratory's INIEC

${ }^{28}$ NLL May 2, 2016 NIOSH Radiation Advisory board recommended Special Exposure Cohort

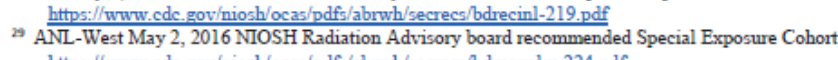

${ }^{30}$ See p. 19 of "INL SEC Proposed Class - Update SEC00219" at

hetros//

${ }^{31}$ See EDI's June 2017 newsletter article "Why so wrong for so long?"' at http:///www. environmental-defense-

institute. org publications/News.17.June.pdf

SC\&A, Inc., "Draft Review of NIOSH's Evaluation Report for Petition SEC-00219, Idaho National Laboratory. Burial Ground, 1952-1970," SCA-TR-2017-SEC007, May 2017.

Department of Labor presentation August 2017 https://www.cdc.gov/niosh/ocas/pdf/abrwh/pres/2017/dol.

4 See our EDI newrletter. for Mas

ar arcle "How DOE Underesinges the Harm of Plutonium Inhalation" Moderate Solubility, Class S Insolubility, and Super S Class Insolubility on p. 16 . 
Table A-2. DOE's response to comments on the draft EA sorted by commenter.

At the INL, particle size may be assumed to be 5 um-AMAD. ${ }^{35}$ But it is widely known that the actual particle size may be 1 um-AMAD oxide fuels at DOE facilities. ${ }^{36} \mathrm{~A}$ higher dose results for the smaller particle size if the material is insoluble and the basis for INL's use of the particle for the smaller particle size if the material is insoluble and the basis for INL's use of the part
size that lowers the estimated radiation dose needs to be supported by particle size analysis.

Table 1 gives a rough idea (but out-of-date) of the variation of the committed dose coefficients for an intake of a plutonium mixture at a weapons lab. The dose coefficient is used to estimate the total dose. The dose coefficient is highest for an intake directly into the blood. For dose to the bone, the dose from a moderately soluble mixture is about 5 times higher than the dose from a Class $\mathrm{S}$ solubility which more slowly enters the blood stream. The dose to the bone from a moderately soluble mixture is 16 times the dose of Super S solubility class. So, an assumption of moderate solubility would be conservative for all cases except those involving a very rapid intake such as a wound.

An assumed moderate solubility with 5 um particles in appropriately conservative unless the behavior is that of an instant uptake. But what INL has done is to assume the least conservative intake based on $5 \mathrm{um}$ Class $\mathrm{S}$ while the material is very likely $1 \mathrm{um}$ and may be Super Class $\mathrm{S}$

Table 1. Committed Dose Coefficients for Acute Intake of 20-Year Aged Weapons-grade mixture (rem/nanoCuries).

\begin{tabular}{|c|c|c|c|c|c|c|c|}
\hline \multicolumn{8}{|c|}{ Source: PNNL-MA-860, Issued January 2003. ${ }^{37}$} \\
\hline \multirow[b]{2}{*}{$\begin{array}{l}\text { Organ or } \\
\text { Tissue }\end{array}$} & \multirow[t]{2}{*}{$\begin{array}{l}\text { Instant } \\
\text { Uptake }\end{array}$} & \multicolumn{2}{|c|}{ Class M Inhalation } & \multicolumn{2}{|c|}{ Class S Inhalation } & \multicolumn{2}{|c|}{$\begin{array}{l}\text { Super S Class } \\
\text { inhalation }\end{array}$} \\
\hline & & 1-um & 5-um & 1-um & 5-um & 1-um & 5-um \\
\hline Effective & $3.8 \mathrm{E}+00$ & 4.7E-01 & 4.8E-01 & $3.3 \mathrm{E}-01$ & $1.4 \mathrm{E}-01$ & $5.9 \mathrm{E}-01$ & $2.2 \mathrm{E}-01$ \\
\hline Bone & $7.1 \mathrm{E}+01$ & $8.5 \mathrm{E}+00$ & $9.3 \mathrm{E}+00$ & $3.3 \mathrm{E}+00$ & $1.7 \mathrm{E}+00$ & $9.6 \mathrm{E}-01$ & $5.7 \mathrm{E}-01$ \\
\hline $\begin{array}{l}\text { Red } \\
\text { Marrow }\end{array}$ & $5.5 \mathrm{E}+00$ & $6.6 \mathrm{E}-01$ & $6.1 \mathrm{E}-01$ & $2.6 \mathrm{E}-01$ & $1.3 \mathrm{E}-01$ & $7.4 \mathrm{E}-02$ & $4.4 \mathrm{E}-02$ \\
\hline Liver & $1.3 \mathrm{E}+01$ & $1.5 \mathrm{E}+00$ & $1.6 \mathrm{E}+00$ & $6.0 \mathrm{E}-01$ & $3.0 \mathrm{E}-01$ & $1.9 \mathrm{E}-01$ & $1.1 \mathrm{E}-01$ \\
\hline Lung & insig. & $6.3 \mathrm{E}-02$ & $2.3 \mathrm{E}-02$ & $1.2 \mathrm{E}+00$ & 4.2E-01 & $4.4 \mathrm{E}+00$ & $1.6 \mathrm{E}+00$ \\
\hline Gonads & $1.0 \mathrm{E}+00$ & $1.3 \mathrm{E}-01$ & $1.4 \mathrm{E}-01$ & $4.8 \mathrm{E}-02$ & $2.9 \mathrm{E}-02$ & $1.3 \mathrm{E}-02$ & $8.5 \mathrm{E}-03$ \\
\hline
\end{tabular}

\section{di.}

b. Particle size of 1-um or 5 -um where um is micro-meter activity median aerodynamic diameter

d. The CDC recognizes Super Class S for energy worker illness compensation calculations. See cdc.gov.

35 micro-meter activity median aerodynamic diameter, indicated here as 5-um-AMAD.

Wo Gofman, MD, Radiation and Human Health, Siema Club Books, 1981, p. 490 Gofman wites that when plutonium oxide is prepared for the pupose of making fuel rods, the particle sizes are in the 1-mircron range, perfectly suited for respiratory toxicity.
${ }^{3}$. Carbaugh et al, Pacific Northwest $\mathrm{N}$.

Nothe Hanford Internal

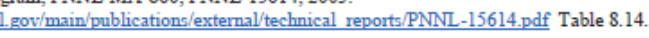

High levels of insoluble uranium often accompany plutonium intakes. While official estimates of cancer risk for the uranium dismiss the cancer risk of the uranium intake, the heavy metal stress and ionizing radiation from the multiple uranium decays causes serious stress on the body. A final suggestion to radiation workers, especially those who may be exposed to plutonium or uranium inhalation: have your children before you become a radiation worker. The elevated risk uranium inhalation: have your children before you become a radiation worker. The elevated risk
of serious birth defects from ionizing radiation including internal alpha emitters is ignored by the of serious birth defects from ionizing radiation including internal alpha emitters is ignored by the Department of Energy but should not be ignored by workers, of either gender, who plan to
become parents. The birth defects of children of people with depleted uranium intakes has been documented in Gulf War veterans and in regions contaminated with artillery-use depleted uranium. ${ }^{38} 39$

The retention of particles in the lungs is greater when the particles are more insoluble. DOE has known for years that highly insoluble plutonium, called Super S class, stays in the lungs longer the regular insoluble plutonium. But DOE does not account for Super S class even though worker compensation dose assessments do. Acknowledging Super S class could raise the dose and thus the severity of the inhalation. ${ }^{40} \mathrm{So}$, the DOE contractors have permission to underestimates lung count results by ignoring Super $\mathrm{S}$ class, by delaying lung counts, by using very coarse methods to estimate chest wall thickness and muscle to fat ratio, by improper positioning of the detector over the lungs and by the selection of the statistical methods which are biased toward not finding a positive result. And beyond all of that, it appears that over the years that the DOE contractors have also manipulated the results to achieve the desired outcome. The lung count results may have been lowered in order to say you did not have a significant inhalation of actinides.

Bioassay analysis of urine and fecal samples can detect lower levels of intakes. It has long been recognized for the low but chronic inhalation of actinides, bioassay could detect intake when lung counts could not. The detection of radioactivity above expected background levels in urine and fecal samples reveals that a detection occurred. The activity in the bioassay (in disintegrations per second or curie) is then used in a variety of creative ways that allow the estimation of actinide intake to be as low as the DOE contractor wants the intake to be. The contractor can claim to follow official ICRP models and come up with any internal dose, ranging from $10 \mathrm{mrem}$ to $30,000 \mathrm{mrem}$, whole body. ${ }^{4142} \mathrm{So}$, the internal dose assessment based on

${ }^{3}$ Depleted Uranium Education Project, "Metal of Dishonor Depleted Uranium -How the Pentagon Radiates Soldiers and Civilians with DU Weapons," 1997.

"R Bertell, Intemational Joumal of Health Services, "Depleted Uranium: All the Questions About DU and Gulf

to See our EDI newsiletter for March 2017 for article "How DOE Underestimates the Harm of Plutonium Inhalation" at http:///wwww.environmental-defense-institute. org publications/News.17.March.pdf See a table that compare Moderate Solubility, Class S Insolubility, and Super S Class Insolublity on p. 16.

Cissessing internal exposure in the absence of an appropriate model: two cases involving an incidental inhalation of transuranic
htths://doi org $10.1051 /$ radiopro:2008014 and see at

http://www.iaea.org/inis/collection/NCLCCOllectionStore/ Public/43/004/43004048.pdf See our EDI newsletter for March 2017 for article "How DOE Underestmates the Harm of Plutonium Inhalation" at hlttp://wwww.environmental-defense-institute orgepoublications News. 17. March.pdef 
Table A-2. DOE's response to comments on the draft EA sorted by commenter.

bioassay results should not be comforting to the worker. The worker must obtain the bioassay results of the amount of activity and the nuclides occurring that are above expected background levels.

Workers are routinely denied access to their lung count reports, their internal dose assessment based on upper bound lung count intakes, their bioassay reports of nuclide and activity found, and their final internal dose assessment. DOE contractors have even denied workers these documents when Freedom of Information Act requests were submitted, saying that the dose results were contractor work product and were confidential information that could not be provided to the worker. Access to this information if it is attained is often many months after the intake and the reports may not be finalized until many months after the intake.

Many former INL workers may suspect that they have been exposed to radiation or chemicals and following illness may have applied to the Energy Employee Occupational Illness Compensation Program Act (EEOICPA) only to be denied. ${ }^{43}$ The National Institute of Occupational Safety and Health (NIOSH) that administers the energy employee illness program, the EEOICPA, emphasizes that it uses claimant favorable modeling to determine whether working at INL likely caused the illness. But they have denied two-thirds of the claims by INL workers. Fortunately, there are now several radiation exposure cohorts that provide

compensation for INL and ANL-W employees for certain years of employment without requiring radiation dose reconstruction to determine eligibility.

NIOSH decides whether to approve or deny claims but has never taken a look at the drinking water contamination levels at various INL sites. If they had, they would have needed to fill-inthe-blanks on the contamination levels for the years that various contaminants were present but not monitored. No such report exists. Environmental Defense Institute has prepared two reports, however, that highlight some of the recorded levels of contamination in drinking water at INL and downgradient of the INL. 4546

NIOSH did, however, conduct epidemiology comparing the health of INL workers to that of surrounding communities and they found that both radiation workers and non-radiation workers at the INL site had elevated illnesses. ${ }^{47}$ NIOSH never sought to answer why.

432 USC 7384, The Act--Energy Emplovees Occupational Illness Compensation Propram Act of 2000
(EDOICPA). as Amended and see the website for the Center for Disease Control, National Institute of (EEOICPA), as Amended and see the website for the Center for Disease Control, Nat

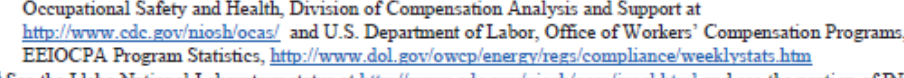
44 See the Idaho National Laboratory status at httrp://www.cdc. gov/niosh/ocas/ineel.hthl and see the portion of NI formerly ANL-W at http://Www.cdc. goviniosh/ocas/anlw. html

Environmental Defense Institute report by Tami Thatcher, The Hidden Truth About INL Drinking Water, June

2015, http://environmental-defense-institute. or g publications/INL drinkwaterR1.pde

t $800 \mathrm{pCi} / \mathrm{L}$ in the Snake River Plain Aquifer in the Magic Valley at Kimama: Why This Matters, 2017. wurwsenvironmental-defense-

"An Epidemiology Study of Mortality and Radiation-Related Risk of Cancer Among Workers at the Idaho
National Engineering and Environmental Laboratory, a U.S. Department of Energy Facility, January 2005 .
The information in this report, unfortunately, is not likely to help these non-radiation workers or radiation workers obtain energy employee illness compensation because, officially, many of these workers have little or no record of significant radiation exposure and may not have been assigned a radiation badge. And this is despite the growing body of human epidemiological evidence that shows that the officially accepted models of radiation cancer risk underestimate the evidence that shows that the of
harm of ionizing radiation. 4849

I gave public comment at the October meeting of the INL Citizens Advisory Board to update CAB members on the November 8, 2011 plutonium plate inspection accident at the INL's Materials and Fuels Complex. ${ }^{50}$ Meeting minutes from 2011 document how the CAB had been assured that the radiation doses from the accident were so low that no worker would be restricted from returning to radiation work. ${ }^{51}$

But more than one worker was restricted from radiation work for months. And bioassay at eight months still showed elevated plutonium and americium excretion. ${ }^{52}$ Bioassay results and other details of their radiation dose estimates were withheld from workers.

Several MFC workers were affected by a subsequent americium inhalation event in 2014 involving a different process. http://www.cdc.gov/niosh/docs/2005-131/pdf/2005-131.pdf and h/ttp://wwww.edc.gov/niosh/oerp/ineel.htm and ${ }^{48}$ Richardson, David B., et al., "Risk of cancer from occupational expossure to ionizing radiation: retrospective cohort study of workers in France, the United Kingdom, and the United States (INWORKS), BMJ, v. 351

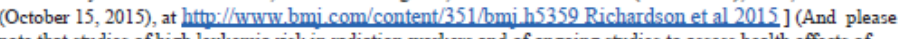

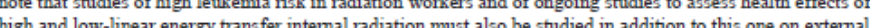
high and lo
radiation.)

49 "Health Risks from Exposure to Low Levels of Ionizing Radiation BEIR VII - Phase 2, The National Academies Press, 2006, htttp://www nap.edu/catalog.php? Trecord id=11340 The BEIR VIII report reaffirmed the conclusion of the pnor report that every exposure to radiation produces a corresponding increase in cancer risk. The BEIR VII report found increased sensinvity to radiation in children and women. Cancer nskk incidence figures for solid tumors for women are about double those for men. And the same radiation in the first year of
life for boys produces three to four times the cancer risk as exposure between the ages of 20 and 50 . Female infants have almost double the risk as male infants.

${ }^{50}$ U.S. Department of Energy Office of Health, Safety and Security Accident Investigation Report, "Plutonium contamination in the Zero Power Physics Reactor Facility at the Idaho National Laboratory, November 8,

2011," January 2012.
${ }^{51}$ Idaho National Laboratory Citizens Advisory Board, meeting minute archive for November 2011 at

${ }_{52}$ Private communication with radiation worker 2012 through 2015 , witness of NIOSH data capture intervie regarding the ZPPR dose analysis in 2014 and access to NL's 'Dose Assessments for November 8, 2011 ZPPR Evenf" with redactions, INL/NT-12-27269, September 2012.

${ }^{53}$ Department of Energy Occurence Report NE-ID-BEA - - FMF - 2014- 0001. 'MFC-704 FMF Suspect Contamination Found on CAM Filters," Sept 24, 2014. "On October 9, 2014, it was reported that low levels of transuranic contamination were detected on four separate filters, two each taken from a Continuous Air Monitor 25 through September 2 Multiple workers were found, weeks later, to have internal contamination as determined by bioassay. Battelle Energy Alliance wrote in the occurrence report that no cause analysis of the undetected elevated levels of arborme contamination was needed. 
Table A-2. DOE's response to comments on the draft EA sorted by commenter.

\section{Nuclear Energy is Not Affordable}

The EA asserts that nuclear energy is affordable but with no basis. It is a simple sharing of an untrue myth, typical of much of the baseless assertions in the EA. Despite enormous federal

taxpayer subsidies of nuclear energy, it remains one of the most expensive sources of electricity and recent bailout requests and two partially constructed AP1000 plants in S. Carolina have been abandoned, at great expense to rate payers.

The pre-renaissance claim around 2006 that the nuclear industry knew how to control construction costs has not panned out. It will have rate payers paying higher power bills for decades without any energy generation from the abandoned South Carolina plants unless legal actions succeed in protecting ratepayers from the ballooning costs. Ratepayers in Georgia are paying a surcharge for the plants despite no power being generated by the plants.

The Westinghouse Nuclear Division bankruptcy filing last March because of the cost overruns the billions on the fixed-cost contract for construction of the four US plants, two at South Carolina's Summer station and two at Georgia's Plant Vogtle. ${ }^{54}$ Westinghouse was bought by Japan's Toshiba in 2006 with hopes of a nuclear renaissance in the US. Toshiba has announced that it has no further plans to compete to build nuclear plants. Toshiba will be paying out $\$ 2.2$ billion to $\$$. Carolina, and $\$ 3.7$ billion to Georgia to extricate itself from the fiasco.

The Westinghouse nuclear website still claims to have designed a safer and simplified plant that because of modern, modular-construction techniques that would shorten construction times and improve quality. It claims that the AP1000 was designed to be economically competitive with contemporary fossil-fueled plants. ${ }^{56} \mathrm{Claiming}$ nuclear energy to be reliable, safe, and affordable nuclear power doesn't pass the snicker test anymore, so the nuclear promoters are claiming that commercial nuclear reactors are needed for national security.

Now that Westinghouse is bankrupt, it joins the ranks of other nuclear builders that have exited the nuclear reactor business. France's Areva has been bailed out by France but remains swamped by the currently unfinished EPR plant in Finland that has large cost overruns and delays. Japan's GE Hitachi never found a buyer for its sodium cooled reactor based in the INL Experiment

Breeder Reactor II (EBR-II) design. Other companies including Germany's Siemans have left the nuclear reactor construction industry. ${ }^{58}$

${ }^{4}$ Russell Grantham and Johnny Edwards, The Attlanta Journal-Constitution, "Plant Vogtle: Georgia's nuclear

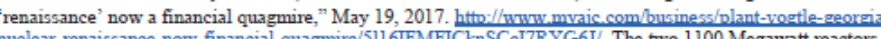
were to have powered 1.5 million homes, cost $\$ 14$ billion, and been running in 2016

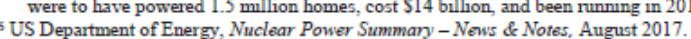

https://wwww.energy-gov//sites//prod/files/2017/08/f35/Nuclear-Power-Summary-August-2017 0.pdf

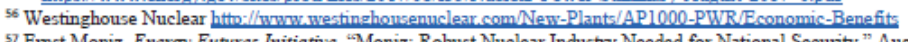

Emst Moniz, Energy Futures Initiative, "Moniz: Robust Nuclear Industy Needed for National Security," Augu

17, 2017. https://www nei. org/News-Media/News/News-Archives/2017Moniz-Robust-Nuclear-Industry-

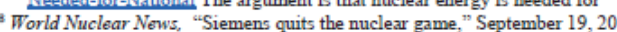

news org/C Siemens guits the muclear game 1909111 .htuml "The head of German industrial giant Sieme

has said the company will withdraw its remaining nuclear power offerings and leave the industry."
DOE Continues Shallow Burial of Long-lived and Mobile Radionuclides Over the Aquifer

The EA briefly mentions the Remote Handled Low-Level Waste disposal facility at the Idaho National Laboratory but fails to discuss that this includes Greater-Than-Class-C long-lived radionuclides that are expected to migrate into the Snake River Plain aquifer. The computations to provide the Performance Assessment for the rate at which the radionuclides will migrate into the aquifer are based on unsupported assumptions regarding optimistic selection of properties to slow the estimated rate of migration, assumption of uniform mixing in the aquifer while ignoring the known presence of "fast paths," the presumed lack of flooding, and stable geology for the need million and more years. The EA fails to mention have the DOE hopes to increase the amount of radionuclides buried over the aquifer without so much as even the pretense of a soil cap to slow the migration of radionuclides into the aquifer. The EA obscures the fact that the DOE continues to bury radioactive waste over our Snake River Plain aquifer. ${ }^{59}$ The DOE has failed to be truthful about past aquifer contamination migration to the south of the Idaho National Laboratory, as I describe in Tritium at $800 \mathrm{pCi} / \mathrm{L}$ in the Snake River Plain Aquifer in the Magic Valley at Kimama: Why This Matters. ${ }^{60}$

The INL appears to being ignoring the transport of radionuclides from buried waste to the surface by upward diffusion through the unsaturated soils. In an EA for shallow burial of the nation's entire GTCC inventory at the Andrews, Texas WCS facility, ${ }^{61}$ that EA found that burial of GTCC waste at the WCS facility, at the Andrews County, Texas waste site would be dominated by upward diffusion of volatile radionuclides. This means the estimates of air emissions may be omitting this contribution for INL air emissions.

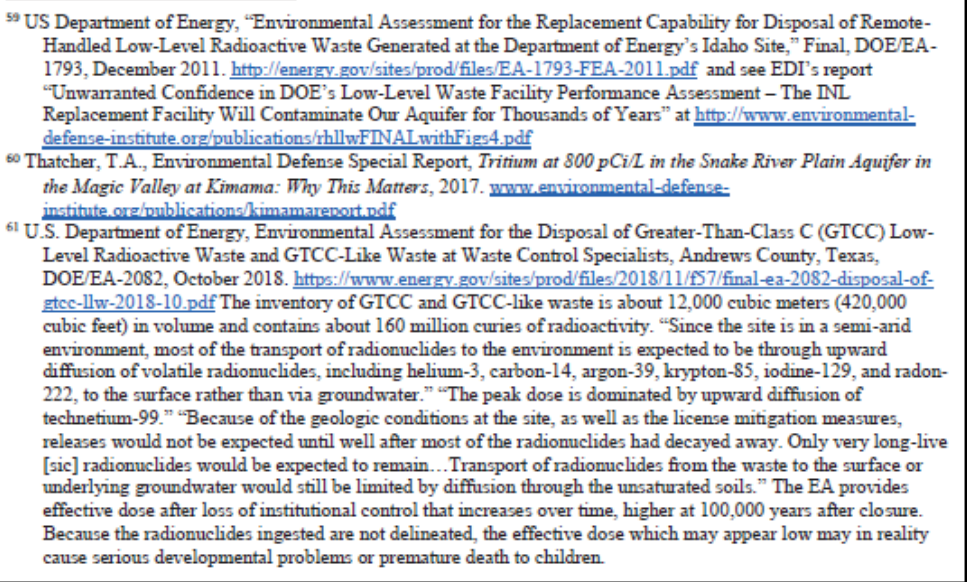


Table A-2. DOE's response to comments on the draft EA sorted by commenter.

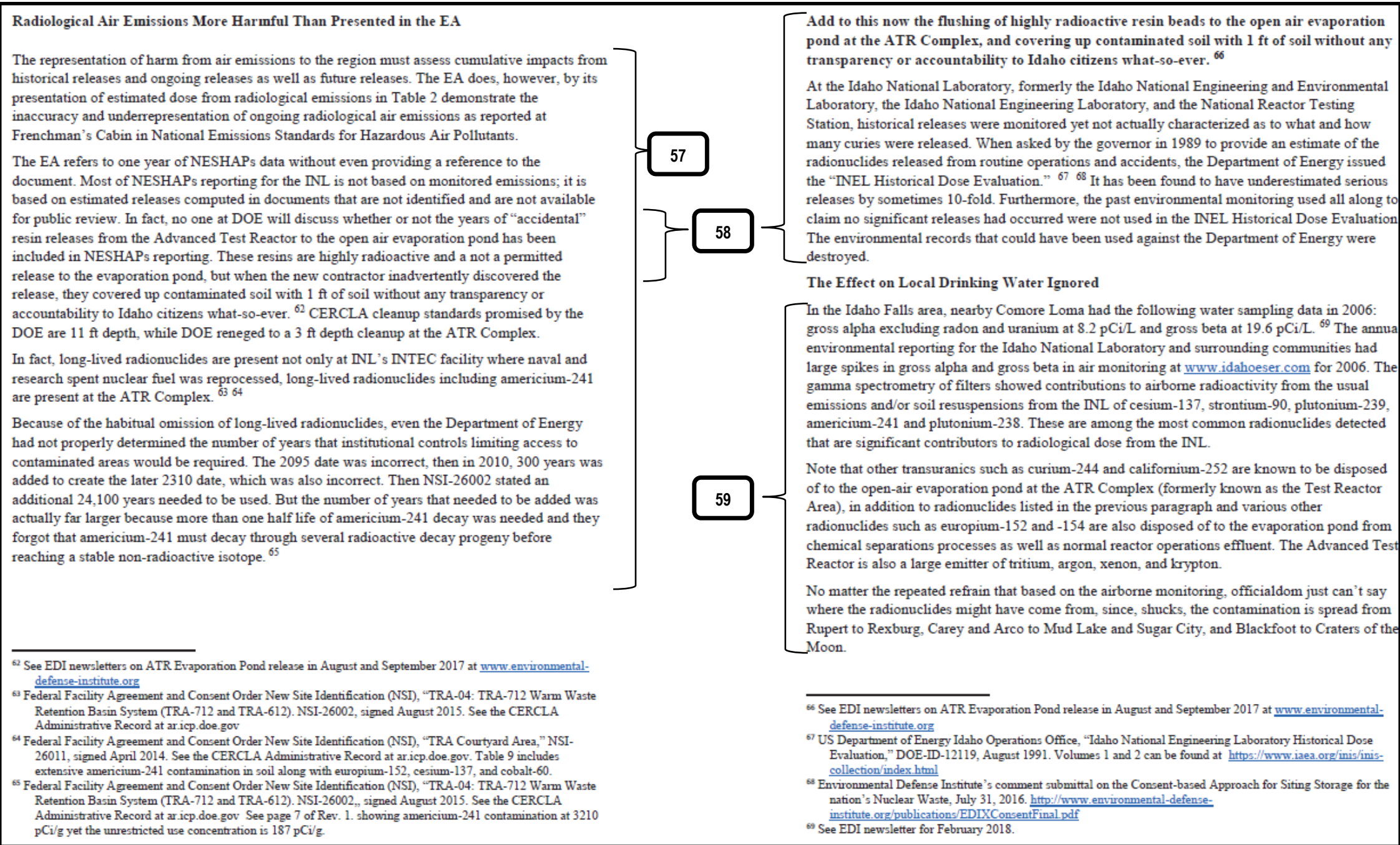


Table A-2. DOE's response to comments on the draft EA sorted by commenter.

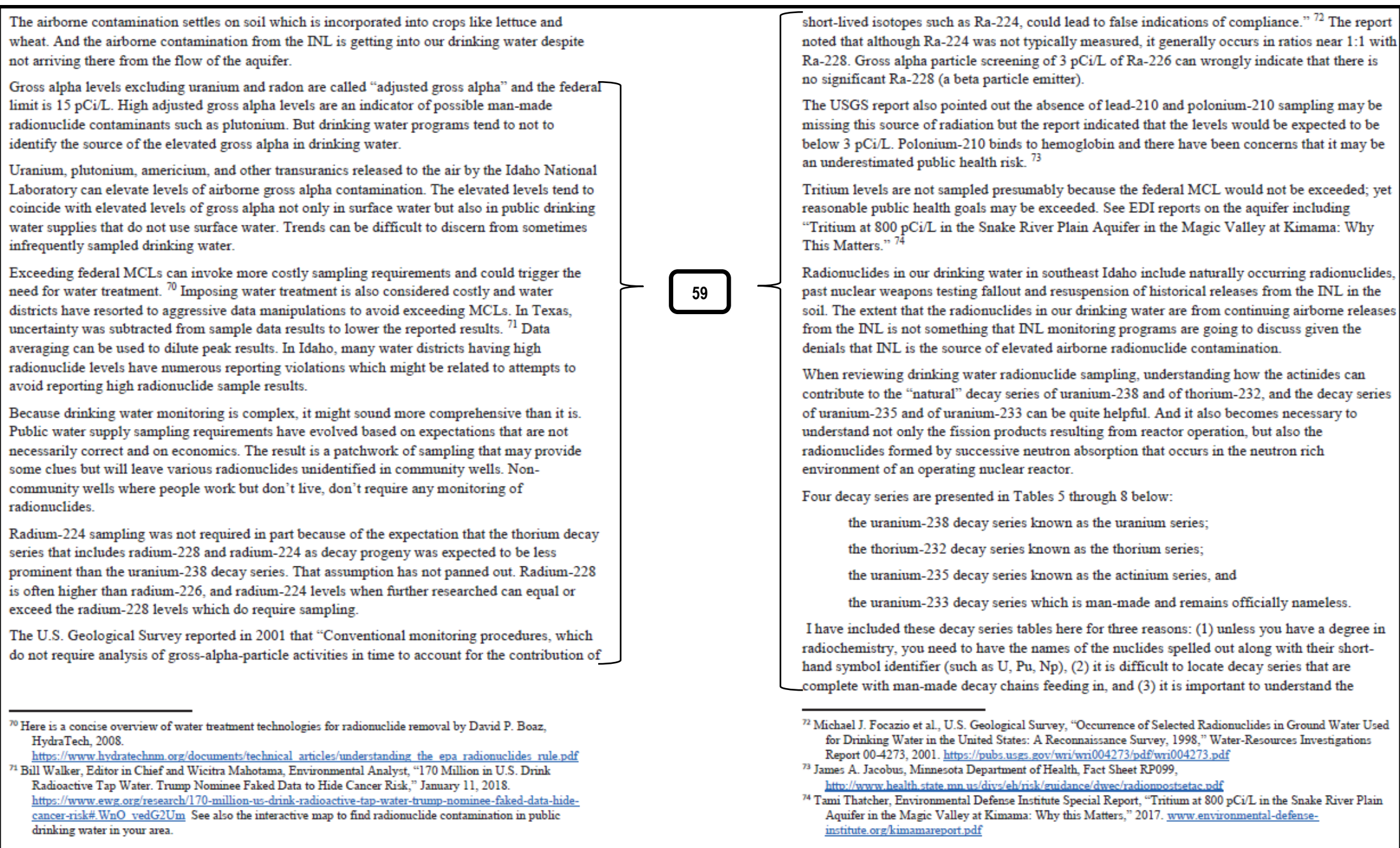


Table A-2. DOE's response to comments on the draft EA sorted by commenter.

specific decay series that a radionuclide belongs to as you study drinking water, lung count results and environmental radionuclide emissions data.

These decay series show the man-made actinides that may also decay through the same series in grey. The decay series depict alpha decay as progressing downward and reducing the atomic mass by 4 . Beta decay by electron emission is depicted as progressing upward diagonally to the right. Beta decay flips a neutron into a proton and stays at the same atomic mass. Isotopes of the same chemical element have the same number of protons but can have variable numbers of neutrons and variable atomic mass. The half-lives of the various radionuclides range from millions or billions of years to milli-seconds.

Along with alpha and beta decays at various energy levels, gamma photon emissions of various energy levels can also occur which can be detected by gamma spectrometry.

So, while uranium, thorium and plutonium are thought of primarily as alpha particle emitters, gamma radiation is also emitted and decay progeny may emit beta particles rather than alpha particles along with gamma radiation at various energy levels measured in kiloelectron volts $(\mathrm{keV})$.

Weak or low energy gamma emissions require less shielding than higher energy gamma emissions. Uranium decay progeny of Th-231, Th-234 and Pa-234, all beta emitters, have high specific activity in curies per gram that require some protection of workers.

Sources of uranium-238 include natural soil and rock sources, mill tailings, depleted uranium, reactor fuel melting from reactor accidents, and spent fuel reprocessing. Sources of uranium-23 decay progeny can include man-made plutonium-238 that is present in various materials and processes at the INL.

Sources of thorium-232 include natural thorium-232 in rock and soil. Sources of thorium-232 can also include man-made plutonium-240 and uranium-236 resulting from neutron capture in a reactor

Sources of uranium-235 include natural uranium in rock and soil but are typically considered to be of small enough abundance to be ignored. But this decay series should not be ignored where enriched uranium is released to the environment. Sources of the U- 235 decay series also include plutonium-239 which decays to uranium-235. Dispersion of reactor fuel from reactor accidents and spent fuel reprocessing can spread uranium-235 in the environment. Waste water disposal from HEU spent fuel reprocessing has put uranium-236 in the Snake River Plain Aquifer. Fuel reprocessing and calcining and reactor fuel melt tests or accidents spread various radionuclides present in nuclear fuels to air and soil.
Table 5. Uranium-238 decay series.

\begin{tabular}{|l|c|c|c|l|l|l|l|}
\hline Califomium & $\mathrm{Cf}-250^{*}$ & & & & & & \\
\hline Curium & $\mathrm{Cm}-246^{*}$ & & $\mathrm{Cm}-242$ & & & & \\
\hline Americium & $\downarrow$ & $\mathrm{Am}-242 /$ & $\downarrow$ & & & & \\
\hline Plutonium & $\mathrm{Pu}-242$ & $\downarrow$ & $\mathrm{Pu}-238$ & & & & \\
\hline Neptunium & $\downarrow$ & $\mathrm{Np}-238 /$ & $\downarrow$ & & & & \\
\hline Uranium & $\mathrm{U}-238$ & & $\mathrm{U}-234$ & & & & \\
\hline Protactinum & $\downarrow$ & $\mathrm{Pa}-234 /$ & $\downarrow$ & & & & \\
\hline Thorium & $\mathrm{Th}-234 /$ & & $\mathrm{Th}-230$ & & & & \\
\hline Radium & & & $\mathrm{Ra}-226$ & & & & \\
\hline Radon & & & $\mathrm{Rn}-222$ & & & & \\
\hline Polonium & & & $\mathrm{Po}-218$ & & $\mathrm{Po}-214$ & & Po-210 \\
\hline Bismuth & & & $\downarrow$ & $\mathrm{Bi}-214 /$ & $\downarrow$ & $\mathrm{Bi}-210 /$ & $\downarrow$ \\
\hline Lead & & & $\mathrm{Pb}-214 /$ & & $\mathrm{Pb}-210 /$ & & $\begin{array}{l}\text { Pb-206 } \\
\text { (stable) }\end{array}$ \\
\hline
\end{tabular}

Lead (stable) Table notes: Alpha decay downward reduces the atomic mass by 4; beta decay upward diagorl
neutron to a proton and stays at the came atomic mass. In the table, anrow symbols downward are used to show the progression of some alpha decays if there was space to show the arrow. Movement upward and to the right is shown by/ which is a lame keyboard attempt to look like an arrow. Man-made actimides are shown in grey.

Decay series to CF.250 and Cm.246 Sources of wanium-2ss include natural soil and rock sources, depleted uranium, reactor fuel melting from $r$

Table 6. Thorium-232 decay series.

\begin{tabular}{|c|c|c|c|c|c|c|c|}
\hline Califomium & $\mathrm{Cm}-252$ & & Cf-248 & & & & \\
\hline Curium & $\mathrm{Cm}-248$ & & $\mathrm{Cm}-244$ & & & & \\
\hline Americium & & & & & & & \\
\hline $\begin{array}{l}\text { Plutonium } \\
\end{array}$ & Pu-244 & & Pu-240 & & & & \\
\hline Neptunium & & $\overline{\mathrm{Np}-240 /}$ & & & & & \\
\hline Uranium & U-240 & & U-236 & & & & \\
\hline Protactinium & & & $\downarrow$ & & & & \\
\hline Thorium & & & Th-232 & & \begin{tabular}{|l|} 
Th-228 \\
\end{tabular} & & \\
\hline Actinium & & & $\downarrow$ & $\mathrm{Ac}-228 /$ & & & \\
\hline Radium & & & Ra-228/ & & Ra-224 & & \\
\hline Radon & & & & & $R n-220$ & & \\
\hline Polonium & & & & & Po-216 & & $\begin{array}{l}\text { Po-212 } \\
\end{array}$ \\
\hline Bismuth & & & & & 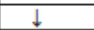 & $\mathrm{Bi}-212 \gamma^{\circ}$ & \\
\hline Lead & & & & & $\mathrm{Pb}-212 /$ & $\downarrow$ & 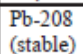 \\
\hline Thallium & & & & & & \begin{tabular}{|l|}
$\mathrm{Tl}-208 /$ \\
\end{tabular} & \\
\hline
\end{tabular}

\begin{tabular}{|l|l|l|l|l|}
\hline Thallium & & & & Tl-208/ \\
See table notes for Table 5. Sources of thorium-232 include natural thorium-232 in rock and soil. Plutonium-240 and
\end{tabular} uranium-236 which results from neutron capture in a reactor also decay to thorium-232. Depleted wranium can include uranium-236. The higher actinides that decay to plutonium -240
and -248 , curium-248 and -244 , plutonium-244, and neptunium-240. 
Table A-2. DOE's response to comments on the draft EA sorted by commenter.

\begin{tabular}{|c|c|c|c|c|c|c|c|c|c|}
\hline \begin{tabular}{|l|} 
Californium \\
\end{tabular} & Cf-251 & & & & & & & & \\
\hline \begin{tabular}{|l|} 
Berkelium \\
\end{tabular} & & Bk-247 & & & & & & & \\
\hline \begin{tabular}{|l|l|} 
Curium \\
\end{tabular} & $\mathrm{Cm}-247$ & $\downarrow$ & $\mathrm{Cm}-243$ & & & & & & \\
\hline \begin{tabular}{|l} 
Americium \\
\end{tabular} & & $\mathrm{Am}-243$ & & & & & & & \\
\hline \begin{tabular}{|l|} 
Plutonium \\
\end{tabular} & $\mathrm{Pu}-243 /$ & & Pu-239 & & & & & & \\
\hline \begin{tabular}{|l} 
Neptunium \\
\end{tabular} & & $\mathrm{Np}-239 /$ & & & & & & & \\
\hline \begin{tabular}{|l|} 
Uranium \\
\end{tabular} & & & U-235 & & & & & & \\
\hline \begin{tabular}{|l|} 
Protactinium \\
\end{tabular} & & & & $\mathrm{Pa}-2$ & & & & & \\
\hline \begin{tabular}{|l|} 
Thorium \\
\end{tabular} & & & Th-231/ & $\downarrow$ & & \begin{tabular}{|l|l} 
Th-2 \\
\end{tabular} & & & \\
\hline \begin{tabular}{|l|} 
Actinium \\
\end{tabular} & & & & & $227 r$ & $\downarrow$ & & & \\
\hline \begin{tabular}{|l|l|} 
Radium \\
\end{tabular} & & & & & & Ra-2 & 223 & & \\
\hline \begin{tabular}{|l|} 
Francium \\
\end{tabular} & & & & & $23 / 4$ & $\downarrow$ & & & \\
\hline \begin{tabular}{|l|} 
Radon \\
\end{tabular} & & & & & & Rn-2 & & & \\
\hline \begin{tabular}{|l} 
Polonium \\
\end{tabular} & & & & & & Po-2 & & & \\
\hline Bismuth & & & & & & $\downarrow$ & & Bi-211/ & \\
\hline \begin{tabular}{|l} 
Lead \\
\end{tabular} & & & & & & & $211 /$ & & $\begin{array}{l}\mathrm{Pb}-207 \\
\text { (stable) }\end{array}$ \\
\hline \multirow{2}{*}{\multicolumn{10}{|c|}{$\begin{array}{l}\text { See table notes for Table } 5 \text {. Sources of wranium-235 include natural wranium in rock and soil. It should not be } \\
\text { ignored where enriched uranium is released to the environment. Plutonium-239 also decays to wanium-235 and } \\
\text { higher actinides (califonium, curium, americium and neptunium) are shown. Dispersion of reactor fuel from reactor } \\
\text { accidents and spent fuel reprocessing can spread uranium-235 in the enviromment. }\end{array}$}} \\
\hline & & & & & & & & & \\
\hline \multirow{2}{*}{\multicolumn{10}{|c|}{ Table 8. Uranium-233 decay series. }} \\
\hline \begin{tabular}{|l|} 
Californium \\
\end{tabular} & & & & & & & & & \\
\hline \begin{tabular}{|l|} 
Curium \\
\end{tabular} & $\mathrm{Cm}-245$ & & & & & & & & \\
\hline \begin{tabular}{|l} 
Americium \\
\end{tabular} & & Am-241 & & & & & & & \\
\hline \begin{tabular}{|l} 
Plutonium \\
\end{tabular} & $\mathrm{Pu}-241 /$ & & & & & & & & \\
\hline \begin{tabular}{|l|} 
Neptunium \\
\end{tabular} & & Np-237 & & & & & & & \\
\hline \begin{tabular}{|l|} 
Uranium \\
\end{tabular} & & & U-233 & & & & & & \\
\hline \begin{tabular}{|l|} 
Protactinium \\
\end{tabular} & & $\mathrm{Pa}-233 /$ & & & & & & & \\
\hline \begin{tabular}{|l|} 
Thorium \\
\end{tabular} & & & Th-229 & & & & & & \\
\hline \begin{tabular}{|l|l|} 
Actinium \\
\end{tabular} & & & & & $\mathrm{Ac}-2$ & & & & \\
\hline \begin{tabular}{|l|} 
Radium \\
\end{tabular} & & & Ra-225/ & & & & & & \\
\hline \begin{tabular}{|l} 
Francium \\
\end{tabular} & & & & & $\mathrm{Fr}-22$ & & & & \\
\hline \begin{tabular}{|l} 
Radon \\
\end{tabular} & & & & & & & & & \\
\hline \begin{tabular}{|l|} 
Astatine \\
\end{tabular} & & & & & At-21. & & & & \\
\hline \begin{tabular}{|l|l|} 
Polonium \\
\end{tabular} & & & & & & & Po-2 & & \\
\hline \begin{tabular}{|l} 
Bismuth \\
\end{tabular} & & & & & $B i-21$ & & & & ii-209 \\
\hline \begin{tabular}{|l|} 
Lead \\
\end{tabular} & & & & & & & $\mathrm{Pb}-2$ & & \\
\hline \begin{tabular}{|l|l|l|l} 
Thallium \\
\end{tabular} & & & & & & & & & $1-205$ \\
\hline
\end{tabular}

See table notes for Table 5 . Uranium- -233 is not naturally occuning. This weapons físsile material can only be
produced in a reactor or by the hiyher actinide decays shown including plutonium- 241 and americium- 241 decay

produced in a reactor or by the higher actinide decays shown including plutonium -241 and amencium- 241 decay.
Higher actinides (californium, curium, americium and neptunium) are shown. Uranium -233 can and has been used
in nuclear weapons testing. It dispersion can also result from vanious weapons production and separations

in nuclear weapons testing. Its dispersion can also result from various weapons production and separations
processes. Disposal of americium-24l following plutonium purification may be a sigmificant source. It can also

result from spent fuel reprocessing particularly of high enriched uranium fuel because of the high buildup of

neptunium-237 in HEU reactor operations.

Depleted uranium is uranium that is left over after extraction of uranium-235. Enriched uranium includes more than 0.72 percent up to 93.5 percent U- 235 enrichment. Commercial nuclear

power reactors typically use 3 to 5 percent enrichment. Enriched uranium also includes increased amounts of uranium-234 which cannot be separated from the uranium-235. Most depleted

uranium includes between 0.2 and 0.4 percent uranium-235. Depleted uranium composition can vary and can include uranium- 236 if it resulted from reactor fuel reprocessing. The health harm caused by inhalation or ingestion of depleted uranium includes illness and increased risk of birth defects. ${ }^{75}$

Uranium-233 is not naturally occurring. This weapons fissile material can only be produced in a reactor or by the higher actinide decays shown including plutonium-241 and americium-241 decay. Uranium- 233 has been dispersed by its production, separation and limited use in nuclear weapons testing. Disposal of americium-241 following plutonium purification may be a significant source. It can also result from spent fuel reprocessing particularly of high enriched uranium fuel because of the high buildup of neptunium-237 in HEU reactor operations.

Higher actinides such as californium, curium, americium and neptunium may be produced using target material in nuclear reactors in order to produce weapons related materials or to produce a heat source for radiothermal generators such as plutonium-238 which is used as a power supply in spacecraft. ${ }^{77}$ These materials have been disposed of routinely to an open-air evaporation pond at the INL's ATR Complex. These materials have not necessarily been included in required federal reporting under the National Emissions Standards (NESHAPs) because they are not monitored but only estimated. Therefore, whenever unplanned releases are occurring via escaping resin beads, for example, the emissions would be underestimated. Frankly, the NESHAPs reporting by the INL appears to lack validation and may substantially understate INL's airborne emissions of transuranics and other radionuclides.

The environmental monitoring of airborne radioactivity that is conducted tends to ignore peaks and appears to be missing weeks of data in graphs charting alpha and gamma airborne radiation levels. This can be observed for various years, but is particularly obvious in $2006 .{ }^{78}$ Particulate matter in filters for 2006 provide instances of elevated levels of radionuclides such as plutonium-

${ }^{75}$ Rosalie Bertell, Intemational Journal of Health Services, "Depleted Uranium: All the Questions About DU and Gulf War Syndrome Are Not Yet Answered," 2006. p. 514

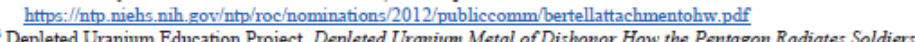
\& Civilians with DU Wreapons, 1997 ISBN:0-9656916-0.8

${ }^{77}$ Transuranics are radionuclides often having extremely long half-lifes. Many decay progeny may be created before reaching a stable, non-radioactive state. See our factsheet at $h$ http://wwww. environmental-defenseinstitute. org'publications/decavfact.pdf. See also an ANL factsheet at hhtps://wwwremm nlmgov/ANL.

${ }^{7}$ Annual and quarterly environmental monitoring reports of the Idaho National Laboratory and surrounding Energy funded and overseen Idaho National Laboratory Site Environmental Surveillance, Education, and Research Program Some charts are edited to reduce clarity but charts using raw data show significant gaps in monitoring airbome gross alpha and gross beta the graphs available by community. 
Table A-2. DOE's response to comments on the draft EA sorted by commenter.

239, plutonium-238 and americium-241 in the filters along with cesium-137 and strontium-90. A high statistical bar allows denial that a "detection" of the radionuclide occurred.

Numerous "detections" were admitted in assessing filter particulate in 2006, see first quarter 2006 air monitoring at www.idahoeser.com. ${ }^{79}$

The coincidence of elevated levels of airborne radioactivity seem to correspond to elevated gross alpha and gross beta levels in drinking water monitoring.

Weapons material that is fissile include uranium- 235 which is concentrated by enrichment while plutonium- 239 is created from uranium- 238 by neutron capture in a nuclear reactor. Fission

products such as cesium-137 and strontium-90 (and many others) are created in a nuclear reactor by the splitting apart of uranium atoms. Actinides are created by neutron capture and these

include the actinides neptunium, plutonium, americium, curium and californium.

As shown in the decay series tables, man-made actinides can decay to "natural" decay series. But natural does not mean healthy especially when the levels of decay progeny are elevated. And the experts that pretend that the decay progeny are from "natural" background are not admitting that the reason the levels of decay progeny are elevated is due to the release of radionuclides from the INL and other nuclear operations.

Many of these decay progeny are harmful to health but are not monitored because of the techniques used to perform sampling or due to a mistaken belief that since uranium is natural it does not need to be monitored. Uranium health effects depend on the solubility and the concentration and health studies of miners are not necessarily exposed to comparable chemical forms of uranium.

Uranium, including depleted uranium, persists in the environment essentially forever and causes illness, cancer and increased risk of birth defects. Gulf war veterans found this out as their babies were born with missing fingers and arms. See our 2017 EDI report about radiological and chemical exposures at the INL. $\$$

\section{EA Ignores Genetic Consequences of Radionuclide Emissions}

Anyone who has ever been a radiation worker in the US has been told repeatedly that, despite the known genetic damage to fruit flies from radiation exposure, no genetic consequences have every been documented in humans. Well, Plutopia documents the elevated percentage of dea among infants in the Richland population in the 1950s. Elevated fetal deaths and birth defects in Richland were documented by the state health reports, yet Hanford's General Electric doctors and the Atomic Energy Commission that later became the Department of Energy failed to point these statistics out. The local newspapers failed to write of it. The Department of Energy has

${ }^{7}$ Annual and quarterly environmental monitoring reports of the Idaho National Laboratory and surounding

communities hatte://Wwwwidahoesercom/Publications surveillance htm

Tami Thatcher, Envirommental Defense Institute, Radiological and Chemical Exposures at the INL That Workers May Not Have Known About, April 2017. http:///www.environmental-defenseinstitute. orepublications/Radchemreport.pdf continued to fail to tell radiation workers and the public of the known risk of increased infant mortality and increased risk of birth defects that result from radiation exposure.

The finding of excess infant deaths near the Department of Energy Savannah River site aroun the 1970s and near the 1979 Three Mile Island nuclear accident are described in Jay Gould's book Deadly Deceit. ${ }^{81}$ But I was unaware of the clarity of the records of infant mortality in the case of Richland near Hanford. The disregard to human life and human suffering seems to go hand-in-hand with the nuclear industry. But you don't have to take my word for it - read and know the history for yourself

The Department of Energy support for and subsequent squelching of Hanford radiation worker epidemiology studies are described in Gayle Greene's The Woman Who Knew Too Much - Alice Stewart and the Secrets of Radiation. ${ }^{82}$ Alice Stewart is famous for the unexpected finding that very small external $\mathrm{x}$-ray medical radiation doses to pregnant woman in the $1950 \mathrm{~s}$ increased the risk of childhood cancer and leukemia.

Time magazine recently mentioned Julian Aguon's book What We Bury At Night, a chronicle of how irradiated Marshallese mothers had borne "jellyfish babies" with translucent skin and no bones. From 1946 to 1958 , the U.S. tested 67 nuclear weapons in the Marshall Islands near Guam. Official reports omitted the truth of the birth defects.

For more information about the health effects and after math from the U.S. bomb tests over the Pacific islands and the repeated deceptions about the consequences, read Giff Johnson, Don't

Ever Whisper -Darlene Keju, Pacific Health Pioneer, Champion for Nuclear Survivors. ${ }^{83}$

Summary

For the action proposed in the EA, to make HALEU fuel, to be meaningful, that fuel would need to be utilized. The environmental impacts from the utilization of the fuel have not been included in the EA. Omitted are meaningful and complete air emissions for the Idaho National

Laboratory, not only in terms of radiation dose in units of rem, but including the radionuclides reported at Frenchman's Cabin which obscures the releases from MFC as well as lacking radionuclide contribution to the dose estimate and being generally based on guesses that are not available to the public.

The air and water in our region are constantly bombarded with radiological releases from the INL, and various annual reports through the years indicate that these releases include americium241, plutonium-238, plutonium-239 and other extremely long-lived radionuclides.

${ }^{81}$ Jay M. Gould and Benjamin A. Goldman, Deadly Deceit - Low Lovel Radiation High Level Cover-Up. Four Walls Eight Windows New York, 1990. ISBN 0-941423-35-2

Gayle Greene, The Woman Who Knew Too Much -Alice Stewart and the Secrets of Radiation, University of Michigan, 1999. ISBN 0-472-08783-5.

Giff Johnson, Don't Ever Whisper - Pacific Health Pioneer, Darlene Keju, Champion for Nuclear Survivors, 2013. ISBN-10: 148950906 


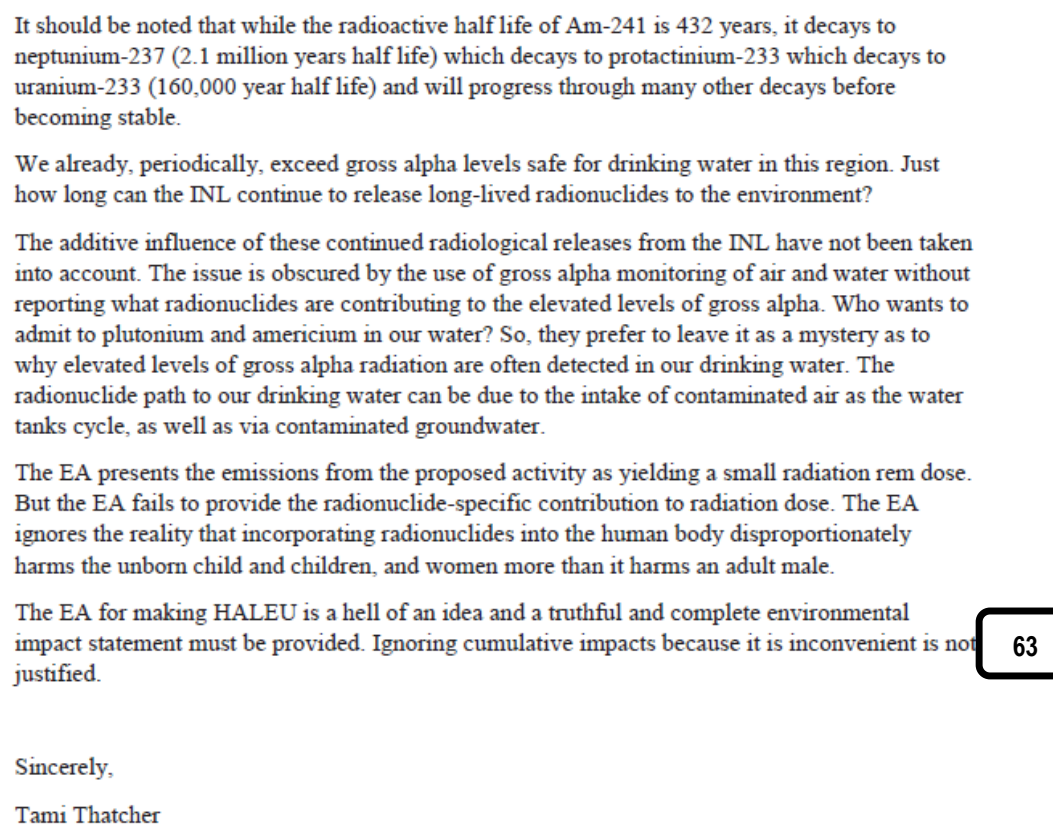

Sincerely,

Tami Thatcher

Response(s) 50 - 63: Ms. Thatcher, thank you for your comments. Please refer to the numbered comments and corresponding numbered responses.

50. The Final Environmental Impact Statement for the Treatment and Management of Sodium-Bonded Spent Nuclear Fuel (DOE/EIS-0306, 2000) discussed the EMT process, but the ROD did not make a decision on the disposition or use of the HALEU product from the EMT process. This EA addresses the HALEU product as HALEU feedstock in production of HALEU fuel.

In accordance with the NEPA implementing regulations, a federal agency can prepare an EA at any time for a proposed action. If potential significant environmental impacts are identified, an EIS can always be pursued. Conversely, if no significant environmental impacts are identified, the EA is the appropriate level of documentation and no further evaluation is necessary. DOE ensures the level and quality of analysis and data compiled for the EA is suitable for use in an EIS if it is decided that an EIS should be prepared. This course of action is appropriate for use when an agency has a basis for the belief that the proposal will not manifest significant environmental impacts.

51. DOE added conversions for pounds ( $\mathrm{lb})$ to kilograms $(\mathrm{kg})$ and $\mathrm{kg}$ to $\mathrm{lb}$. and noted that $1000 \mathrm{~kg}$ equals a MT in the EA sections for helpful information for readers.

52. Treatment of sodium-bonded spent nuclear fuel is ongoing and addressed in the Final Environmental Impact Statement for the Treatment and Management of Sodium-Bonded Spent Nuclear Fuel (DOE/EIS-0306). The proposed action in this EA intends to use the HALEU product from the EMT process addressed in EIS-0306. Idaho Settlement Agreement milestones and management of high-level waste is not part of the scope and analysis of this EA. 
Table A-2. DOE's response to comments on the draft EA sorted by commenter.

53. DOE takes its responsibility for the safety and health of the workers and the public seriously. 10 CFR 830 governs the conduct of DOE contractors, DOE personnel, and other persons conducting activities that affect, or may affect, the safety of DOE nuclear facilities, and DOE holds all personnel acting on its behalf to comply with 10 CFR 830 . When an incident arises of failure to follow the safety requirements, DOE takes action to correct the failure and prevent future recurrence, including causal analysis and extent of conditions review.

54. DOE takes its responsibility for the safety and health of the workers seriously. Radiation worker doses at INL are maintained well below limits as required by regulations $-5 \mathrm{rem}(5,000 \mathrm{mrem})$ whole body deep-dose equivalent per year (10 CFR Part 20). The regulatory limit is based on recommendations provided by the International Commission on Radiation Protection publications and other independent and peer reviewed documents and in consideration of the latest available scientific information of the biology and physics of radiation exposure. Furthermore, in accordance with INL's "as low as reasonably achievable" (ALARA) policy, current administrative control limits (ACL) restrict worker whole body dose to less than $20 \%$ of the regulatory limit.

55. Evaluating nuclear energy's place in the energy market is out of scope of this effort. This EA does not address the economics or affordability of nuclear power, leaving that decision to those proposing to use the HALEU fuel.

\section{See response to comment \#22.}

57. All annual INL radionuclide NESHAP reports are available to the public as well as INL Annual Site Environmental Reports where emissions are presented by radionuclide and facility. Each regulated INL Site facility determines airborne effluent concentrations from its regulated emission sources as required under state and federal regulations. Regarding the assertion in the comment that the "...estimated dose from radiological emissions in Table 2 demonstrate the inaccuracy and underrepresentation of ongoing radiological air emissions as reported at Frenchman's Cabin..." in annual NESHAP reporting, we submit that the opposite is true-that is, the calculated or estimated emissions are greater than measured emissions. The emissions in Table 2 are based on the methodology in 40 CFR 61, Appendix D with EPA approved allowances to account for heating. In the absence of emission measurements, this methodology (or similar) must be used because it results in more conservative emission estimates. In addition, annual INL radiological NESHAP dose calculations and the dose calculations presented in the EA for the HALEU facility are compliant with 40 CFR 61, Subpart H (NESHAP) requirements. This regulation requires the model used to predict dose use a 100-year period for emission, deposition and build-up of radionuclides in soil. It is unlikely that current radiological emission sources at the INL will operate for 100 years, especially the HALEU production facilities which is expected to operate only a few years. The INL Site 2017 NESHAP report DOE/ID-11441 (DOE-ID 2018) was added to the reference list.

58. Commenter surmises that "...radiological emissions in Table 2 demonstrate the inaccuracy and underrepresentation of ongoing radiological air emissions as reported at Frenchman's Cabin..." Radiological emissions from all INL facilities are measured or calculated in accordance with 40 CFR 61 Subpart $H$ "National Emission Standards for Emissions of Radionuclides Other Than Radon from Department of Energy Facilities" (Subpart H - NESHAP) requirements. Emissions from radionuclide emissions sources are required by Subpart $\mathrm{H}$ to be calculated in accordance 40 CFR 61 Appendix D "Methods for Estimating Radionuclide Emissions" or other procedure for which EPA has granted prior approval. These facilities apply the Appendix D airborne emission factors or approved alternate procedures to their respective source terms. The dose from each emission source is modeled using CAP-88 (EPA required air dispersion modeling software) to 62 off-site receptors (residence, school, business, or office). The modeled dose impact from all INL sources at each receptor is summed to determine the highest effective dose equivalent which historically has been at Frenchman's Cabin. Ambient air monitoring performed by DOE's INL Management and Operations (M\&O) contractor; DOE's INL Environmental Surveillance, Education, and Research Program (ESER) contractor (independent from the M\&O contractor); and the Idaho Department of Environmental Quality (DEQ) INL Oversight Program demonstrate that impacts from the INL are low and consistent with the emissions reported in annual INL radionuclide NESHAP reports. DOE contractors' ambient air monitoring data are reported annually in the Annual Site 


\section{Table A-2. DOE's response to comments on the draft EA sorted by commenter.}

Environmental Reports which are available at the ESER program's website. DEQ's INL Oversight Program Annual Reports are available at DEQ's INL Oversight Monitoring Program website.

All discharges to the ATR Complex Evaporation Pond are sampled, reported, and dose modeled in accordance with the facility's air permit and EPA requirements contained in Subpart $\mathrm{H}$ and Appendix D (i.e., the "NESHAP" annual report). This includes any incidental or "accidental" discharges to the evaporation pond. ATR Complex does not purposely flush radioactive resin to the evaporation pond; however, discharges of resin to the evaporation pond are not prohibited by the facility's air permit or Subpart $\mathrm{H}$

Contamination was found outside the contamination area boundary on the berm of the Evaporation Pond fence on the berm of the pond as reported in the 2016 ASER report. In accordance with accepted practices for contaminants at these levels, a soil cap of at least 30 centimeters of soil was added over the area where the contaminants were found. The contaminants were silt-like soils that did not contain any resin. The purpose of the Evaporation Pond permit is to regulate the discharge of radionuclides to the ATR Evaporation Pond. Upon end of useful life of the ATR Evaporation Ponds, the facility would be cleaned up to regulations applicable at the time of closure.

59. The INL manages nine Public Water Systems at the INL Site and provides required sample results to the Idaho Department of Environmental Quality. All of these systems result in water well below those Maximum Contaminant levels identified in the Safe Drinking Water Act.

Potential doses from airborne contamination presented in the EA are based on a long-term chronic exposure scenario for a permanent resident that consumes locally produced food products including crops and vegetables grown in contaminated soil, and milk and meat products from animals that consume contaminated forage. The model used to predict dose also assumes emission, deposition and build-up of radionuclides in soil occurs over a 100-year period-much longer than the operating period assumed in the EA. Doses based on air immersion, direct ground radiation, air inhalation and food ingestion are below all regulatory standards.

Potential impacts of groundwater contamination due to radionuclide deposition on soil and migration to the aquifer have been added to the EA. The source (soil contamination) was conservatively estimated and a screening-level model was used to simulate leaching and transport of radionuclides through the unsaturated zone and in the aquifer. Calculated doses based on maximum predicted groundwater concentrations are well below the doses from air emissions and less than all regulatory limits. DOE added a section on 'Groundwater Exposure Pathway' to the EA (see page 17)

60. Regarding concerns about consequences of potential committed dose to workers, the public, and the environment, the operations proposed under the proposed action would be performed in full compliance with DOE 5400.1, General Environmental Protection Program, DOE Order 458.1, Radiation Protection of the Public and the Environment, and 10 CFR Part 835, Occupational Radiation Protection. Dose based consequences of the proposed action, as detailed in this EA, are derived from the Annals of the ICRP; Publication 103, The 2007 Recommendations of the International Commission or Radiological Protection, and in consideration of the latest available scientific information of the biology and physics of radiation exposure. The purpose of this EA is to assess the environmental impacts of the proposed action.

\section{See response to comment \#12.}

62. Doses in the EA from air emissions are presented at locations where the maximum dose is expected to occur from HALEU production. The current (2017) annual INL NESHAP dose, presented in Table 8, is the dose to the maximally exposed individual (MEI) considering all public receptor locations outside the INL Site boundary where a person is expected to reside. The MEI dose in the NESHAP report is based on the estimated emissions from all radionuclides from all INL 
Table A-2. DOE's response to comments on the draft EA sorted by commenter.

sources. The dose is based on a long-term chronic exposure scenario where the resident lives, works and eats locally produced food products. This dose may change from year to year, but it bounds the dose at any other public receptor location outside the INL for each year. While the INL NESHAP report includes the dose by facility, Annual Site Environmental Reports (ASERs) present the dose at the MEl location by radionuclide and facility.

63. See response to comment \#24

\section{Noy Xayavong, Self}

Comment(s) 64:

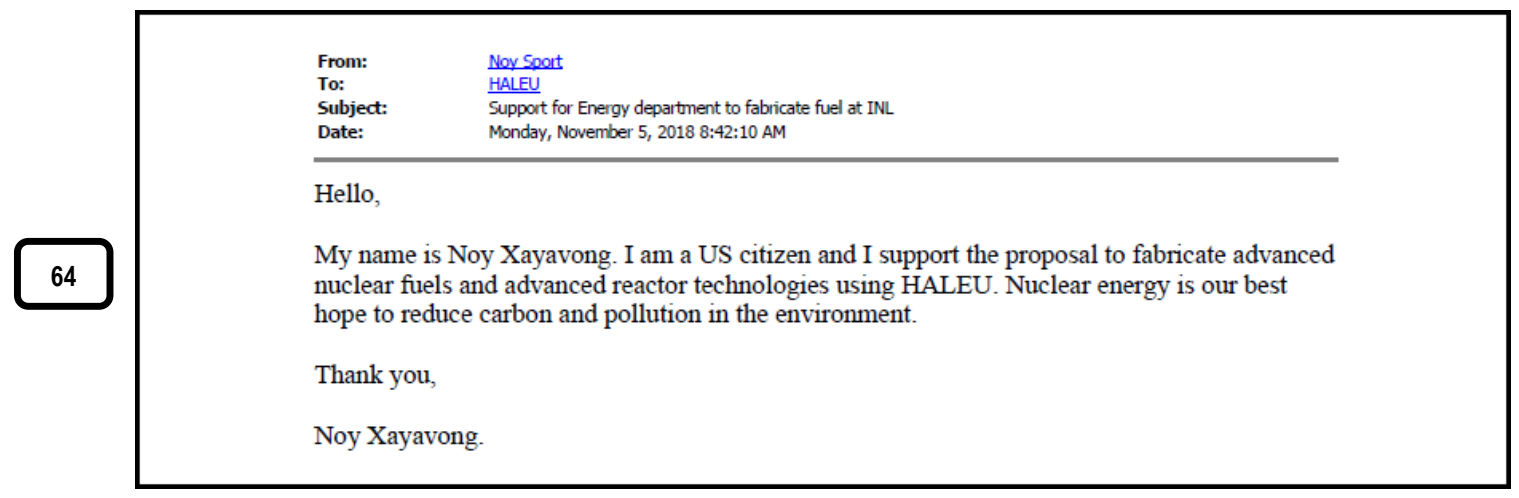

Response(s) 64: Mr. Xayavong, DOE acknowledges your comment supporting the proposed action. Thank you. 